\title{
Human hepatocellular membrane antigens : studies on PLC/PRF/5 cells
}

Citation for published version (APA):

de Koning, R. W. (1985). Human hepatocellular membrane antigens : studies on PLC/PRF/5 cells.

[Doctoral Thesis, Maastricht University]. Rijksuniversiteit Limburg. https://doi.org/10.26481/dis.19850315rk

Document status and date:

Published: 01/01/1985

DOI:

10.26481/dis.19850315rk

Document Version:

Publisher's PDF, also known as Version of record

\section{Please check the document version of this publication:}

- A submitted manuscript is the version of the article upon submission and before peer-review. There can be important differences between the submitted version and the official published version of record.

People interested in the research are advised to contact the author for the final version of the publication, or visit the DOI to the publisher's website.

- The final author version and the galley proof are versions of the publication after peer review.

- The final published version features the final layout of the paper including the volume, issue and page numbers.

Link to publication

\footnotetext{
General rights rights.

- You may freely distribute the URL identifying the publication in the public portal. please follow below link for the End User Agreement:

www.umlib.nl/taverne-license

Take down policy

If you believe that this document breaches copyright please contact us at:

repository@maastrichtuniversity.nl

providing details and we will investigate your claim.
}

Copyright and moral rights for the publications made accessible in the public portal are retained by the authors and/or other copyright owners and it is a condition of accessing publications that users recognise and abide by the legal requirements associated with these

- Users may download and print one copy of any publication from the public portal for the purpose of private study or research.

- You may not further distribute the material or use it for any profit-making activity or commercial gain

If the publication is distributed under the terms of Article $25 \mathrm{fa}$ of the Dutch Copyright Act, indicated by the "Taverne" license above, 
HUMAN HEPATOCELLULAR MEMBRANE ANTIGENS STUDIES ON PLC/PRF/5 CELLS 
Drukkerij Groenevelt b.v./Landgraaf 


\section{HUMAN HEPATOCELLULAR MEMBRANE ANTIGENS}

\section{STUDIES ON PLC/PRF/5 CELLS}

\section{PROEFSCHRIFT}

ter verkrijging van de graad van doctor in de geneeskunde aan de Rijksuniversiteit Limburg te Maastricht, op gezag van de Rector Magnificus, Prof.dr. F.L.M. Bonke, volgens het besluit van het College van Dekanen, in het openbaar te verdedigen op 15 maart 1985, om 16.00 uur

door

Rudolf W. de Koning

geboren te Zwijndrecht in 1950 
Promotores: Prof.dr. F.T. Bosman

Prof.dr. H.A.M. Hulsmans

Referenten : dr. G.H. Blijham

Prof.dr. H.J. Houthoff

Prof.H.C. Thomas, PhD, FRCP 
In memory of my sister Ina. 



\section{CONTENTS}

GENERAL INTRODUCTION

CHAPTER I: Hepatocellular carcinoma

1.1. Clinicopathologic aspects

1.1.1.

Epidemiology and etiology

1.1.2.

Symptomatology and diagnosis

1.1.3.

Therapy

1.1.4.

Pathology

1.2 .

Cytopathologic aspects

Hepatocellular carcinoma derived cell lines $\quad 17$

1.2 .1 .

Tumour associated antigens

1.2.2.

Design of the present study

1.3.

Membrane antigens of PLC/PRF/ 5 cells

1.3.2. Induction and characterization of antibodies against PLC/PRF/5 cells

1.4.

References

CHAPTER II: Autoantibodies in liver disease

2.1.

2.1.1.

2.1.2.

2.1.3.

2.2 .

2.2.1.

2.2.2.

2.2.3.

2.3.

2.4

CHAPTER III: Hepatitis B virus and host cell membrane antigens on a hepatocellular carcinoma cell line 
3.2.1. Cell cultures 42

3.2.2. Immunofluorescence 42

3.2.3. Capping 42

3.2.4. Co-capping 43

3.2.5. OKT9 antigen display 43

3.2.6. HLA Type I phenotyping 43

3.3. Results 43

3.4. Discussion 44

3.5. Summary 46

3.6. References 47

CHAPTER IV: Induction and characterization of antibodies against PLC/PRF/5 cells

4.1. Introduction 49

4.2. Materials and methods $\quad 50$

4.2.1. Cell types 50

4.2.2. Masking of human liver cell membrane antigens 52

4.2.3. Production of antiserum against PLC/PRF/5 cells 52

4.2.4. Production of hybridomas 53

4.2.5. Antibody assay procedures 54

4.2.6. Adsorbtion of antiserum 56

4.2.7. Blocking 56

4.3. Results 57

4.3.1. The conventional approach 57

4.3.2. The hybridoma approach 63

4.4. Discussion 65

4.5. $\quad$ References 68

CHAPTER V: Liver membrane antibodies: studies on PLC/PRF/5 cells

5.1. Immunofluorescence detection of liver cell

membrane antibodies using PLC/PRF/5 cells 71

5.1.1. Introduction 71

5.1.2. Materials and methods $\quad 72$

5.1.2.1. Sera 72

5.1.2.2. Cell lines $\quad 72$

5.1.2.3. Immunofluorescence test $\quad 72$

$\begin{array}{lll}5.1 .2 .4 . & \text { Flowcytometry } & 73\end{array}$

5.1.3. Results 73

$\begin{array}{lll}\text { 5.1.4. Discussion } & 75\end{array}$

5.1.5. Summary $\quad 78$ 
5.1.6. References

5.2 .

Human hepatoma cell reactive antibodies in inflammatory liver disease: a study on

PLC/PRF/5 cells

5.2.1.

Introduction

5.2 .2 .

Materials and methods

5.2.2.1.

Patient material

82

5.2.2.2.

PLC/PRF/5 cells

82

5.2.2.3.

Immunofluorescence test

83

5.2.2.4

Flowcytometry

83

5.2 .3 .

Results

84

5.2.4.

Discussion

86

5.2.5.

Summary

90

5.2 .6 .

References

CHAPTER VI: General discussion

6.1.

Liver membrane antigens: current status

93

6.2 .

Membrane antigens on PLC/PRF/ 5 cells

6.3 .

Induction of polyclonal and monoclonal

antibodies against PLC/PRF/5 cells

95

6.3 .1 .

Conventional approach

95

6.3.2.

Hybridoma approach

96

6.3 .3

Future prospects

97

6.4 .

Antibodies against hepatocellular membrane antigens

98

6.4.1.

Established antibodies and liver injury

98

6.4.2.

PLC/PRF/5 cells and liver membrane antibodies

6.5 .

Conclusions

100

6.6 .

References

101

SUMMARY

105

SAMENVATTING

ACKNOWLEDGEMENTS 



\section{GENERAL INTRODUCTION}

Cell membranes play an important role in the regulation and expression of cellular functions. Membrane receptors are the regulatory targets for humoral modulators of cell function. Exocytosis of cell products through the cell membrane is an important mechanism in the expression of cellular function. Membrane antigens are of paramount importance for adequate functioning of the humoral and cellular immune system. As a consequence, the cell membrane has been an important target in the study of normal and pathological conditions of numerous cell types.

In liver pathology the main emphasis regarding the cell membranes has been on antigens of hepatocytes and their possible role as target antigens for autoantibodies. More recently, the significance of cell membrane antigens in regard of diagnostic and therapeutic aspects of hepatocellular carcinoma has received some interest. Ideally, the characteristics of the cell membrane should be studied on isolated cells rather than on whole tissue fragments or in fractionated tissue homogenates, because interactions between different cell types, or contamination of hepatocellular membranes with those of other cell types in the liver, can hardly be avoided. Hepatocytes in tissue culture would be an ideal substrate for investigations concerning the cell membrane. Normal hepatocytes can, however, be cultured only briefly and are extremely difficult to keep in continuously growing cell lines. We therefore tested the possible use of a well-differentiated human hepatocellular carcinoma cell line (the PLC/PRF/5 - also known as Alexander cell line) for studies of inflammatory and neoplastic liver diseases. These studies are the topic of this thesis.

We characterized initially some of the membrane antigens of PLC/PRF/5 cells. Based on these findings we developed a test, using PLC/PRF/5 cells as a substrate, for the detection of circulating antibodies against antigens on hepatocytes; this test was subsequently applied to a large number of sera from patients with different types of inflammatory hepatocellular diseases.

A parallel series of investigations concerned attempts to develop specific antibodies directed against tumour specific or tumour associated antigens on hepatocellular carcinoma cells, which might be useful for diagnostic and/or therapeutic purposes. 



\section{CHAPTER I}

\section{Hepatocellular carcinoma}

\subsection{CLINICOPATHOLOGIC ASPECTS}

\subsubsection{Epidemiology and etiology}

Remarkable differences in the geographical distribution of hepatocellular carcinoma $(\mathrm{HCC})$ have been recorded. While the incidence rates for most Western countries are below 2 per 100.000 a year, Tock (1980) found rates of up to 29 per 100.000 in Singapore. In China $\mathrm{HCC}$ is the most common tumour in the age group of 15-44 years old and accounts for about $14 \%$ of all cancer deaths (Terry, 1978).

The tumour is most prevalent in Southern Africa, especially in Mozambique. Mozambican Shangaan males have the highest incidence rate in the world, namely 103,8 per 100.000 per annum (Linsell, 1976).

Several factors play a role in the etiology of HCC. Important factors in human $\mathrm{HCC}$ are aflatoxin, alcohol and cirrhosis. Some chemical agents have been shown to be hepatocarcinogenic in animals (Wogan, 1976; Okuda, 1982).

The single most important factor associated with $\mathrm{HCC}$ in man, however, appears to be hepatitis B virus (HBV). How HBV functions in the etiology of HCC has not been elucidated as yet (Gerin, 1983).

The following observations support the association between $\mathrm{HBV}$ and HCC:

1. A geographical correlation exists between $\mathrm{HBsAg}$ carrier prevalence and $\mathrm{HCC}$ incidence (Kew, 1978a; Hadziyannis, 1980; Maupas, 1981).

2. Numerous case control studies showed a much higher prevalence of serum markers of HBV in patients with HCC than in controls (Szmuness, 1978).

3. A large prospective cohort study of male government employees in Taiwan showed a relative risk of 223 for the development of $\mathrm{HCC}$ in $\mathrm{HBsAg}$ carriers over $\mathrm{HBsAg}$ negative controls (Beasley, 1981).

4. Family studies of patients with HCC showed an excess of maternal HBsAg carriers (Sung, 1980).

5. In some cell lines derived from human HCC HBsAg production has been established (Macnab, 1976a).

6. Integration of HB-viral sequences into cellular DNA has been demonstrated in HCC cell lines (Marion, 1980; Chakraborty 1980; Edman, 1980) and directly in biopsy specimens of HCC (Shafritz, 1981).

7. In two species (woodchuck and Peking duck) an association between HBV-like viruses and HCC was found (Summers, 1981; Popper, 1981).

Direct evidence for an etiological role of HBV in the genesis of HCC in man is difficult to provide and the lack of a suitable animal model has hampered an experimental 
approach to this problem. However, if HBV infection could be prevented in areas with a high prevalence of both HBV and HCC (e.g. by HB-vaccination), a subsequent significant decrease of $\mathrm{HCC}$ would provide important additional evidence. Currently, such a prevention program using a hepatitis B vaccin has been initiated in Senegal (Maupas, 1981).

\subsubsection{Symptomatology and diagnosis}

The symptoms of HCC are unspecific and not diagnostic. Remarkable differences in symptoms appear to exist between high and low incidence areas. In high incidence areas $\mathrm{HCC}$ is not infrequently encountered in the second decade of life and male preponderance is high (8:1) (Kew, 1981). Right-sided upper abdominal pain and hepatomegaly are usually the presenting symptoms. Cirrhosis, which frequently precedes $\mathrm{HCC}_{\text {, }}$ is often clinically silent (Murray-Lyon, 1983).

In low incidence areas the tumour occurs from the sixth decade of life with a less prominent male predominance $(2,5: 1)$ (Ihde 1974). A more insidious course with gradual deterioration of the general condition is seen in patients with a previously established cirrhosis. These patients frequently (50-70\%) complain of upper abdominal pain (Linder, 1974). Occasionally, a characteristic friction rub and/or arterial murmur may be heard (Clain, 1966). For a final diagnosis of HCC a liver biopsy -preferably under ultrasonographic or laparoscopic control- is essential.

In most cases the standard liver tests are abnormal in a non-specific pattern but frequently with a markedly elevated alkaline phosphatase. Total ferritin levels are often raised (Kew, 1978b). Perhaps more specific for HCC are the acidic ferritins (Bullock, 1980). Occasionally an increased serum unsaturated vitamin $B_{12}$ binding capacity has been reported in HCC, mainly in the fibrolamellar variant (Paradinas, 1982). In a recent study (Shinagawa, 1984) real time ultrasonography (92\%) compared favourably with computed tomography $(73 \%)$, scintigraphy $(50 \%)$ and angiography $(86 \%)$ in the detection of small HCC nodules in mostly cirrhotic patients. However, in these patients frequently false-positive observations were encountered with ultrasonography.

Soon after the detection of hepatitis B surface antigen ( $\mathrm{HBsAg}$ ) a relatively high prevalence in HCC patients was recognized (Sherlock, 1970; Macnab, 1976b). A lower prevalence of anti-HBs was found in HCC compared with controls (Okuda, 1980). In a South African study (Kew, 1981) markers of hepatitis B virus (HBV) were found in $96 \%$ of $\mathrm{HCC}$ cases as compared to $74 \%$ in controls. The most discriminating marker in this study appeared to be IgM-anti HBcore: $35 \%$ in HCC and $4 \%$ in controls. Many attempts have been made to use serum levels of tumour associated antigens for screening or diagnostic purposes. Raised levels of carcino-embryonic antigen (CEA) have been reported in patients with $\mathrm{HCC}$ (Gerfo, 1971). Although the range of conditions with raised CEA limits its diagnostic usefulness, it may occasionally be of value in following the effects of treatment (Murray-Lyon, 1983). 
Alpha-foetoprotein (AFP) (Abelev, 1971) is of more diagnostic value than CEA or other serological parameters (Amery, 1977). In patients with a small HCC, serum AFP often remains mildly abnormal for some time and then suddenly may rise steeply (Obata, 1975). On the other hand high levels of AFP can be found in patients with chronic liver disease without any indication for the presence of $\mathrm{HCC}$. In these cases AFP concentrations frequently fluctuate and may even return to normal (Thomas, 1979). Nevertheless, in high incidence areas AFP may be a helpful screening parameter. In a Chinese study over a thousand cases of $\mathrm{HCC}$ were detected through screening of an unselected population of five million people for elevated AFP levels (Zhaoyou, 1980). However, AFP levels can also be normal in HCC. In a prospective Japanese study of cirrhosis or chronic hepatitis patients, 7 out of 31 cases of HCC had normal AFP levels (Kubo, 1978). These studies indicate that AFP cannot be considered as a conclusive diagnostic test. More specific diagnostic tools are necessary for screening purposes in high risk groups and for final confirmation of the diagnosis. In this respect $\mathrm{HCC}$ specific antigen(s) as target(s) for immunological diagnostic tests would be extremely valuable.

\subsubsection{Therapy}

The results sofar of chemotherapy and radiotherapy of primary hepatocellular carcinoma have been disappointing (Falkson, 1976; Johnson, 1978; Olweny, 1980; Moertel, 1981). Advances in early detection and surgical technique have improved the survival rates of patients with limited and favourably located solitary $\mathrm{HCC}$ (Foster, 1977; Fortner, 1978; Okuda, 1984). Early detection of HCC, with a consequent reduction in the rate of metastasis, might improve the results of surgery in general and of orthotopic liver transplantation in particular. Along this line impressive results of partial hepatic resection have been recently reported from China where, through mass survey of over five million people more than thousand cases of HCC were detected using an AFP immunoassay (Zhaoyou, 1980). When these patients were compared with symptomatic cases, three-year survival after resection was twice that of the symptomatic group ( $62 \%$ versus $26 \%$ ). From these data it is clear that early diagnosis is of paramount importance in the improvement of the prognosis of $\mathrm{PHC}$.

New perspectives for surgical treatment are offered by total hepatectomy and orthotopic liver transplantation. However, in the two centres with major experience with hepatic transplantation for the treatment of $\mathrm{HCC}$, the evidence supporting the value of orthotopic liver transplantation is not convincing (Starzl, 1979; Calne, 1979). The high operative morbidity and mortality and the significant risks associated with longterm immunosuppression, which may favour tumour recurrence and metastases, are important limiting factors in this approach. Therefore further advances in the management of HCC may be provided by the establishment of specific serological markers for HCC which would make early detection possible. In addition, identification of HCC specific antigens would potentially allow radioimmunotargeting of metastases, and even immunotargeting of chemotherapeutic agents. 


\subsubsection{Pathology}

The macroscopic appearances of HCC largely depend on the presence or absence of pre-existing cirrhosis (Lee, 1966; Mori, 1980). Carcinoma arising in a non-cirrhotic liver usually grows as a fairly homogeneous mass, in later stages with satellite nodules. In contrast $\mathrm{HCC}$ arising in cirrhotic or precirrhotic livers tends to be multinodular, mimicking cirrhotic nodules (Edmondson, 1982).

Three forms are usually distinguished (Gall, 1969):

- nodular, with muitiple nodules scattered throughout the liver;

- massive, with one dominant large mass with a variable degree of intrahepatic spread;

- diffuse, a rarely occurring pattern with extensive fine nonnodular infiltration of the liver.

Regional variations have been reported. The liver tumours tend to be larger in Africarns than in Caucasians (Alpert, 1969). Small tumours, measuring less than $4 \mathrm{~cm}$, are much more frequently encountered in the Japanese (Kondo, 1983). Classification on microscopical appearances is generally based on the following parameters: general architecture, cytological characteristics and the concurrent proliferation of connective tissue stroma (Altmann, 1978). The trabecular form, undoubtedly the most common manifestation, shows hepatocyte like intermediary sized tumour cells arranged in multilayered trabeculae with wide intervening vascular spaces which are lined by endothelial cells but lack Kupffer cells. Reticulin fibres are scarce or absent.

The compact form consists of multilayered cell clusters with inconspicuous or absent sinusoids. The pseudoglandular or acinar variety shows tumour cells arranged in a pattern resembling dilated bile canaliculi or surrounding pseudolumina created by necrosis of central cells (Gibson, 1978). An unusual HCC variant, which usually occurs in non-cirrhotic liver, is characterized by clusters of deeply eosinophilic hepatocytes separated by parallel bundles of collagen. This so called fibrolamellar variant, which is common in younger patients (Farhi, 1983), is more frequently resectable and has a better overall survival (Lack, 1983). Clear cell tumors are rare and closely resemble renal carcinoma. These tumours show a better prognosis (Berman, 1980). Histochemically HCC cells show pronounced activity of gamma glutamyl transpeptidase and generally reduced or no activity of adenosine triphosphatase and giucose -6- phosphatase (Gerber, 1980). Very rarely can HBsAg be demonstrated within tumour cells by immunocytochemistry (Nayak, 1977; Thung, 1979). Intracellular HBsAg is common in the non-tumorous part of liver of HBsAg positive patients especially with trabecular HCC (Uchida, 1978). Other immunocytochemically detectable antigens are AFP, CEA and alpha-1-antitrypsin (Okita, 1977; Thung, 1979). 


\subsection{CYTOPATHOLOGIC ASPECTS}

\subsubsection{Hepatocellular carcinoma derived cell lines}

In recent years, several human $\mathrm{HCC}$ cell lines have been established and their biological characteristics have been examined rather extensively. They show more or less octogonally shaped cells in culture. Generally these cells contain different amounts of liwer enzymes and some produce coagulation factors and/or albumin. (Chen, 1980; Knowles, 1980; Das, 1980; He, 1982; Matsumura, 1983; Chang, 1983; Levin, 1983). Our discussion of HCC derived cell lines will be largely confined to the PLC/PRF/5 line which has been studied most extensively (Alexander, 1976; Marion, 1979; Aden, 1979; Skelly, 1979). In the supernatant of this cell line HBsAg subtype ad was found by radioimmunoassay (Macnab, 1976a). By electron microscopy only spherical HBsAg particles were detected, while no $\mathrm{HBcAg}$ nor Dane particles could be identified (Stannard, 1977). Studies of infectivity in chimpanzees with whole PLC/PRF/5 cells or tissue culture fluid did not reveal any evidence for the production of infectious HB virus (Daemer, 1980; Tabor, 1981). Subsequently the DNA hybridization technique became available and the presence of integrated hepatitis $B$ virus DNA sequences in cellular DNA of the PLC/PRF/5 cell line was demonstrated (Chakraborty, 1980; Brechot, 1980; Edman, 1980; Twist, 1981). Further a defective hepatitis B virus DNA molecule was detected in a stable integration pattern (Monjardino, 1983).

The production of many serum proteins by the PLC/PRF/5 cells has been reported: alpha-1-antitrypsin, transferrin, alpha-2-macroglobulin, alpha-fetoprotein and complement components, but not albumin (Dodd, 1978; Gerber, 1981; Tabor, 1981; Allexander 1982). A CEA-like antigen is also produced by these cells (Gerber, 1981). Subsequently liver specific lipoprotein has been demonstrated on the PLC/PRF/5 cell membrane (Lebwohl, 1981; Sakaguchi, 1983). Recently depression of natural killer (NK) cell activity and activation of T-suppressor cells by supernatant of PLC/PRF/5 cells were reported (Keong, 1983a; Keong, 1983b).

PLC/PRF/5 cells have been grown in athymic mice (Desmyter, 1981; Shouval, 1981 ; Bassendine, 1982). In this model a positive correlation between serum AFP concentration and tumour mass has been found (Bassendine, 1983). Shouval (1982a) demonstrated selective binding and complement mediated lysis of PLC/PRF/5 cells in culture by monoclonal antibodies to hepatitis $\mathrm{B}$ surface antigen. He subsequently reported that $\operatorname{IgM}$ and $\mathrm{IgG} 2 \mathrm{a}$ monoclonal anti-HBs antibodies specifically prevent or suppress tumour formation in a substantial number of athymic nude mice injected with PLC/PRF/5 cells (Shouval, 1982b). Recently Oladapo (1984) found more pronounced inhibition of PLC/PRF/ 5 tumour growth in nude mice after administration of ricin conjugated monoclonal anti-HBs than after native monoclonal anti-HBs. The described athymic mouse model appears to be of potential importance for the testing of native or toxin conjugated monoclonal antibodies against hepatoma-specific antigenic determinants. 


\subsubsection{Tumour associated antigens}

In the development of new approaches to diagnosis and treatment of cancer, including HCC, tumour associated antigens (TAA) play a crucial role. In this paragraph we therefore shall first discuss some general aspects of TAA and subsequently focus on $\mathrm{HCC}$ associated antigens.

\subsubsection{History}

Since the final decades of the last century the possible role of the immune response as a host defense mechanism against the development and growth of malignant tumours has been the subject of extensive speculation and experimentation.

The presence of specific antigens on tumours was supported by transplantation experiments of carcinogen induced tumours in syngeneic animals. Although this early work suggested that tumour cells carry antigens capable of eliciting specific immunological responses in the host, unequivocal arguments in favour of the occurrence of tumour specific antigens were not provided. Reliable characterization of the antigens on tumour cells has appeared to be a cumbersome and laborious task which as yet has not yielded antigens specific for cancer cells.

The expression of antigens on normal cells undergoes membrane modification during cell differentiation and maturation. New antigens are acquired when cells acquire more specialized functions. In the process of evolution organ-specific antigens have been modified by mutation, giving rise to polymorphism. These organ-specific antigens are genetically unrelated to the generally occurring antigens, e.g. human leucocyte antigens (HLA), which have wide tissue distribution.

In recent years the complexity of cell surface antigens, coded by major histocompatibility complex (MHC) linked genes and non-MHC linked genes has been increasingly recognized. Some determinants expressed on tumour cells and formerly considered to represent tumour-associated antigens must now after re-evaluation be regarded as an expression of genetically appropriate and tissue-restricted allo-antigens (Pollack, 1980; Imamura, 1980; McAlack, 1980). Neoplastic transformation is also known to be associated with quantitative changes in the expression of normal cellular antigens. The effect can be either an increase or a decrease of these normal antigens (Peacocke, 1966; Ting, 1976).

So far intensive research on the expression of TAA has yielded disappointingly few positive results. One example is the work of Blank (1977) who reported evidence for an $\mathrm{H}-2$ /viral protein complex on the surface of a Friend virus-induced murine tumourcell.

\subsubsection{Tumour associated antigens in human tumours}

Various TAA have been found in human tumours including virus-associated and 
oncodevelopmental antigens. Epstein-Barr viral antigens have been identified in cells from Burkitt's lymphoma and nasopharyngeal carcinoma (Zeng, 1983), while hepatitis $B$ virus antigen has been detected in hepatocellular carcinoma cells (Okuda, 1979). Hepatitis B viral antigens, however, also occur in infected non-neoplastic cells (Hadziyannis, 1972; Huang, 1975). In some tumours antigens are expressed, which are shared with embryonic, but not with normal adult cells - the so called oncodevelopmental antigens. The two best characterized oncodevelopmental antigens associated with human tumours are carcinoembryonic antigens (CEA) and alpha-fetoprotein (AFP). These antigens have little immunogenic potential and in addition also occur in non-neoplastic cells and therefore are not ideal for diagnostic or therapeutic use. The advent of the hybridoma technology (Köhler and Milstein, 1975) resulting in the development of monoclonal antibodies has created great expectations, also in terms of potential for the identification of TAA. However, so far no truely tumour-specific TAA have been identified, because invariably an extensive enough search has revealed crossreactivities with non-neoplastic tissues (Dippold, 1980; Pallesen 1983; Arends, 1983).

\subsubsection{Tumour associated antigens in hepatocellular carcinoma}

The identification of alpha-fetoprotein in human fetal serum (Bergstrand, 1957), and the discovery (Abelev, 1963) of this protein in the serum of mice with chemicallyinduced hepatocellular carcinoma and of humans with HCC (Tatarinov, 1964) raised the exciting prospect that a tumour associated marker for this highly malignant tumour might exist. AFP is not always found in HCC. Even sensitive radioimmunoassays do not detect AFP in every case of HCC, e.g. raised AFP levels are encountered in 70-90\% of HCC patients in low incidence regions (Kew, 1982a). At the tissue level AFP has been visualized by immunoenzymatic techniques in only a small proportion of the tumour cells in HCC (Peyrol, 1978; Kojiro, 1981). Subsequently, AFP appeared not to be HCC specific because is was detected in sera of patients with other liver diseases: acute viral and toxic hepatitis, chronic active hepatitis and cirrhosis (Kew, 1974; Ruoslahti, 1979) and also in other tumour types such as undifferentiated teratocarcinomas of the testis and ovary (Finkelstein, 1970; Smith, 1971) and occasionally in tumours of endodermal differentiation (Kew, 1974; Ruoslahti, 1979). Although AFP is moderately useful for diagnostic purposes, it is most helpful to therapyassessment (Matsumoto, 1976; McIntire, 1976); sometimes, however, serum AFP levels may decrease in spite of tumour recurrence (Esterhay, 1973).

In view of the absence of AFP in a considerable proportion of HCC patients, especially in low incidence regions, and the lack of hepatoma specificity, the search for HCC specific antigens has continued.

Baldwin (1976) demonstrated a multiplicity of tumour specific TAA in chemicallyinduced hepatic tumours in rats, although in many spontaneous tumours arising in vivo no specific TAA were found. Moreover, it has appeared to be impossible to in- 
duce an immune response against spontaneous human or animal tumours in contrast to virally or chemically induced tumours (Hewitt, 1976; Kew, 1982b).

On the other hand, two preliminary communications point to the possibility that relatively specific monoclonal antibodies to HCC cell membrane antigens may be obtained (He, 1982; Wiedmann, 1983). In these studies crossreactivity of the antibodies with viral or embryonic antigens was not excluded.

Concurrently, the search for HCC specific antigens has been largely unsuccessful sofar. The generation of HCC specific monocional antibodies would give the opportunity for interesting new diagnostic and therapeutic developments. Radiolabelled specific monoclonal antibodies would allow scintigraphic localization of primary tumour and metastases (Moldofsky 1984), whereas conjugation of monoclonal antibodies with cytotoxic agents would allow specific immunotargeting of such drugs (Preliminary communication, Lancet, 1984).

\subsection{DESIGN OF THE PRESENT STUDY}

We have explored the potential application of $\mathrm{HCC}$ cells for the study of neoplastic hepatocellular diseases. To this end membrane associated antigens of PLC/PRF/5 cells were studied. Attempts were subsequently made to induce HCC specific antibodies using PLC/PRF/5 cells.

\subsubsection{Membrane antigens of PLC/PRF/5 cells}

In order to establish the potential usefulness of PLC/PRF/5 cells for the detection of TAA it is essential to be informed about the expression of several wellknown antigens on the cell surface. We therefore investigated the expression of HLA antigenic determinants, the presence of viral antigens, and of a division antigen (which is the transferrin receptor (Greaves, 1982)) on the plasma membrane of PLC/PRF/5 cells. The possibility of a physical association between HLA and viral antigens was also studied in view of the potential pathophysiological implications.

\subsubsection{Induction and characterization of antibodies against PLC/PRF/5 cells}

The feasibility of several possible approaches for the production of conventional polyclonal tumour specific antibodies was tested. An important element was the masking of normal hepatocyte antigens during the immunization procedures. Contamination of the obtained antiserum with antibodies against normal liver antigens was approached by absorption methods. Tumour specificity was tested on a panel of normal and tumour tissues. As these attempts appeared rather unsuccessful we also generated monoclonal antibodies against PLC/PRF/5 cells. Initially an optimal immunization procedure had to be established before hybridomas could be established. A reliable radiolabelled antiglobulin assay had to be developed for efficient initial 
screening. For the further characterization of productive hybridomas the antibodies were tested on a panel of normal hepatocytes of different species and on a variety of neoplastic or transformed, non-hepatocytic cell lines. 


\subsection{REFERENCES}

1. Abelev, G.I., Perova, S.D., Kramkova, N.I., Postnikova, Z.A., Irtin, I.S.

Production of embryonal alphaglobulin by transplantable mouse hepatomas.

Transplantation; 1: 174-180, 1963.

2. Abelev, G.I.

Alpha-fetoprotein in ontogenesis and its association with malignant tumors.

Adv. Cancer Res.; 14: 295-358, 1971.

3. Adlen, D.P., Fogel, A., Plotkin, S., Damjanov, I., Knowles, B.B.

Controlled synthesis of $\mathrm{HBs} \mathrm{Ag}$ in a differentiated human liver carcinoma derived cell line.

Nature; 282: 615-616, 1979.

4. Alexander, J.J,, Bey, E.M., Geddes, E.W., Lecatsas, G.

Establishment of a continuously growing cell line from primary carcinoma of the liver.

S.Afr.Med.J.; 50: 2124-2128, 1976.

5. Alexander, J.J., Merwe, Ch.F. van der, Saunders, R.M., McElligott, S.E., Desmyter, J.

A comparison between in vitro experiments with a hepatoma cell line and in vivo studies.

Hepatology; 2: 92s-96s, 1982.

6. Alpert, M.E., Hutt, M.S.R., Davidson, C.S.

Primary hepatoma in Uganda. A prospective clinical and epidemiologic study of 46 patients.

Amer.J.Med.; 46: 794-802, 1969.

7. Altmann, H.W.

Pathology of human liver tumors. In: Primary Liver Tumors : 53-73. Eds..: Remmer, H., Bolt, H.M., Bannasch, P., Popper, H.

MTP press; 1978.

8. Amery, A.H., Alston, W.C., Kohn, J., White, W.F.

Excessive alpha-fetoprotein concentrations in hepatocellular carcinoma.

Brit.Med.J.; 2: 611-612, 1977 .

9. Arends, J.W., Verstijnen, C., Bosman, F.T., Hilgers, J., Steplewski, Z.

Distribution of monoclonal antibody-defined monosialoganglioside in normal and cancerous human tissues: an immunoperoxidase study.

Hybridoma; 2: 219-229, 1983.

10. Baldwin, R.W., Price, M.R.

Immunology of experimental liver cell cancer.

In: Liver Cell Cancer : 203-243.

Eds.: Cameron, H.M., Linsell, D.A., Warwick, G.P.

Elsevier Scientific Publishing Company, 1976.

11. Bassendine, M.F., Oladapo J.M., Koning, R.W. de, Parmar, J., Thomas, H.C., Sherlock, S. Interferon therapy in hepatocellular carcinoma: studies in an animal model.

Hepatology; 2; 164; 1982.

12. Bassendine, M.F., Wright, N.A., Thomas, H.C., Sherlock, S.

Growth characteristics of alpha-fetoprotein secreting human hepatocellular carcinoma in athymic (nude) mice.

Clin.Sci.; 64: 643-648, 1983 .

13. Beasley, R.P., Hwang, L.Y., Lin, C.C., Chien, C.S.

Hepatocellular carcinoma and hepatitis $B$ virus.

Lancet; 11: 1129-1132, 1981 .

14. Bergstrand, C.G., Czar, B.

Paper electrophoretic study of human fetal serum proteins with demonstration of a new protein fraction.

Scand.J.Clin.Lab.Invest.; 9: 277-286, 1957.

15. Bergman, M.M., Libbey, N.P., Foster , J.H.

Hepatocellular carcinoma polygonal cell type with fibrows stroma - an atypical variant with a favourable prognosis.

"Cancer; 46: 1448-1455, 1980.

16. Blank, K.J. 
Evidence for an $\mathrm{H} 2 /$ viral protein complex on the cell surface as the basis for the $\mathrm{H} 2$ restriction of cytotoxicity.

Nature; 269: 808-809, 1977.

17. Brechot, C., Pourcel, C., Louise, A., Rain, B., Tiollais, P.

Presence of integrated hepatitis B virus DNA sequences in cellular DNA of buman hepatocellular carcinoma.

Nature; 286: 533-535, 1980.

18. Bullock, S., Bomford, A., Williams, R.

A biochemical comparison of normal human liver and hepatocellular carcinoma ferritins.

Biochem.J.; 185: 639-645, 1980.

19. Calne, R.Y., Williams, R.

Liver transplantation.

Curr.Probl.Surg.; 16: 3-44, 1979.

20. Chakraborty, P.R., Luiz Opazo, N., Shouval, D., Shafritz, D.A.

Identification of integrated hepatitis B virus DNA and expression of viral RNA in an HBsAg producing human hepatocelluiar carcinoma cell line.

Nature; 286; 531-533, 1980.

21. Chang, C., Lin, Y., O-Lee, T.W., Chou, C.K., Lee, T.S., Liu, T.I., P'Eng, F.K., Chen, T.Y., $\mathrm{Hu}, \mathrm{C.P}$.

Induction of plasma protein secretion in a newly established human hepatoma cell line. Mol.Cell Biol.; 3: 1133-1137, 1983.

22. Chen, R., Zhu, D., Ye, X., Shen, D., Lu, R.

Establishment of three human liver carcinoma cell lines and some of their biological characteristics in vitro.

Sci.Sin.; 23: 236-247, 1980.

23. Clain, D., Wartnaby, K., Sherlock, S.

Abdominal arterial murmurs in liver disease.

Lancet; 11: $516-519,1966$.

24. Daemer, R.J., Feinstone, S.M., Alexander, J.J., Tully, J.G., Londlon, W.T., Wong, D.C., Purcell, R.H.

PLC/PRF/5 (Alexander) hepatoma cell line: further characterization and studies of infectivity. Infect.Immunol.; 30: 607-611, 1980.

25. Das, P.K., Nayak, N.C., Tsiquaye, K.N., Zuckerman, A.J.

Establishment of a human hepatocellular carcinoma cell line releasing hepatitis $B$ virus surface antigen.

Brit.J.Exp.Pathol; 61: 648.654, 1980.

26. Desmyter, J., de Groote, II., Ray, M.B., Bradburne, A.F., Desmet, V., De Somer, P.» Alexander, J.J.

Tumorigenicity and interferon properties of the PLC/PRF/S human hepatoma cell line.

Prog.Med.Virol; 27: 103-108, 1981.

27. Dippold, W.G., Lloyd, K.O., Li, L.T., Ikeda, H., Oettgen, H.F., Old, L.J.

Cell surface antigens of human malignant melanoma: definition of six antigenic systems with mouse monoclonal antibodies.

Proc.Natl.Acad.Sci.USA; 77: 6J14-6118, 1980.

28. Dodd, R., Gouaux, T., Bastiaans, M.

Biosynthesis of HBisAg and serum proteins by a human hepatoma cell tine.

In: Viral Hepatitis, 698-709.

Eds.: Vyas, G., Cohen, S., Schmidt, $R$.

Franklin Institute Press, Philadelphia, 1978.

29. Edman, J.C., Gray, P., Valenzuela, P., Rall, L.B., Rutter, W.J.

Integration of hepatitis $B$ virus sequences and their expression in a human hepatoma cell.

Nature; 286: 535-538, 1980.

30. Edmondson, H.A., Peters, R.L.

Neoplasms of the liver.

In: Diseases of the Liver: 5: 1101-1157. 
Eds:: Schiff, L., Schiff, E., Lippincott Company, 1982.

31. Esterhay, R.J., Shapiro, H.M., Sutherland, J.C., Mclntire, K.R., Wiernik, P.H.

Serum alpha-fetoprotein concentration and tumor growth dissociation in a patient with ovarian teratocarcinoma.

Cancer; 31: 835-839, 1973 .

32. Falkson, G. Moertel, C.G., Lawin, P.T.

Chemotherapy of primary liver carcinoma: a parallel study in American and African Bantu patients.

Proc.Amer.Assoc.Cancer Res.; 17: 21-26, 1976.

33. Farhi, D.C., Shikes, R.H., Murrari, P.J., Silverberg, S.G.

Hepatocellular carcinoma in young people.

Cancer; 52: 1516-1525, 1983.

34. Finkellstein, J.Z.Higgins, G.R., Faust, J., Karon, M.

Serum alpha-fetoprotein and malignancy in children.

Cancer; 30: 80-86, 1970.

35. Fortner, J.G., Kim, D.K., Maclean, B.J., Barret, M.K., Iwatsuki, S., Turnbull, A.D., Howland, W.S., Beattie, E.J.

Major hepatic resection for neoplasia: personal experience in 108 patients.

Ann.Surg, ; 188: 363-371, 1978.

36. Foster, J.H., Berman, M.M.

Solid Liver Tumours.

Major Problems in Clinic Surgery; vol.22, Saunders, Philadelphia, 1977.

37. Gall, E.A.

Tumors of the liver.

Ed.: Schiff, L., Lippincott, Philadelphia, 1969.

38. Gerber, M.A., Thung, S.N.

Enzyme patterns in human hepatocellular carcinoma.

Amer.J.Pathol.; 98: 395-400, 1980.

39. Gerber, M.A., Garfinkel, E., Hirschman, S.Z., Thung, S.N., Panagiotatos, T.

Immune and enzyme histological studies of a human hepatocellular carcinoma cell line producing hepatitis B surface antigen.

J.Immunol.; 126: 1085-1089, 1981.

40. Gerfo, P.L., Krupey, J., Hansen, H.J.

Demonstration of an antigen common to several varieties of neoplasia.

N.Engl.J.Med ; 285: 138-141, 1971,

41. Gerin, J.L.

Hepatitis $B$ virus and primary hepatocellular carcinoma.

Gastroenterology" 84: $869.876,1983$.

42. Gibson, J.B., Sobin, L.H.

Histological typing of tumors of the liver, biliary tract and pancreas.

In: International Histological Classification of Tumors, no. 20.

World Health Organisation, 1978.

43. Greaves, M.F.

Target-cells, cellular phenotypes and lineage fictelity in human leukaemia.

J.Cell.Phys.; SI: 113-125, 1982.

44. Hadziyannis, S., Vissoulis, C. Moussouros, A., Afroudakis, A.

Cytoplasmic localisation of Australia antigen in the liver.

Lancet; I: 976-979, 1972.

45. Haziyannis, S.Y.

Hepatocellular carcinoma and type B hepatitis.

Clin.Gastroenterol.; 9: 117-134, 1980.

46. He, L., Isselbacher, K.J., Wands, J.R.

Monoclonal antibodies to a new human hepatocellular carcinoma cell line - CUSPF (Abstract).

Hepatology: 2: 677, 1982.

47. Hewitt, H.B., Blake, E.R., Walder, A.S. 
A critique of the ewidence for active host defence against cancer based on personal studies of 27 murine tumours of spontaneous origin.

Brit.J.Cancer; 33: 241-259, 1976.

48. Huang, S.N.

Immunohistochemical demonstration of hepatitis B core and surface antigens in paraffin sections.

Lab.Invest.; 33: 88-95, 1975.

49. Ihde, D.C., Sherlock, S., Wünawer, S.J.

Clinical manifestations of hepatoma.

Aner.J.Med.; 56: 83-91, 1974.

50. Imamura, M., Martin, W.J.

Variation in expression of $\mathrm{H} 2$-histocompatibility antigens on tumor cells.

Transplant.Proc.; 12: 77-80, 1980.

51. Johnson, P.J., Williams, R., Thomas, H.C., Sherlock, S., Murray-Lyon, 1.M.

Induction of remission in hepatocellular carcinoma with doxorubicin.

Lancet; 1: 1006-1009, 1978.

52. Keong, A., Herman, J, Rabson, A.R.

Supernatant derived from a human hepatocellular carcinoma cell line (PLC/PRF/5) depresses natural killer (NK) cell activity.

Cancer Immunol.Immunother.; 15: 183-187, 1983a.

53. Keong, A., Rabson, A.R.

Supernatant derived from a human hepatocellular carcinoma cell ine (PLC/PRF/5) activates a population of T-suppressor cells.

Cancer Immunol.Immunother.; 15: 178-182, $1983 \mathrm{~b}$.

54. Kew, M.C.

Alpha-fetoprotein in primary liver cancer and other diseases.

Gut; 15: 814-819, 1974.

55. Kew, M.C.

Hepatoma and the HBV.

In: Viral Hepatitis. Etiology, Epidemiology, Pathogenesis and Prevention.

Eds,: Vyas, G.N., Cohen, S.N., Schmidt, R.

The Franklin Institute Press, Philadelphia, 1978a.

56. Kew, M.C., Torrande, J.D., Derman, D., Simon, M., Macnab, G.M., Charlton, R.W., Bothwell, $\mathbf{H}$.

Serum and tumour ferritins in primary liver cancer.

Gut; 19: 294-299, 1978 b.

57. Kew, M.C.

Clinical, pathological and etiological heterogeneity in hepatocellular carcinoma: evidence from Southern Africa.

Hepatology; 1: 366-369, 1981.

58. Kew, M.C.

Tumour markers in hepatocellular carcinoma.

In: Hepatocellular carcinoma: $130-135$.

UICC Technical Report Series; 74: 1982a.

59. Kew, M.C., Mackay, I.R., Thomas, H.C.

Host-tumour interactions.

In: Hepatocellular carcinoma: 136-155.

Eds.: Okuda, $\mathbf{K}_{\text {., Mackay, I.R. }}$

60. Knowles, B. B., Howe, C.C., Aden, D.P.

Human hepatocellular carciroma cell lines secrete the major plasma proteins and hepatitis $\mathbf{B}$ surface antigen.

Science; 209: 497-499, 1980 .

61. Köhler, G., Milstein, C.

Continuous culture of fixed cells secreting antibodies of predefined specificity.

Nature; 256: 495-497, 1975.

62. Kojiro, M., Kawano, Y., Issomura, T., Nakashima, T. 
Distribution of albumin-and/or alpha-fetoprotein-positive cells in hepatocellular carcinoma. Lab.Invest,; 44: 221-226, 1981.

63. Kondo, IY., Niwa, Y., Akikusa, B., Takazawa, H., Okabayashi, A.

A histopathologic study of early hepatocellular carcinoma.

Cancer; 52: 687-692, 1983.

64. Kubo, Y., Okuda, K., Musha, H., Nakashima, T.

Detection of hepatocellular carcinoma during a clinical follow-up of chronic liver disease: observations in 31 patients.

Castroenterology: 74: $578-582,1978$.

65. Lack, E.E., Neave, C., Vawter, G.F.

Hepatocellular carcinoma.

Cancer; $52: 8: 1510-1515,1983$.

66. Lebwohl, N., Gerber, M.A.

Characterization and demonstration of human tiver-specific protein (LSP) and apo-LSP.

Clin.Exp.Immunol; 46: 435-442, 1981 .

67. Lee, F.I.

Cirrhosis and hepatoma in alcoholics.

Gut; 7: 77-85, 1966 .

68. Levin, E.G., Fair, D.S., Loskutoff, D.J.

Human hepatoma cell line plasminogen activator.

J.Lab.Clin.Med ; 1.02: 500-508, 1983.

69. Linder, G.T., Crook, J.N., Cohn, I.

Primary liver carcinoma.

Cancer; 33: 1624-1629, 1974.

70. Linsell, C.A., Higginson, J.

The geographic pathology of liver cell cancer.

In: Liver Cell Cancer; $\mathbb{1}-16$.

Eds.: Cameron, H.M., Linsell, C.A., Warwick, G.P.

Elsevier, Amsterdam, 1976.

71. McAlack, R.F.

Normal HLA phenotypes and neo-HLA-like antigens on cultured human neuroblastoma.

Transplant.Proc.; 12: 107-114, 1980.

72. McIntire, K.R., Vogel, C.L., Primack, A., Waldmann, T.A., Kyalwazi, S.K.

Effect of surgical and chemotherapeutic treatment on alpha-fetoprotein levels in patients with hepatocellular carcinoma.

Cancer; 37: 677-683, 1976.

73. MacNab, G.M., Alexander, J.J., Lecatsas, G., Bey, E.M., Urbanowicz, J.M.

Hepatitis B surface antigen produced by a human hepatoma cell line.

Brit.J.Cancer; 34: 509-515, 1976a.

74. MacNab, G.M., Urbanovicz, J.M., Geddes, E.G.

Hepatitis B surface antigen and antibody in Bantu patients with primary hepatocellular carcinoma.

Brit J. Cancer; 33: 544-548, 1976 b.

75. Marion, P.L., Salazar, F.H., Alexander, J.J., Robinson, W.S.

Polypeptides of hepatitis $B$ wirus surface antigen produced by a hepatoma cell line.

J.Virol.; 32: 796-802, 1979.

76. Marion, P.L., Salazar, F.H., Alexander, J.J., Robinson, W.S.

Site of hepatitis B viral DNA in human hepatocellular carcinoma cell line.

J. Virol.; 33: 795-806, 1980.

77. Matsumoto, Y., Suzuki, T., Ono, H., Nakase, A., Honjo, I.

Evaluation of hepatoma chemotherapy by alpha-fetoprotein determination.

Amer.J.Surg.; 132: 325-328, 1976.

78. Matsumura, $\mathrm{H}$.

Primary cultured cells and an established cell line of human hepatocellular carcinomas.

Acta Med.Okayana; 37: 341-352, 1983.

79. Maupas, Ph., Melnick, J L. 
Hepatitis $B$ infection and primary liver cancer.

Prog.Med.Virol.; 27; 1-5, 1981.

80. Maertel, C.G.

The Liver.

In: Cancer Medicine; 1774-1781.

Eds. : Holland, J.F, Frei, E.

Lea and Febiger, Philladelphia, 1981.

81. Moldofsky, Ph.J., Sears, H.F., Mulhern, Ch.B., Hammond, N.D., Powe, J., Gatenby, R.A., Steplewski, Z., Koprowsky, H.

Detection of metastatic tumor in normal-sized retroperitoneal lymplh nodes by monodonal antibody imaging.

N.Engl.J.Med;; 311: 106-107, 1984.

82. Monjardino, J.P., Fowler, M.J., Thomas, H.C.

Defective hepatitis $B$ virus DNA molecules detected as a stable integration pattern in a hepatoma cell line and in induced tumours and derived cell lines.

J.Gen. Virol.; 64: 2299-2303, 1983.

83. Mori, W., Machiami, R., Tanaka, K.

Pathology of hepatocellular carcinoma.

Path.Res.Pract.; 169: 4-20, 1980.

84. Murray-Lyon, I.M.

Primary and secondary cancer of the liver.

In: Carcinoma of the liver, biliary tract and pancreas: $1-82$.

Ed.: Gazet, J.C.;

Edward Arnold, 1983.

85. Nayak, N.C., Dhar, A., Sachdeva, R., Mittal, A., Seth, H.N., Sudarsanam, D., Reddy, B., Wagholikar, U.L., Reddy, C.R.

Association of human hepatocellular carcinoma and cirrhosis with hepatitis B virus surface and core antigens in the liver.

Int.J.Cancer; 20: 643-654, 1977.

86. Obata, H., Hayashi, N., Okuda, K., Nishioka, K.

Continuous monitoring of HBsAg and alpha-fetoprotein in patients with cirrhosis and detection of hepatocellular carcinoma in an early stage.

Hepatitis Sci.Memo H-881, Buffalo, Calspan, 1975.

87. Okita, K., Kodama, T., Harada, T.

Early lesions and development of primary hepatocellular carcinoma in man - Association with hepatitis B viral infection.

Gastroenterol Jpn.; 12: 52-57, 1977.

88. Okuda, K., Nakashima, T.

Hepatocellular Carcinoma: A Review of the Recent Studies and Developments.

In: Progress in Liver Diseases; 639-650.

Eds. Popper H., Schaffner, F.

Grume and Stratton, 1979.

89. Okuda, $\mathrm{K}$.

Primary liver cancer in Japan.

Cancer; 45: 2663-2669, 1980.

90. Okuda, K., Mackay, I.

Chemical hepatocarcinogenesis.

UICC Technical report Series; 74: 94-107, 1982.

91. Okuda, K., Obata, H., Nakajima, Y., Ohtsuki, T., Okazaki, N., Ohnishi, K.

Prognosis of primary hepatocellular carcinoma.

Hepatology; 4: 3S-6S, 1984.

92. Oladapo, J.M., Goodall, A.H., Parmar, J., Koning, R.W. de, Brown, D., Thomas, H.C.

In vitro and in vivo cytotoxic activity of native and ricin conjugated monoclonal antibodies to $\mathrm{HBs}$ antigen for Alexander primary liver cell carcinoma cells and tumours.

Gut; 25: 619-623, 1984. 
93. Olweny, C.L., Katongole-Mbidde, E. Bahendeka, S., Otim, D., Mugerwa, J., Kyalwazi, S.K.

Further experience in treating patients with hepatocellular carcinoma in Uganda.

Cancer; 46: 12: 2717-2722, 1980.

94. Pailesen, G., Jepsen, F.L., Hastrup, J, Ipsen, A., Hwidberg, N.

Experience with the Oxford tumour marker (Call) in serous fluids.

Lancet; $1: 1326,1983$.

95. Paradinas, F.J., Melia, W.M., Wilkinson, M.L. Portmann, B.. Johnson, P.J., Murray-Lyon, I.M., Williams, R.

High serum witamin $\mathrm{B} 12$ binding capacity as a marker of the fibrolamellar variant of hepatocellular carcinoma.

Brit.Med.J.; 285: 840-842, 1982.

96. Peacocke, I., Amos, B., Laszlo, J.

The detection of iso-antigens on leukemic cells using the cytotoxicity test.

Blood; 28: 665-673, 1966.

97. Peyrol, S., Grimaud, J.A., Chayvialle, J.A., Veyre, B., Paliard, P., Lambert, R.

Tissular immunoenzymatic detection of hepatic alpha-fetoprotein in human hepatomas.

Digestion; 18: 351-370, 1978.

98. Pollack, M.S., Heagney, S., Fogh, J.

HLA typing of cultured human tumor cell lines: the detection of genetically appropriate HLA-A,

$B, C$, and DR alloantigens.

Transplant.Proc.; 12: 134-137, 1980.

99. Popper, H., Skin, J.W.K., Gerin, J.L.

Woodchuck hepatitis and hepatocellular carcinoma: correlation of histologic with virologic observations.

Hepatology; 1: 91-98, 1981.

100. Preliminary communication.

A report from the Hammersmith Oncology Group and the Imperial Cancer Research Fund.

Antibody-guided irradiation of malignant lesions.

Three cases illustrating a new method of treatment.

Lancel; : $1444-1443,1984$.

101. Ruoslahti, E., Seppala, M.

Alpha-fetoprotein in cancer and fetal dewelopment.

Adv. Cancer Res.; 29: 275-346, 1979.

102. Sakaguchi, $\mathbf{K}$.

Hepatocyte plasma membrane antigens. I. Determination of antibodies bound to the hepatocyte plasma nembrane by 125 I-protein A binding assay.

Gastroenterol.Jpn.; 18:330-338, 1983.

103. Shafritz, D.A., Kew, M.C.

Identification of integrated hepatitis $B$ wirus DNA sequences in human hepatocellular carcinoma.

Hepatology; 1: 1-8, 1981 .

104. Sherlock, S., Fox, R.A., Niazi, S.P.

Chronic liver disease and primary liver-cell cancer with hepatitis-associated (Australia) antigen in serun.

Lancet; 1: $1243-1247,1970$.

105. Shinagawa, T., Ohto, M., Kimura, K., Tsunetomi, S., Morita, M., Saisho, H., Tsuchiya, Y., Saotone, N., Karasawa, E., Miki, M., Ucno, T., Okuda, K.

Diagnosis and clinical features of small hepatocellular carcinoma with emphasis on the utility of real time ultrasonography.

Gastroenterology; 86: 495-502, 1984.

106. Shouwal, D., Reid, L.M., Chakraborty, P.R.

Tumorigeneity in nude mice of a human hepatoma cell line containing hepatitis B virus DNA.

Cancer Res.; 41: 1342-1350, 1981.

107. Shouval, D., Wands, J.R., Zurawski, V.R., Isselbacher, K.J., Shafritz, D.A.

Selective binding and complement mediated lysis of human hepatoma PLC/PRF/5 cells in culture by monoclonal antibodies to hepatitis $B$ surface antigen. 
Proc.Natl.Acad.Sci. USA; 79: 650-654, 1982a.

108. Shouval, D., Shafritz, D.A., Zurawski, V.R., Isselbacher, K.J., Wands, J.R.

Immunotherapy in nude mice of human hepatoma using monoclonal antibodies against hepatitis B virus.

Nature: 298: $567-569,1982 \mathrm{~b}$.

109. Skelly, J., Copeland, J.A., Howard, C.R., Zuckermann, A.J.

Hepatitis B surface antigen produced by a human hepatoma cell line.

Nature; 282: 617-618, 1979.

110. Smith, J.B., O'Neill, R.T.

Alpha-fetoprotein occurrence in germinal cell and liwer malignancies.

Amer.J.Med.; 51: 767-771, 1971.

111. Stannard, L.M., Alexander, J., Saunders, R.M., Alexander, J.J.

Electron microscopy of HBsAg from human hepatoma cell line.

Lancet; 2: 713-714, 1977 .

112. Starzl, T.E., Koep, L.J., Halgrimson, G.G.

Fifteen years of clinical liver transplantation.

Gastroenterology; $77: 375-388,1979$.

113. Summers, J.

Three recently described animal virus models for human hepatitis $B$ virus.

Hepatology; 1: 179-183, 1981.

114. Sung, J.L., Chen, D.S.

Maternal transmission of hepatitis B surface antigen in patients with hepatocellular carcinoma in Taiwan.

Scand.J.Gastroenterology; 15: 321-324, 1980.

115. Szmuness, W.

Hepatocellular carcinoma and the hepatitis B virus. Evidence for a causal association.

Prog.Med.Virol.; 24: 40-69, 1978.

116. Tabor, E., Copeland, J.A., Mann, G.F., Howard, C.R., Skelly, J., Snoy, P., Zuckerman, A.J., Gerety, R.J.

Nondetection of infectious hepatitis $B$ virus in a human hepatoma cell line producing hepatitis $B$ surface antigen.

Intervirology; 15: 82-86, 1981.

117. Tatarinov, Y.S.

Detection of embryo-specific alpha-globulin in the blood sera of patients with liver tumour.

Vop.Med.Khim. (Moskva); 10: 90-91, 1964.

118. Terry, W.B.

Organ specific cancers. Primary cancer of the liver.

nn: Cancer in China: 101-1.11.

Eds. Kaplan, H.S., Tsuchitani, P.J.

Alan R. Liss, New York, 1978.

119. Thomas, H.C., Lin, K.C., Sherlock, S.

Alpha-fetoprotein concentrations in liver disease: early diagnosis of hepatocellulat carcinoma.

In: Alpha-fetoprotein in clinical medicine.

Eds. Weitzel, H.K., Schneider, J.

Thieme Verlag, Stuttgart, 1979.

120. Thung, S.N., Gerber, M.A., Sarno, G., Popper, H.

Distribution of five antigens in hepatocellular carcinoma.

Lab.lnvest .; 41: 101-104, 1979.

121. Ting, C.C., Herberman, R.B.

Humoral host defense mechanisms against tumours.

Int.Rev.Exp.Pathol.; 15: 93-152, 1976.

122. Tock, E.P.C., Shanmugaratnam, K.

Epidemiology of primary liver cancer in Singapore.

Ann.Acad.Med.Singapore; 9: 193-195, 1980.

123. Twist, E.M., Clark, H.F., Aden, D.P., Knowles, B.B., Plotkin, S.A. 
Integration paltern of hepatitis B virus DNA sequences in human hepatoma cell lines.

J. Virol.: 37 : 239-243, 1981 .

124. Uchida, T., Shikata, T., Kaneda, $H$.

Histopathology study of hepatocellular carcinoma in relation to liver cirrhosis and hepatitis B virus. Act.Hepat.Jap.; 19: 1063-1076, 1978.

125. Wiedmann, K.H., Trejdosiewicz, L.K., Thomas, H.C.

Identification of membrane antigens expressed on primary liver cancer (PLC) cells but not on normal untransformed hepatocytes (abstract).

Hepatology; 3: 865, 1983.

126. Wogan, G.N.

The induction of liwer cell cancer by chemicals.

In: Liver Cell Cancer: 121-152.

Eds. Cameron, H.M., Linsell, D.A., Warwick, G.P.

Elsevier Scientific Publishing Company, 1976.

127. Zeng, Y., Gong, C.H., Jan, M.G., Fun, Z., Zhang, L.G., Li, H.Y.

Detection of Epstein Barr virus $\lg \mathrm{A} / \mathrm{Ea}$ antibody for diagnosis of nasopharyngeal carcinoma by immunoautoradiography.

Int.J.Cancer; 31: 599-601, 1983.

128. Zhaoyou, $T$.

Screening and early treatment of primary liver cancer - with special reference to the east part of China.

Ann.Acad.Med.Singapore; 9: 234-239, 1980. 


\section{CHAPTER II}

\section{Autoantibodies in liver disease}

The immune system is undoubtedly thought to be responsible for the hepatocellular injury in several liver diseases, but the precise immunopathological mechanisms and the involved target antigens have not been fully identified. In viral hepatitis viral antigens expressed on the hepatocellular membrane are thought to be instrumental in the injury to the hepatocyte, because no evidence for direct viral cytopathic action has been found. Since hepatocellular injury frequently progresses without demonstrable viral antigens, however, it has also been suggested that hepatocyte surface membrane antigens might be relevant targets for an autoimmune response.

Normally the regulatory mechanisms of the immune system permit responses to foreign antigens but suppress those directed to autologous components. Nevertheless, transient autoimmune responses do occur in normal subjects and only when prolonged, these represent a pathological state (Thomas, 1979). The possible mechanisms of deficient immune-regulatory systems in chronic liver disease are unclear. In these conditions, especially in cirrhosis, an increased production of antibodies to enteric organisms has been demonstrated. This has been attributed to inability of the malfunctioning liver to sequester antigens from the portal blood.

Antibodies to some non-enteric organisms, notably measles and rubella viruses, have been found in extremely high titres in chronic active hepatitis, without evidence of recent infection (Triger, 1972). So far a full explanation has not been provided but $B$ cell hyperreactivity could play a role, possible due to a lack of $T$ cell feedback control.

Associations between specific types of chronic liver disease and specific autoantibodies have been established. Of these autoantibodies mitochondrial, smooth muscle and antinuclear antibodies are the best characterized.

\subsection{AUTOANTIBODIES TO NON-ORGAN-SPECIFIC ANTIGENS}

2.1.1. Antimitochondrial antibody (AMA) was first recognized by Mackay (1958) using a complement fixation technique. Using immunofluorescence Walker (1965) showed that sera of patients with primary biliary cirrhosis $(\mathrm{PBC})$ preferentially reacted with cells rich in mitochondria. The antibodies appeared to react specifically with mitochondrial antigens (Berg, 1967). AMA may concern all immunoglobulin classes, but is mostly IgM (Paronetto, 1967, Feizi, 1968). AMA has a unique relationship with PBC, being found in over 95 percent of patients (Thomas, 1979). The antigen is located on the inner membrane of the mitochondrion (Berg, 1967) and was shown to be a lipoprotein with a molecular weight of about 200.000 daltons. No organ specificity was found. AMA was also demonstrated in patients with chronic active hepatitis 
and cryptogenic cirrhosis (Doniach, 1966). Heterogeneity of mitochondrial antibodies has been demonstrated by Sayers (1979) and Miyachi (1980). Separation of mitochondrial membranes into inner membranes, outer membranes, intermembrane space proteins and matrix proteins revealed four antigenic specificities. In the heterogenous group of antimitochondrial antibodies six different specificities have been separated and characterized (Berg, 1981). Based on these findings different diseases could be differentiated. Anti- $\mathrm{M}_{2}$, directed against an antigen of the innermitochondrial membrane, was present in PBC and cholestatic chronic active hepatitis. The latter cases had, in addition, a second antimitochondrial antibody (anti- $\mathbf{M}_{4}$ ), which fixed complement with a trypsin insensitive antigen, probably located on the outer mitochondrial membrane (Berg, 1980). Manns (1982) established a radioimmunoassay directed against one determinant of a mitochondrial antigen which bears the characteristics of the primary biliary cirrhosis antigen $\left(\mathrm{M}_{2}\right)$. Although the rellation of the latter antigen to the etiology and pathogenesis of PBC is unclear, this study clearly improved the standardisation of the serological diagnosis of PBC.

2.1.2. Smooth muscle antibody (SMA), when detected in high titre, occurs in up to $70 \%$ of the patients and therefore is closely associated with chronic active hepatitis (Johnson, 1965). It was subsequently found that low titres of SMA may occur in a wide variety of other liver diseases and also in the normal population with a prevalence ranging from 3 percent (Hooper, 1972) to 14 percent (Holborow, 1973). The antigen has been tentatively identified as smooth muscle actomyosin. Holborow (1972) detected an antigen on or closely related with the hepatocyte plasma membrane which cross-reacts with the smooth muscle antibody.

The reactivity of sera of patients with chronic active hepatitis (CAH) with bile canaliculi (Diederichsen, 1969) has been attributed to SMA, reacting with cell-surface actomyosin (Kurki, 1980). Hamlyn (1980) showed that in acute hepatitis increased antiactin titres did not occur, whereas occasionally smooth muscle antibody was present in low titre. This finding implies that IgM-SMA found in acute hepatitis (Farrow, 1970) is not specific for actin. Three different immunofluorescent staining patterns with SMA positive sera on frozen sections of rat kidney have been described : SMA-T (tubules), SMA-G (glomeruli) and SMA-V (vessels) (Bottazzo, 1976). The reactivity of SMA-V could not be neutralized by actin. This is an additional indication that nonactin specific SMA exists. Nevertheless, in the majority of instances of SMA in chronic liver disease actin appears to be the antigen (Hamlyn, 1980).

2.1.3. Antinuclear antibodies (ANA) are also frequently associated with chronic active hepatitis (Doniach, 1972). The nuclear staining pattern is usually diffuse in chronic active hepatitis and the antibodies are usually of IgG class. ANA occur much less frequently in PBC. ANA do not share the ubiquitous nature of SMA and are distinctly unusual in acute viral hepatitis. Antibodies to native double-stranded DNA occur in CAH, although infrequently (Davis, 1975). In contrast a high incidence of reactivi- 
ty to denatured single stranded DNA was found (Koffler, 1969). Recently Czaja (1983) demonstrated that these autoimmune features did not identify a subcategory of $\mathrm{HBs} \mathrm{Ag}$ negative chronic active hepatitis with a different clinical behaviour.

\subsection{AUTOANTIBODIES TO LIVER SPECIFIC ANTIGENS}

\subsubsection{Liver specific protein (LSP)/antibody to LSP}

Many investigators have attempted to identify liver specific antigens on hepatocytes and alterations in these antigens in hepatocellular disease prompted by the presence of liver membrane reactive antibodies in the serum. Meyer zum Büschenfelde (1972) was the first to describe two liver specific antigens in supernatants of human liver cell homogenates. Immunofluorescent studies indicated that one (LPII) occurred in the hepatocyte cytoplasm, while the other (LPI) was an unstable high molecular weight lipoprotein occurring in the hepatocyte surface membrane (Meyer zum Büschenfelde, 1972; Doniach, 1974; Jensen, 1983). Antisera to these proteins were induced in rabbits. Repeated immunization of rabbits induced inflammatory lesions in the liver resembling chronic active hepatitis in man (Meyer zum Büschenfelde, 1974). Similar abnormalities were demonstrated by Kuriki (1983) in mice after immunization with syngeneic liver-specific lipoprotein. McFarlane (1977) purified LPI, and called the purified component liver specific protein (LSP). Manns (1980) provided evidence that human LSP has species-specific and species-non-specific determinants. Applying the monoclonal antibody technique Lambert (1984) confirmed the presence of species cross-reactive antigenic determinants in LSP. The organ specificity of LSP was challenged by Behrens (1979), who found a close similarity to kidney fractions in gel filtration chromatographic patterns. Riisom (1983) and Murakami (1984) demonstrated organ non-specific antigenic determinants in LSP. It appears therefore that LSP contains multiple antigenic specificities, the identification of which depends to a large extent on the method of preparation. The monoclonal antibody technique may permit a more refined identification of different antigenic determinants in LSP. Jensen (1978) developed a radioimmunoassay for the detection of antibodies to LSP (antiLSP). He reported humoral immune reactivity to LSP in sera of patients with HBsAg positive and negative chronic active and persistent hepatitis as well as in sera of patients with acute viral hepatitis. Applying a different radioimmunoprecipitation technique for detection of anti-LSP, Kakumu (1979) also found anti-LSP in sera of patients with PBC. He observed that in cases of acute viral hepatitis progressing to chronic active hepatitis (CAH) anti-LSP remained positive and predicted development of $\mathrm{CAH}$ before the diagnosis could be made histologically. However, anti-LSP was also demonstrated in sera of patients with autoimmune disease not primarily involving the liver (Gerber, 1980; Manns, 1980b).

Using antibodies raised against LSP preparations it has been shown that LSP also occurs on human HCC (PLC/PRF/5) cells (Lebwohl, 1981; Sakaguchi, 1983). It was 
suggested that PLC/PRF/5 cells may serve as a source of homogenous LSP for further characterization and purification (Lebwohl, 1981). This may be a fruitful approach because many test systems for detection of anti-LSP use antigens of different degrees of purification. Further purification and characterization of antigenic determinants of LSP would greatly facilitate the development of uniform diagnostic assays.

\subsubsection{Liver membrane antibody}

The search for circulating liver membrane antibodies (LMA) (Meyer zum Büschenfelde, 1984) was revived by the finding of membrane-fixed IgG on hepatocytes isolated from rabbits with experimentally induced chronic active hepatitis (Hopf, 1974) as well as from patients with chronic inflammatory liver diseases (Hopf, 1975a). Hopf (1976) showed two distinct immunofluorescence patterns on surface membranes of viable hepatocytes of sera from patients with chronic active hepatitis. A linear pattern was observed with sera of patients with HBsAg negative chronic active hepatitis. In these sera liver membrane autoantibodies (LMA) usually occurred, giving a characteristic linear fluorescence pattern on membranes of isolated rabbit hepatocytes. In contrast, patients with HBsAg positive chronic active hepatitis and some patients with protracted acute HBV hepatitis displayed granular hepatocyte surface IgG deposits in the absence of LMA. A large clinical trial (Tage-Jensen, 1977) confirmed the close correlation between the presence of LMA and HBsAg negative chronic inflammatory liver disease. Subsequently LMA were also detected in few cases of $\mathrm{HBs} A \mathrm{~g}$ positive $\mathrm{CAH}$, PBC, alcoholic liver disease (ALD) and drug induced liver disease (Schuurman, 1982; Eggink, 1982; Burt, 1982; Meliconi, 1983b). In contrast, Gluud (1983) did not find differences between alcoholic liver disease and controls in the prevalence of LMA. Meliconi (1983a) observed that linear as well as granular fluorescence patterns of in vivo bound IgG can be found in different liver diseases. He could not establish consistent crosscorrelations between the two fluorescence patterns of $\mathrm{IgG}$ (granular and linear) and the occurrence of LMA and anti-LSP. Therefore the antigen specificity of the in vivo bound immunoglobulins remains obscure. Anyhow, LMA are most consistently associated with HBsAg negative CAH (Eggink, 1982) especially when present at high titre (Meliconi, 1983b). Apart from being more specific for autoimmune liver disease than organ-non-specific autoantibodies the LMA assay increases the diagnostic yield of autoantibody assays, e.g. in HBsAg negative $\mathrm{CAH}$ from 77 to 92 percent (Schuurman, 1982).

\subsubsection{Heterogeneity of liver membrane antibodies}

The target antigens of LMA are still unknown. After the problem of stabilization and radiolabelling of the very unstable LSP was solved (McFarlane, 1977) and a specific and sensitive radioimmunoassay for detection of antibodies to LSP (anti-LSP) was 
developed, it was initially suggested that LMA resemble anti-LSP (Hopf, 1975b; Jensen, 1978). However, Meyer zum Büschenfelde (1979a) demonstrated that sera of patients with CAH contain LMA which can not be absorbed by LSP. No correlation was found between anti-LSP and LMA (Manns, 1980a; Meliconi, 1983a). Evidently therefore, the LMA assay detects antibodies of an antigen different from the antiLSP' assay (Manns, 1980b; Meliconi, 1983a).

LMA can be found independently of SMA (Tage-Jensen, 1980). Using affinity chromatography the LMA associated antigen was isolated and was designated liver membrane antigen (LM-Ag). This antigen seems to be species-unspecific. By cross immuno-electrophoresis LM-Ag appears to be clearly distinct from LSP (Meyer zum Büschenfelde, 1979b). Manns (1980a) established a radioimmunoassay for LMA and observed no correlation of LMA with SMA, ANA and AMA.

The monoclonal antibody technique may in the future allow affinity purification and further characterization of LM-Ag. Appropriately purified antigenic preparations might result in standardized and more reliable LMA detection assays.

So far LMA have been only demonstrable on single cell suspensions. The absence of liver cell membrane staining on tissue sections has remained unexplained (Eggink, 1982). Recently, however, Lee (1983) showed the importance of fixation procedures for antigenic sites. Prior Bouin's fixation of cryostat sections abolished most of the fluorescence due to ANA, AMA and SMA but resulted in brilliant fluorescence of rat hepatocyte membranes with sera of patients with CAH and PBC.

Hepatocytes of different species have been used in the LMA assay with varying results. Frazer (1983) obtained $70 \%$ sensitivity and $95 \%$ specificity in the diagnosis of autoimmune $\mathrm{CAH}$ using monkey hepatocytes as substrate in an immunoradiometric assay for IgG class autoantibody to liver membrane antigens. Conceivably the use of hepatocyte suspensions of higher primates (preferably even of man) may increase the sensitivity of the procedure for detection of liver cell membrane antibodies.

\subsection{DESIGN OF THE STUDY: PLC/PRF/5 CELLS AS A SUBSTRATE FOR THE DETECTION OF LIVER MEMBRANE ANTIBODIES}

Data in the literature and our own investigations indicated that PLC/PRF/5 cells are well differentiated and therefore antigenically closely related to normal hepatocytes. Human hepatocytes as substrate for the detection of liver membrane reactive antibodies potentially allow the detection of antibodies directed against species specific antigens. We therefore compared an experimental immunofluorescence assay using PLC/PRF/ 5 cells for the detection of liver membrane reactive autoantibodies with the established LMA assay on rabbit hepatocytes. In addition flowcytometry was applied for quantitative and objective analysis. 


\subsection{REFERENCES}

1. Behrens, U.J., Paronetto, F.

Studies on Liver-specific antigens 1. Evaluation of the liver specificity of LSP and LP-2.

Gastroenterology: 77: 1045-1052, 1979.

2. Berg, P.A., Doniach, D. Roilt, 1.M.

Mitochondrial antibodies in primary biliary cirthosis.

J.Exp. Med.; 126: 277-290, 1967.

3. Berg, P.A., Wiedmann, K.H., Sayers, T., Klöppel, G., Lindner, H.

Serological classification of chronic cholestatic liver disease by the use of two different types of antimitochondrial antibodies.

Lancet; 11: 1329-1332, 1980.

4. Berg, P.A., Homberg, J.C., Bottazzo, G.F., Doniach, D.

Clinical significance of mitochondrial antibodies in relation to liwer disease (letter).

Lancet; 11: 804, 1981.

5. Bottazzo, G.F., Florin-Christensen, A, Fairfax, A.

Classification of smooth muscle autoantibodies detected by immunofluorescence.

J.Clin. Pathol.; 29: 403-410, 1976.

6. Burt, A.D., Anthony, R.S., Hislop, W.S., Bouchier, I.A.S., MacSween, R.N.M.

Liver membrane antibodies in alcoholic liver disease: 1 . prevalence and immunoglobulin class.

Gut; 23: 221-225, 1982 .

7. Czaja, A.J., Davis, G.L., Ludwig, J., Baggenstoss, A.H., Taswell, H.F.

Autoimmune features as determinants of prognosis in steroidtreated chronic active hepatitis of uncertain etiology.

Gastroenterology; 85: 713-717, 1983.

8. Davis, P., Read, A.E.

Antibodies to double-stranded (native) DNA in active chronic hepatitis.

Gut; 16: 413-415, 1975.

9. Diedericksen, $H$.

Hetero-antibody against bile canaliculi in patients with chronic, clinically active hepatitis.

Acta Med.Scand.; 186: 299-302, 1969.

10. Doniach, D., Roitt, I.M., Walker, J.G., Sherlock, S.

Tissue antibodies in primary biliary cirrhosis, active chronic hepatitis, cryptogenic cirrhosis and other liver diseatses and their clinical implications.

Clin.Exp.Immunol.; 1: 237-262, 1966.

11. Doniach, D., Walker, J.G.

Immunology of liver disease.

In: Progress in Liver Diseases; 4: 385-397.

Eds:: Popper, H., Schaffner, F.

New York, Grune and Stratton, 1972.

12. Doniach, D., Walker, J.G.

Progress report.

Mitochondrial antibodies (AMA).

Cut; 15: 664-668, 1974 .

13. Eggink, H.F., Houthoff, H.J., Huitema, S., Gips, C.H., Poppena, S.

Are liver membrane antibodies important in the pathogenesis of chronic active liver disease?

Liver; $2: 818,1982$.

14. Farrow, L.J., Holborow, E.J., Johnson, C.O.

Autoantibodies and the hepatitis-associated antigen in acute infective hepatitis.

Brit.Med.J.; 2: 693-695, 1970.

15. Feizi, $T$.

Immunoglobulins in chronic liver disease.

Gut: 9: 193-198,

16. Frazer, I.H., Kronborg, I.J., Mackay, I.R.

Antibodies to liver membrane antigens in chronic active hepatitis $(\mathrm{CAH})$. II. Specificity for autoimmune CAH. 
Clin.Exp.Immunol.; 54: 213-218, 1983.

17. Gerber, M.A., Lebwohl, N., Thung, S.N.

Liver-specific protein: how specific is it?

In: Frontiers in Liwer Disease; 139-143.

Eds.: Berk and Chalmers, 1980.

18. Gluud, C., Tage-Jensen, $U$.

Autoantibodies and immunoglobulins in alcoholic steatosis and cirrhosis.

Act.Med.Scand.; 214: 1: 61-66, 1983.

19. Hamlyn, A.N., Berg, P.A.

Haemagglutinating anti-actin antibodies in acute and chronic liver disease.

Gut; 21: 311-317, 1980 .

20. Holborow, E.J.

Smooth muscle autoantibodies, viral infection and malignant disease.

Proceedings of the Royal Society of Medicine; 65: 481-484, 1972.

21. Hopf, U., Meyer zum Büschenfelde, K.H., Arnold, W.

Detection of a liwer membrane autoantibody in HBsAg-negative chronic active hepatitis.

N.Engl.J.Med.; 294: 578-582, 1976.

22. Holborow, E.J.

Smooth muscle autoantibodies in infectious mononucleosis.

Brit.Med.J.; 3: 323-325, 1973.

23. Hooper, B., Whittingham, S., Mathews, J.D.

Autoimmunity in a viral community.

Clin.Exp.Immunol; 12: 79-87, 1972.

24. Hopf, U., Meyer zum Büschenfelde, K.H.

Studies on the pathogenesis of experimental chronic active hepatitis in rabbits. II. Demonstration of immunoglobulin on isolated hepatocytes.

Brit.J.Exp.Pathol.; 55: 509-513, 1974.

25. Hopf, U., Arnold, W., Meyer zum Büschenfelde, K.H.

Studies on the pathogenesis of chronic inflammatory liver diseases.

I. Membrane-fixed IgG on isolated hepatocytes from patients.

Clin.Exp.Immunol.; 22: 1-8, $1975 \mathrm{a}$.

26. Hopf, U., Meyer zum Büschenfelde, K.H., Arnold, W.

Detection of a cytophilic autoantibody in chronic active hepatitis.

Lancet; 1: 690-691, 1975b.

27. Jensen, D.M., McFarlane, I.G., Portmann, B.S., Eddleston, A.L.W.F., Williams, R.

Detection of antibodies directed against a liver-specific membrane lipoprotein in patients with aculte and chronic active hepatitis.

N.Engl.J.Med.; 299: 1-7, 1978.

28. Jensen, D.M., Hall, C., Majewski, T.

The plasma membrane origin of liver-speciffe protein (LSP).

Liver; 3: 213-219, 1983 .

29. Johnson, G.D., Holborow, E.J., Glyson, L.E.

Antibodies to smooth muscle in patients with liwer disease.

Lancet; 11: 878-879, 1965 .

30. Kakumu, S, Arakawa, Y., Goji, H. Kashio, T., Yata, K.

Occurrence and significance of antibody to liver-specific membrane lipoprotein by double-antibody immunoprecipitation method in sera of patients with acute and chronic liver diseases.

Gastroenterology; 76: 665-672, 1979.

31. Koffler, D., Carr, R.ll, Agnello, V.

Antibodies to polynucleotides. Distribution in human serums.

Science; 166: 1648-1649, 1969 .

32. Kuriki, J., Murakami, H., Kakumu, S., Sakamoto, N., Yokochi, T., Nakashima, 1., Kato, N.

Experimental autoimmune hepatitis in mice after immunüzation with syngeneic liver proteins together with the polysaccharide of Klebsiella pneumoniae.

Gastroenterology; 84: 596-603, 1983. 
33. Kurki, P., Miettinen, A., Linder, E., Pikkarainen, P., Vuoristo, M., Salaspuro, M.P.

Different types of smooth muscle antibodies in chronic active hepatitis and primary billary cirrhosis: their diagnostic and prognostic significance.

Gut; 21: 878-884, 1980 .

34. Lamber, K.J., Major, G.N., Welsh, C.J.R., Ryall, J.E., McFarlane, I.G., Williams R.

Production and preliminary characterization of monoclonal antibodies to human liver-specific lipoprotein (LSP).

Liver; 4: 122-127, 1984.

35. Lebwohl, N., Gerber, M.A.

Characterization and demonstration of human liver-specific protein (LSP) and apo-LSP.

Clin. Exp.Immunol.; 46: 435-442, 1981 .

36. Lee, W.M., Shelton, L.L., Galbraith, R.M.

Antibodies to hepatocyte membrane antigens in chronic liver disease: detection by immunofluorescence after Brown"s fixation.

J.Histochem.Cytochem.; $31: 1246-1249,1983$.

37. McFarlane, I.O., Wojcicka, B., Zucka, A.M., Eddleston, A.L.W.F., Williams, R.

Purification and characterization of human liver specific membrane lipoprotein (LSP).

Clin Exp.Immunol.; 27: 381-390, 1977.

38. Mackay, I.R.

Primary biliary cirrhosis showing a high titer of autoantibody.

N.Engl.J.Med.; 258: $185-188,1958$.

39. Manns, M., Meyer zum Büschenfelde, K.H., Hütteroth, T.H., Hopf, U.

The liver specific protein: Evidence for species-specific and non-species-specific determinants.

J.Clin.Lab.Immunol.; 3: 9-13, 1980.

40. Manns, M., Meyer zum Büschenfelde, K.H., Hütteroth, T.H., Hess, G.

Detection and characterization of liver membrane autoantibodies in chronic active hepatitis by a solid-phase radioimmunoassay.

Clin.Exp.Immunol.; 42: 263-272, 1980a.

41. Manns, M., Meyer zum Büschenfelde, K.H., Hess, G.

Autoantibodies against liver specific membrane lipoprotein in acute and chronic diseases: studies on organ-, species- and disease specificity.

Gut; 21: 955-961, $1980 \mathrm{~b}$.

42. Marns, M.. Meyer zum Büschenfelde, K.H.

A mitochondrial antigen-antibody system in cholestatic liver disease detected by radioimmunoassay.

Hepatology: 2: 1-7, 1982.

43. Meliconi, R., Miglio, F., Stancari, M., Baraldini, M., Stefanini, G., Gasbarrini, G.

Hepatocyte membrane-bound IgG and circulating liver-specific autoantibodies in chronic liver disease: relation to hepatitis $B$ virus serum markers and liver histology.

Hepatology; 3: 155-166, 1983a.

44. Meliconi, R., Stancari, M., Garagnani, M., Baraldini, M., Stefanini, G.F., Miglio, F., Gasbarrini, $G$.

Occurrence and significance of $\mathrm{IgG}$ liver membrane autoantibodies (LMA) in chronic liver diseases of different etiology.

Clin.Exp.Immunol.; 51: 565-571, 1983b.

45. Meyer zum Büschenfelde, K.H., Miescher, P.A.

Liver specific antigens. Purification and characterization.

Clim Exp.Immunol ; 10: 89-102, 1972.

46. Meyer zum Büschenfelde, K.H., Hopf, U.

Studies on the pathogenesis of experimental chronic active hepatitis in rabbits. 1. Induction of the disease and protective effect of allogeneic liver specific proteins.

Brit.J.Exp.Pathol., 55: 498-508, 1974.

47. Meyer zum Büschenfelde, K.H., Manns, M.

Mechanisms of autoimmune liver disease.

Seminars in Liver disease; $4: 17-26,1984$. 
48. Meyer zum Büschenfelde, K.H., Manns, M., Hütteroth, T.H., Hopf, U., Arnold, W.

LMAg and LSP - two different target antigens involved in the immunopathogenesis of chronic active hepatitis?

Clin. Exp. Immunol.; 37: 205-212, 1979a.

49. Meyer zum Büschenfelde, K.H., Hütteroth, T.H. Arnold, W. Hopf, U.

Immunologic Liver Injury: The role of hepatitis B wiral antigens and liver membrane antigens as targets.

In: Progress in Liver Diseases, VI: 407-424.

Eds.: Popper, H., Schaffner, F.

Grune and Stratton, New York, $1979 \mathrm{~b}$.

50. Miyachi, K., Gupta "R.C., Dickson, E.R., Tan, E.M.

Precipitating antibodies to mitochondrial antigens in patients with primary biliary cirrhosis.

Clin.Exp.Immunol.; 39: 599-606, 1980.

51. Murakami, H., Kuriki, J., Kakumu, S., Fukui, K., Sakamoto, N.

The specificity of human liver membrane lipoprotein: studies with monoclonal antibodies.

Hepatology: 4: 192-198, 1984.

52. Paronetto, F., Schaffner, F., Popper, H.

Antibodies to cytoplasmic antigens in primary biliary cirrhosis and chronic active hepatitis.

J.Lab.Clin.Med.; 69: 979-988, 1967.

53. Riisom, $\mathbb{K}$., Diederickson, $\mathbf{H}$.

Demonstration of organ-nonspecific antigens in liver-specific protein.

Gastroenterology; 85: 1271-1276, 1983.

54. Sakaguchi, $\mathbb{K}$.

Hepatocyte plasma membrane antigens. I. Determination of antibodies bound to the hepatocyte plasma membrane by ${ }^{125}$ I-protein A binding assay.

Gastroenterol. Jpn; 18: 330-338, 1983.

55. Sayers, T., Binder, T., Berg, P.A.

Heterogeneity of anti-mitochondrial antibodies: characterization and separation of the antigen associated with the pseudo lupus erythematosus syndrome.

Clin.Exp.Immunol.; 37: 68-75, 1979.

56. Schutrman, H.J., Vogten, A.J.M., Schalm, S.W., Fevery, J.

Clinical evaluation of the liver cell membrane antibody assay.

Digestion; 23: 184-193, 1982.

57. Tage-Jensen, U., Arnold, W., Dietrickson, O., Hardt, F., Hopf, U., Meyer zum Buschenfelde, K.H., Nielsen, J.O.

Liver cell membrane autoantibody specific for inflammatory diseases.

Brit.Med.J.; 1: 206-208, 1977.

58. Tage-Jensen, U., Permin, H., Hardt, F., Juhl, E., Mathiesen, L.R., Nietsen, J.O., Ranek, L. Circulating astoantibodies in patients with acute viral hepatitis. Relation to etiology and clinical course.

Scand.J.Gastroenterol.; 15: 229-235, 1980.

59. Thomas, H.C., Jewell, D.P.

Autoimmune chronic active liver disease.

In: Clinical gastrointestitnal. inmunology, 211-227.

Blackwell Scientific Publications, 1979.

60. Triger, D.R., MacCallum, F.O., Kurtz, I.B., Wright, R.

Raised antibody titres to measles and rubella viruses in chronic active hepatitis.

Lancet; $1: 665-667,1972$.

61. Walker, J.G., Doniach, D., Roitt, I.M.

Serological tests in diagnosis of primary billiary cirrhosis.

Lancer; 1: 827-831, 1965. 


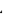




\section{CHAPTER III}

\section{Hepatitis B virus and host cell membrane antigens on a hepatocellular carcinoma cell line*}

\subsection{INTRODUCTION}

A better knowledge of the antigenic display of primary liver cell carcinoma cells will lead to a better understanding of the host/tumour interrelationship and also facilitate the development of specific reagents for diagnostic and immunotherapeutic procedures.

Recent publications have shown that the hepatocellular carcinoma cell line PLC/ PRF/5 (Alexander, 1976) contains the integrated hepatitis B virus genome (Brechot, 1980; Chakraborty, 1980; Edman, 1980; Shafritz, 1981) and secretes HB surface antigen (Monjardino, 1979). This tumour secretes alpha-fetoprotein when implanted in an athymic mouse (Bassendine, 1980) ańd also contains carcino-embryonic antigen (Gerber, 1981).

We have recently observed an increase in HLA Class 1 antigen display on hepatocytes during the HBe antibody positive phase of chronic HBV infection (Montano, 1982). In the present study we have examined the density and phenotype of HLA Class 1 proteins on the PLC/PRF/5 cell line.

Schrader (1975) showed functional interaction of viral and histocompatibility antigens at the tumour cell surface by demonstrating that patching and capping of the H2 antigens on the murine EL4 tumour cells resulted in the co-patching and cocapping of viral antigens. Callahan (1979) showed that an immuno-absorbent of insolubilized anti-murine lymphoma antibodies removed $\mathrm{H} 2$ antigens detectable in lymphoma extracts, but had no effect on $\mathrm{H} 2$ antigens in normal splenocyte extracts. This indicated a physical association of histocompatibility antigens and tumourassociated antigens on the surface of murine lymphoma cells. Because of these observations, we have examined the PLC/PRF/5 tumour cells by co-capping procedures to determine whether there is a physical association between the HLA proteins and viral antigens.

Division antigens are found on tumours which are rapidly dividing. One such antigen, which is now known to be the transferrin receptor, is identified by the monoclonal antibody OKT9 (Graeves, 1981). We therefore used this antibody to get further information on the antigenic make-up of the PLC/PRF/5 cell line.

* Published: Koning, R.W. de, Goodall, A., Varghese, Z., Thomas, H.C., Liver; 4: 1-6, 1984. 


\subsection{MATERIALS AND METHODS}

\subsubsection{Cell cultures}

PLC/PRF/5 cells were grown in MEM (Eagle) with Earle's salts, antibiotics and 1glutamine (Gibco Biocult Special) and $10 \%$ fetal calf serum at $37^{\circ} \mathrm{C}$ in humidified $5 \%$ $\mathrm{CO}_{2^{-}}-95 \%$ air with a medium change every 3 days and subcultured with a split ratio of 1:7. Tumour cells were harvested by trypsinization. The cells were washed twice with phosphate-buffered saline (PBS) and resuspended at $2 \times 10^{7}$ cells $/ \mathrm{ml}$ in PBS with $1 \%$ bovine serum albumin (PBSA). In general, the cells were used for fluorescence testing $1 \mathrm{~h}$ after harvesting. It appeared that after this period of reconstitution $100 \%$ of the cells showed surface labelling for HLA and $68 \%$ for HBsAg. Viability was tested by trypan blue exclusion. Only samples with more than $90 \%$ viability were accepted for further study.

\subsubsection{Immunofluorescence}

Indirect immunofluorescence was employed for the demonstration of antigenic determinants on the surface of the tumour cells. The cell suspension was aliquoted at a concentration of $10^{6}$ cells per $50 \mu \mathrm{l} \mathrm{PBSA}$. Ten $\mu \mathrm{l}$ mouse anti-HLA-ABC (W6/32) (monoclonal antibody against a common determinant; the specificity has been reported elsewhere (Barnstable, 1978)) was added and incubated for 30 min. at room temperature (RT).

After washing with PBSA the cells were resuspended and incubated with $10 \mu \mathrm{l}$ rhodamine-labelled goat anti-mouse $\mathrm{IgG}$ (adsorbed with human serum and mononuclear cells). The cell suspension was mounted on slides in PBSA with azide after a washing procedure. The preparations were examined without delay using a Leitz fluorescence microscope with an epilluminator system equipped with filter combinations for rhodamine and fluorescein. Normal mouse serum was used as a control and control preparations were consistently negative. The aliquoted cells were incubated with $5 \mu$ l neat anti-serum against HB surface antigen (Wellcome Foundation Ltd) for 30 min. (RT). After washing with PBSA, the cells were resuspended and incubated with $10 \mu \mathrm{l} 1 / 50$ diluted fluorescein-labelled goat anti-horse IgG (adsorbed with human serum and mononuclear cells) for $30 \mathrm{~min}$. at RT. After the final washing the cell suspension was mounted on slides in PBSA with azide. Normal horse serum was used as a control. Control preparations were consistently negative.

\subsubsection{Capping}

$10^{6} \mathrm{PLC} / \mathrm{PRF} / 5$ cells were incubated in $50 \mu \mathrm{l}$ PBSA with $5 \mu \mathrm{l}$ mouse anti-HLA$\mathrm{ABC}$ (W6/32) for $30 \mathrm{~min}$. at $4^{\circ} \mathrm{C}$. After washing with PBSA these cells were incubated with $10 \mu \mathrm{l}$ of the rhodamine-labelled goat anti-mouse IgG $\left(1 / 2\right.$ hour, $\left.4^{\circ} \mathrm{C}\right)$. After 
the final washing, the cells were left undisturbed with varying intervals for up to 60 min. at RT. Optimal capping was consistently found after $25 \mathrm{~min}$. After incubation with normal mouse serum, which served as a control, no fluorescence was found.

\subsubsection{Co-capping}

The previously described HLA-capped cells were incubated with the horse anti-HBs ( $1 / 2$ hour, RT) and after washing subsequently incubated with the fluorescein-labelled 1:10 diluted goat anti-horse $\operatorname{IgG}(1 / 2$ hour, RT). Normal horse serum, used as control, appeared to be negative. Rhodamine-labelled cells did not show fluorescein staining and therefore it was concluded that cross-reactivity of goat anti-horse $\mathrm{IgG}$ with mouse anti-HLA-ABC serum did not occur. Viability throughout the immunofluorescence procedure was not tested separately. However, nuclear fluorescence, which appears to be a reliable indicator of cell death, rarely occurred.

\subsubsection{OKT9 antigen display}

Ten $\mu 1$ of OKT9 antibody (Greaves, 1981) was incubated with $1.4 \times 10^{5} \mathrm{PLC} / \mathrm{PRF} /$ 5 cells ( 45 min., RT). Ten $\mu$ l of normal mouse serum served as a negative control. After washing with PBSA the cells were incubated in $10 \mu 1{ }^{125} \mathrm{I}$-labelled goat antimouse IgG (1:100) for $45 \mathrm{~min}$. (RT). After further washing the cells were harvested with the Titertek cell harvester and counted in a LKB (Wallac) 1280 Ultragammacounter.

\subsubsection{HLA Type 1 phenotyping}

Terasaki plates (Falcon 3034) were dispersed with $1 \mu$ aliquots of well-characterized antisera (Bristol $873 / 1$ and 2). Trays were first filled with liquid paraffin to prevent desiccation during storage at $-40^{\circ} \mathrm{C}$.

One $\mu$ l PBS containing $700 \mathrm{PLC} / \mathrm{PRF} / 5$ cells was added to each well of the plate and incubated at RT for $30 \mathrm{~min}$. Five $\mu \mathrm{l}$ of freshly thawed rabbit complement was added to each well and the plate incubated for a further hour. Staining was carriedl out with $2 \mu \mathrm{l} 5 \%$ aqueous eosin (BDM). For fixation, $5 \mu \mathrm{l}$ neutral formalin (BMD) was used. Numbers of dead cells were scored on a 4-grade scale.

\subsection{RESULTS}

With the indirect immunofluorescence assay, slightly granular membranous staining of HB surface antigen was seen in $68 \%$ of PLC/PRF/5 cells (Fig.1.). A slightly granular membranous fluorescence staining pattern of HLA-ABC antigens was obtained on all cells (Fig. 2.). Under capping conditions, as defined in the methods section, incubation of PLC/PRF/5 cells with anti-HLA-ABC (W6/32) resulted in mem- 


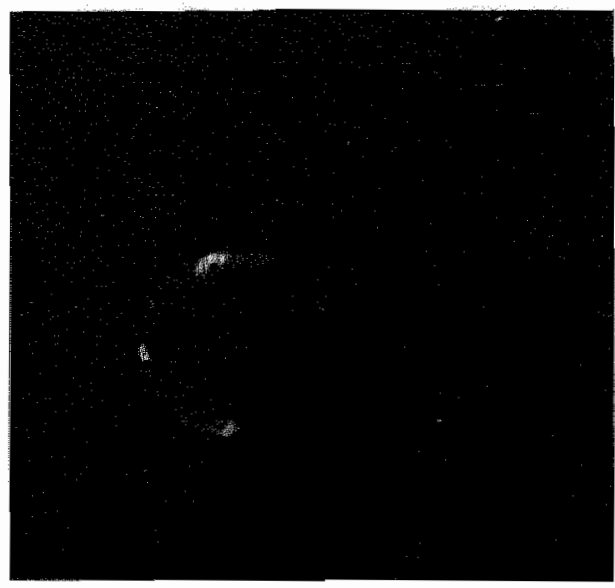

figure 1. PLC/PRl's cell incubated with horse anti-HB surface antiserum and stained with fluorescein-labelled goat antihorse $\mathrm{IgC}$.

Note: granular membranous staining pattern.

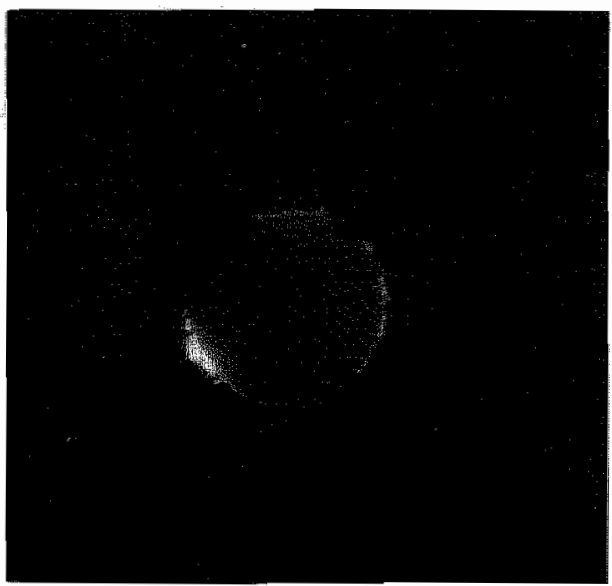

Figure 2. PLC/PRF/5 cell incubated with mouse anti-HLA-ABC antibody and stained with rhodamin conjugated anti-mouse $\operatorname{IgG}$.

Note: granular membranous staining pattern limmediately after incubation.

branous fluorescence in $70 \%$ of cells and an HLA cap in a maximum of $25 \%$ of cells. Capping did not develop synchronously in all cells. After prolonged periods of incubation of the cells before examination the total number of staining cells and the number of caps decreases, presumably due to shedding. Twenty-eight percent of
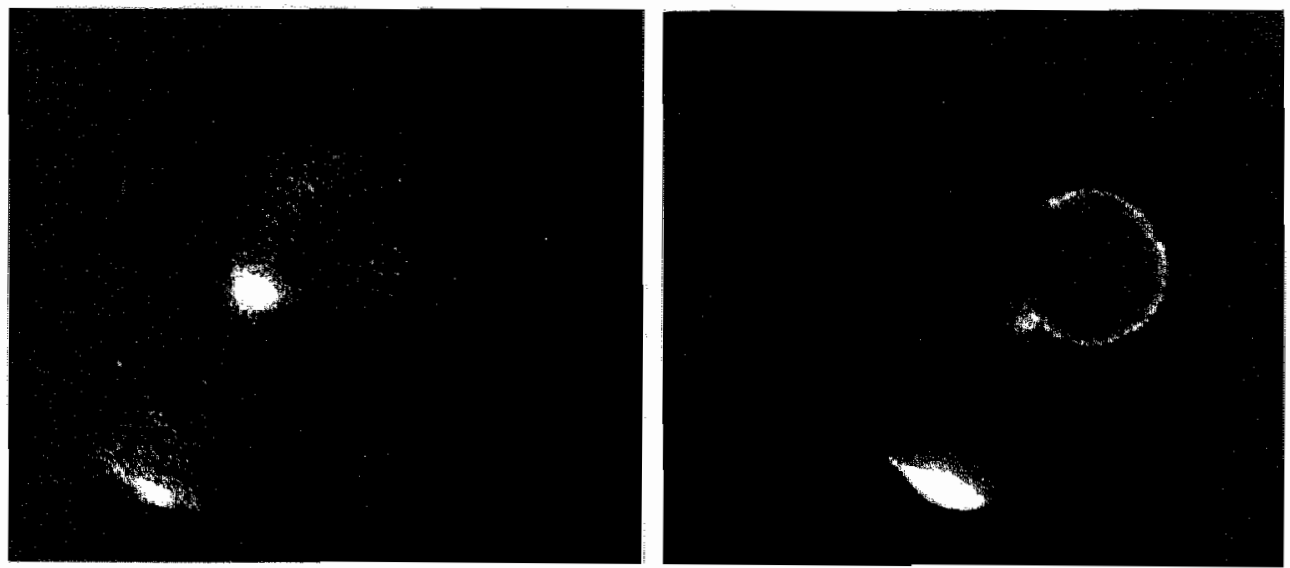

Figure 3. PLC/PRF/5 cells were stained, under capping conditions, for HLA-ABC antigens with rhodamin conjugated goat anti-nouse serum (left). The cells were then fixed and stained for HBs surface antigen with fuorescein conjugated goat anti-horse $\operatorname{lgG}$ (right).

Note: co-capping of HLA- and HBsAg-antigens. 
the capped cells appeared to be co-capping after staining with anti-HBs (Fig. 3.). Using $45 \mathrm{~A}$ locus and $74 \mathrm{~B}$ locus antisera, the HLA phenotype was A3, A26, B15, B16. There appeared to be weakly expressed additional antigens (11 and W19) at the A locus. However, particularly strong reactivity existed between A3 and A1I and between A 10 and AW19 and their respective splits or subgroups. The ratio of binding of OKT9 and normal serum to Alexander cells was 2:1 indicating the presence of OKT9 antigen.

\subsection{DISCUSSION}

In the normal human liver HLA Class 1 glycoprotein antigens are sparsely displayed on the hepatocytes in comparison to other liver cells such as the bile ductular, Kupffer and endothelial cells (Montano, 1982; Thomas, 1982). During the phase of active replication of the hepatitis B virus, there is no change in the HLA Class 1 antigens display on the membrane of the infected hepatocyte. However, when HBV particles have disappeared from the blood and $\mathrm{HBe}$ antibody has been produced, the infected hepatocytes show an increased HLA Class 1 antigen display (Montano, 1982). In the present study we have shown similarly increased HLA Class 1 antigen display on the membrane of a primary liver cell cancer line which contains the integrated HBV genome. The cause of this altered HLA antigen display is unknown. It has recently been demonstrated that interferon alpha results in an increased HLA Class 1 antigen display of exposed cells (Burrone, 1982), and it remains possible that this mechanism may be operative in HBe antibody positive carriers who have ceased to replicate the virus. Malignant transformation is also often associated with altered HLA antigen display, both changes in antigen density (Russell, 1979) and display of new HLA antigens (Pollack, 1980). In the present study there appeared to be an increase in density and expression of additional antigens at the A-locus. One of these may be a neoantigen expressed during malignant transformation. Alternatively, this could be an expression of a supertypic antigen because of shared minor specificities in the antisera used. Confirmation of this observation must await purification of the HLA proteins and further characterization.

Virus-induced tumours have been shown to express virus-coded structural antigens, tumour-specific antigens, altered HLA phenotypes, oncofetal antigens, and division antigens. In this paper we have confirmed the presence of the virus coded antigen HBs in the membrane of a majority of PLC/PRF/5 cells (Bassendine, 1980). In a minority of cells the capping of HLA antigen resulted in co-capping of HBs. A possible explanation is that, although in some cases the HBs antigen is part of the lipid membrane of the cell, in others it may be passively absorbed into the surface. The phenomenon of co-capping suggests that HBs antigen might be displayed near to and physically associated with the HLA protein. This observation is of considerable importance since the recognition of viral determinants by cytotoxic $\mathrm{T}$-cells is dependent on the display of foreign antigens in association with the HLA protein (Doherty, 1975). 
Some PLC/PRF/5 cells should therefore be susceptible to lysis by cytotoxic T-cells, specifically sensitised to HBs antigen. Cells in which HBs antigen is not associated with the HLA proteins would elude this surveillance mechanism and may outgrow other cells to become dominant in the tumour.

The PLC/PRF/5 cell line bears the OKT9 antigen which is present on many rapidly dividing normal and transformed cell lines.

This antigen is a division antigen. Recent studies have demonstrated that the antigen is in fact the transferrin receptor (Greaves, 1981). It is well established that rapidly dividing cells exhibit an enhanced display of this receptor protein (Greaves, 1981). In conclusion, we have established the patterns of expression of a number of relevant antigens on the membrane of primary liver cell carcinoma cells and we hope that this will lead to a better understanding of the host/tumour inter-relationship and also facilitate the development of specific reagents for diagnostic and immunotherapeutic procedures.

\subsection{SUMMARY}

We have defined some membrane antigens of the cultured thepatocellular carcinoma cell line PLC/PRF/5, which contains the integrated genome of hepatitis B virus. Using fluoresceinated antibodlies, we identified HLA Class 1 glycoprotein and HB surface antigen on the membrane. Only in a minority of cells physical association of these antigens was demonstrated by co-capping. The presence of a 'division' antigen was indicated by reactivity of the cells with the murine monoclonal antibody OKT9. 


\subsection{REFERENCES}

1. Alexander, J.J., Bey, E.M., Geddes. E.W., Lecatsas, G.

Establishment of a contimuously growing cell line from primary carcinoma of the liver.

S.Afr.Med.J.; 50: 2124-2128, 1976.

2. Barnstable, C.J., Bodmer, W.F., Brown, G., Galfre, G., Milstein, C., Willians, A.F., Ziegler, A. Production of monoclonal antibodies to group A erythrocytes, HLA and other human cell surface antigens. New looks for genetic analysis.

Cell; 14: 9-20, 1978.

3. Bassendine, M.F., Arborgh, B.A.M., Shipton, U., Thomas, H.C., Sherlock, S.

Hepatitis B surface antigen and alphafetoprotein secreting human primary liver cell carcinoma in athymic mice.

Gastroenterology; 79: 528-532, 1980.

4. Brechot, C., Pourcel, C., Louise, A., Rain, B., Tiollais, P.

Presence of integrated hepatitis B virus DNA sequences in cellular DNA of human hepatocellular carcinoma.

Nature; 286: 533-534, 1980.

5. Burrone, O.R., Milstein, C.

The effect of interferon on the expression of human cell surface antigens.

Interferon-twenty five years on; 133-135.

Proceedings of a Royal Society Discussion Meeting.

Eds.: Tyrrell, D.A.J., Burke, D.C., Royal Society, 1982.

6. Callahan, G.N., Allison, J.P., Pellegrino, M.A., Reisfold, R.A.

Physical association of histocompatibility antigens and tumour-associated antigens on the surface of murine lymphoma cells.

Int. J.Immunopharmacol; 122: 70-74, 1979.

7. Chakraborty, P.R., Ruiz-Opazo, N., Shouval, D., Shafritz, D.A.

Identification of integrated hepatitis B virus DNA and expression of viral RNA in an HBsAgproducing human hepatocellular carcinoma cell line.

Nature; 286: 531-533, 1980.

8. Doherty, P.C., Zinkernagel, R.M.

A biological role for the major histocompatibility antigens.

Lancet; 1: 1406- $1409,1975$.

9. Edman, J.C., Gray, P., Valenzuella, P., Rall, L.B., Rutter, W.J.

Integration of hepatitis $B$ wirus sequence and their expression in a human hepatoma cell.

Nature; $286: 535-538,1980$.

10. Gerber, M.A., Garfinkel, E., Hirschman, S.Z., Thung, S.N., Panagiotatos, T.

Immune and enzyme histochemical studies of a human hepatocellular carcinoma cell line producing hepatitis $\mathbf{B}$ surface antigen.

I.Immunol.; 126: 1085-1089, 1981.

11. Greaves, M., Delia, D., Sutherland, R.

Expression of the OKT monoclonal antibody defined antigenic determinants in malignancy.

Int J.Immunopharmacol.; 3: 283-300, 1981.

12. Monjardino, J., Crawford, $\mathbb{E}$.

Polypeptide profile of HBs antigen excreted by a human hepatoma cell line.

Virology; 96: 652 655, 1979 .

13. Montano, L.. Miescher, G.C. "Goodall, A.H., Wiedmann, K.H., Janossy, G., Thomas, H.C.

Hepatitis $B$ wirus and HLA antigen display in the liwer during chronic hepatitis $B$ virus infection.

Hepatology; 2: 557-561, 1982.

14. Pollack, M.S., Heagney, S., Fogh, J.

HLA typing of cultured human tumour cell lines: the detection of genetically appropriate HLA.A,

$B$ and DR alloantigens.

Transplantation Proceedings Reprint; 12: 134-137, 1980.

15. Russell, J.H., Gimno, L.C., Terres, G., Eisen, H.N.

Tumour antigens as inappropriately expressed normal alloantigens. 
J.Immunol: 122:912-919, 1979.

16. Schrader, J.W. Cunningham, B.A., Edelman, G.M.

Functional interactions of viral and histocompatibility antigens on tumour cell surface.

Proc.Nall.Acad.5ci.(USA); 72: 5066-5070, 1975.

17. Shafritz, D.A., Kew, M.C.

Identification of integrated hepatitis $B$ wirus DNA sequences in human hepatocellular carcinomas. Hepatology; $1: \mathbb{1}-8,198 \mathbb{1}$.

18. Thomas, H.C., Shipton, U., Montano, L.

The MLA system: its relevance to the pathogenesis of liver disease.

Progress in Liver Diseases VII: 517.527.

Eds.: Popper, H., Schaffner, $F_{*}$;

Grune and Stratton, New York, 1982. 


\section{CHAPTER IV}

\section{Induction and characterization of antibodies against PLC/PRF/5 cells.}

\subsection{INTRODUCTION}

Antigenic molecules present on tumour cell surfaces may include histocompatibilityantigens (Moller, 1964; Pearson, 1978; de Koning, 1984), tumour specific transplantation antigens (Prehn, 1957; Baldwin 1973; Klein, 1980), virus-associated antigens (Ledbetter, 1977; Gerber, 1981; de Koning, 1984) and embryonic antigens (Abelev, 1971; Chism, 1978).

One of the aims in tumour immunology is the characterization of antigenic determinants on the cell surface with as ultimate goal the production of tumour specific antibodies against tumour specific antigens for diagnostic and therapeutic purposes. In model animal systems, particularly the chemically induced tumours of rodents (Baldwin, 1973), tumour specific transplantation antigens have been conclusively identified. So far however, the evidence for the existence of tumour specific antigens in

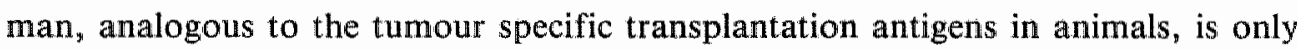
circumstantial. The natural history of certain tumours, the waxing and waning of tumourmasses and the occurrence of spontaneous regression suggests that there may be some host control - possibly immunological - of tumour growth (Everson, 1966). Similarly, the relationship between histological evidence of tumour infiltration by immuno-competent cells and prognosis suggests, that these infiltrating cells have some controlling influence on tumour growth (Bloom, 1970). Further circumstantial evidence comes from the increased incidence of certain malignancies in immunosuppressed patients. Production of specific antibodies against human tumours has not been particularly successful. If tumour specific antigens exist at all they are probably weak immunogens, which can be expected for cells which have effectively evaded the immunesystem of the host (Burnet, 1970). In this chapter we describe our attempts to induce specific antibodies against human hepatocellular carcinoma.

In an attempt to diminish the response against highly immunogenic non-tumour specific membrane antigens on tumour-cells (as e.g. histocompatibility antigens) in the production of tumour specific antibodies we have initially attempted to mask these antigens with antibodies prior to immunization. This was done by incubating $\mathrm{PLC} / \mathrm{PRF} / 5$ cells with polyclonal antibodies raised against normal human hepatocytes.

As this approach was not particularly successful we applied in a second attempt the hybridoma technology, developed by Köhler and Milstein (1975). This technique has already been applied to produce monoclonal antibodies specific for a variety of cellmembrane antigens including tumour associated antigens (TAA) of cultured human melanoma cells (Koprowski, 1978), human neuroblastoma-cells (Kennett, 1979), hu- 
man mammary tumour-cells (Colcher, 1981), human leiomyosarcoma-cells (Deng, 1981). Recently a general marker for human cancer-cells was reported to be detected by a monoclonal antibody raised against a cultured cell line derived from human laryngeal carcinoma (McGee, 1982). However the specificity of this monoclonal antibody has been seriously challenged (Simpson, 1983; Pallesen, 1983).

In this chapter we describe our recent experiences in the application of the methods outlined above for the study of antigens on a cultured human hepatocellular carcinoma (PLC/PRF/5) cell line. Antigens on this cell line have been fairly well documented (Thung, 1979; de Koning, 1984) and therefore this line seemed a suitable tool for the production of hepatocellular carcinoma specific antibodies.

\subsection{MATERIAL AND METHODS}

\subsubsection{Celltypes}

\subsubsection{PLC/PRF/5 cells}

These cells (Alexander, 1976) were grown in MEM (Eagle) with Earle's salts, antibiotics and L-glutamine (Gibco Biocult Special) and $10 \%$ fetal calf serum at $37^{\circ} \mathrm{C}$ in humidified $5 \% \mathrm{CO}_{2} 95 \%$ air with a medium change every 3 days and subcultured with a split-ratio of $1: 7$. Tumour cells were harvested by trypzinisation. The cells were washed twice with phosphate buffered saline (PBS) and resuspended at $2 \times 10^{7}$ cells $/ \mathrm{ml}$ in PBS with $1 \%$ bovine serum albumin (PBSA). In general the cells were used for testing purposes one hour after harvesting.

Viability was tested by trypanblue exclusion. Only samples with more than $90 \%$ viability were accepted for further study. These cells were used for immunization, radiolabelled aniglobulin tests and immunofluorescence assays as described below.

\subsubsection{Changwcells}

These cells were derived from a liverspecimen obtained during biopsy from a patient undergoing exploratory laparotomy (Chang, 1978). As to karyotype and isozyme pattern these cells have been indicted as a Hela-cell contaminant (Nelson-Rees, 1976). However Kaighn (1971) had found the Chang but not the Hela-cell capable of producing serum albumin and fibrinogen, while Hütteroth (1978) showed antigenic relationship between Chang livercells and human hepatocytes. Chang cells were kindly provided by Dr. John Monjardino. They were used for an immunofluorescence assay as decribed below.

\subsubsection{Daudi and Raji-cells}

These cells were kindly provided by Dr. George Janossy. They were originally deve- 
loped from Burkitt lymphomas: the Daudi cell line in 1963 (Pulfertaft) and the Raji cell line in 1967 (Klein, 1968). The cells were employed in radiolabelled antiglobulin assays as described below.

\subsubsection{Rat livercells}

Isolation of livercells from Sprague Dawley rats was performed by a modified perfusion technique (Kawanishi, 1979). The liver, cannulated at the portal vein, was perfused with $20 \mathrm{cc}$ Hank's solution with $7 \% \mathrm{NaHCO}_{3}$, which was free of calcium and magnesium and gassed with a mixture of $\mathrm{O}_{2}$ and $\mathrm{CO}_{2}$ (95:5) - solution I - with addition of $0,5 \mathrm{mMol}$ EDTA by means of a continuous flow perfusion pump (H.R.Flow inducer Watson-Marlow Ltd, Bucks, UK). After this perfusion $250 \mathrm{ml}$ of solution I was perfused followed by $50 \mathrm{ml}$ of the perfusion medium containing $0,1 \%$ collagenase and trypsin inhibitor (Sigma) - solution II - at a flow rate of about $18 \mathrm{ml} / \mathrm{min}$. at $37^{\circ} \mathrm{C}$ for approximately $20 \mathrm{~min}$. The perfused liver was removed and the tissue was incubated in solution II for $5 \mathrm{~min}$. at $37^{\circ} \mathrm{C}$ at $95 \% \mathrm{O}_{2} 5 \% \mathrm{CO}_{2}$ oxygenation under gently shaking. The cell suspension was passed through a nylon mesh by gravity. The cell suspension was spun at $600 \mathrm{rpm}$ during $2 \mathrm{~min}$. The sedimented cells were resuspended in $10 \mathrm{ml}$ of fresh medium consisting of minimal essential medium (MEM) with $20 \%$ heat-inactivated fetal calf serum, $2 \% .200 \mathrm{mM}$ L-glutamine, $1 \% 1 \mathrm{M}$ Hepesbuffer and antibiotics (Gibco). The viability of these isolated livercells was approximately $90 \%$ as determined by trypanblue exclusion. The cells were washed with PBSA before use in an immunofluorescence and a radiolabelled antiglobulin assay as described below.

\subsubsection{Human livercells}

According to Hütteroth (1978) a wedge biopsy of normal liver was cut into small pieces and teased by a needle in a solution of MEM (Eagle) with Earle's salts, antibiotics and $10 \%$ fetal calf serum at room temperature (RT). Afterwards the tissue was gently pushed through a mesh. The cell suspension was washed with PBSA before use in a radiolabelled antiglobulin assay as described below.

\subsubsection{Myeloma-line $\mathrm{P}_{3}-\mathrm{NS}_{t}$}

This is a non-secreting line, which synthesizes the kappa light chain only. The cells have been made hypoxanthine/aminopterin/thymidine (HAT)-sensitive by adaption to 8-azaguanine (Flow laboratories). Cells were routinely grown in Dulbecco's modification of Eagle's medium supplemented with pyruvate and $10 \%$ fetal calf serum as well as penicilline and streptomycine. The cells were subcultured $1: 3$ to $1: 4$ every 2-3 days. Seeding density was about $2-3 \times 10^{5} \mathrm{cells} / \mathrm{ml}$. 


\subsubsection{Membrane antigens of these cells}

Table I lists the expression of a number of $\mathrm{Ag}$ on the cells used as target for differential binding of the obtained anti PLC/PRF/5 antibodies. The information regarding the expression of major histocompatibility complex antigens and liver specific antigens was collected from the literature as indicated in the table.

Table 1. Antigen expression on cells used as target for differential binding of antibodies.

\begin{tabular}{llllll}
\hline Cells & Reference & HLA-ABC & Ia & LMAg & LSP \\
\hline Daudi & Klein 1968 & - & + & - & - \\
Raji & Pulfertaft 1964 & + & + & - & - \\
Human hepatocyte & Meyer z. Büschenfelde 1979 & \pm & - & + & + \\
Chang-cells & Hütteroth 1978 & \pm & - & + & + \\
Raut hepatocyte & Hopf 1974 & - & - & + & + \\
\hline
\end{tabular}

\subsubsection{Masking of human liver cell membrane antigens}

\subsubsection{Antiserum production for masking}

An antiserum against normal human livercells was prepared. Liver-biopsies were obtained from alcoholic patients and two wedge liverbiopsies from patients undergoing laparotomy. Informed consent was given. At histological examination the liverbiopsies appeared to be normal. The biopsies were cut into small pieces and teased by a needle in a solution of MEM (Eagle) with Earle's salts, antibiotics and 10\% fetal calfserum at roomtemperature (RT). Afterwards tissue was gently pushed through a mesh. The cellsuspension was washed with PBS before immunization. The cells were counted in a haematocytometer. Viability was less than $10 \%$ as determined by the trypanblue exclusiontest. About $10^{6}$ normal human livercells were injected intravenously into a New Zealand White (NZW) rabbit with boosting at 2, 4 and 5 weeks.

\subsubsection{Masking}

PLC/PRF/ 5 cell suspension $\left(10^{6}\right.$ cells $\left./ 50 \mu \mathrm{l}\right)$ were incubated on ice during 20 minutes with rabbit antiserum against normal livertissue in a volumeratio of 10:1. After 2 washings with PBS the cells were resuspended in $1 \mathrm{cc}$ PBS.

\subsubsection{Production of antiserum against PLC/PRF/5 cells $(\mathrm{R} \alpha \mathrm{A})$}

\subsubsection{Immunization}

A NZW rabbit was intravenously injected with about $0,5 \times 10^{7}$ 'masked' PLC/ PRF/5 cells. Booster injections were given after 3,4 and 5 weeks. 


\subsubsection{Production of hybridomas}

\subsubsection{Immunization}

In fusions 1-5 the $\mathrm{BALB} / \mathrm{c}$ mice were immunized intraperitoneally with about $0,5 \times 10^{7} \mathrm{PLC} / \mathrm{PRF} / 5$ cells, with two booster injections at 4 weeks intervals. The mouse providing serum with the highest number of counts in a radiolabelling assay for detection of antibodies against PLC/PRF/5 cells (see below) was boosted and the spleen was removed 5 days later.

In fusion 6 , mice were immunized with $0,5 \times 10^{7}$ cells intraperitoneally with boosting once at 2 weeks and a final booster-injection intravenously 10 days later. The spleen was removed under sterile conditions and teased with forceps in PBS with $2 \%$ fetal calf serum (FCS). The macerated tissue was triturated and afterwards whirlimixed for 30 seconds to disrupt possible clumps. After settling of residual clumps the supernatant with the cells was decanted. After washing, the cells were resuspended in serumfree culture medium and the number of viable cells was assessed.

\subsubsection{Fusion.}

A modified method of Galfre (1979) was used. $10^{8}$ Spleen cells from the immunized mouse were mixed with $10^{7}$ HAT-sensitive myeloma cells. The cells were centrifuged at $800 \mathrm{rpm}$ and supernatant was decanted. One ml 40\% (W/W) PEG 1500 (BDH) was added and incubated for exactly 7 minutes at $37^{\circ} \mathrm{C}$.

Thereafter the PEG was diluted gradually by adding equal volumes of serum-free medium until the PEG concentration was less than $5 \%$. The cellsuspension was centrifuged ( $800 \mathrm{rpm})$. After removing of supernatant 5 mil RPMI medium with $10 \% \mathrm{FCS}$ was added. After an incubation of $1 / 2$ hour at $37^{\circ} \mathrm{C}$ - to allow fusion to occur - the cells were dispensed into Linbro multiwell dishes (BCL-5041) at a cell density of $2 \times$ $10^{6}$ cells/well in $2 \mathrm{ml}$ HAT-medium. The HAT-medium was changed every day for the first few days and then at 2-3 days interval.

\subsubsection{Selection of hybrids}

By 7-14 days after the fusion the presence of clones of cells was evident. The supernatants were tested by a radiolabelled antiglobulin assay (see below). The cultures in the wells which showed a positive reaction were cloned, cultured continuously and, when there were enough cells, subcultured into larger bottles. As soon as antibody producing hybridomacells were obtained they were frozen in $90 \%$ FCS with $10 \%$ DMSO. 


\subsubsection{Antibody assay procedures}

\subsubsection{Immunofluorescence (IF) testing of antisera}

\subsection{IF on PLC/PRF/5 cells}

An indirect immunofluorescence test for the demonstration of antibody activity in the rabbit sera was employed. The PLC/PRF/5 cell-suspension was aliquoted at a concentration of $10^{6}$ cells per $50 \mu \mathrm{l}$ PBSA. Five $\mu 1$ neat rabbitserum was incubated (30 min., RT). After washing with PBSA we used $5 \mu$ goat anti-rabbit TRITC (Wellcome) as second layer after titration-testing. The cellsuspension was washed and mounted on slides. Without delay the preparations were examined using a Leitz fluorescence microscope with an epilluminator system equipped with a filtercombination for rhodamine.

Pre-immune rabbit-serum was used as a control; control preparations were consistently negative.

\subsection{IF on human hepatocytes}

A new technique was developed to increase the viability of normal human liver-cell suspensions, because for immunofluorescence testing cell suspensions of high quality are essential. A wedge liverbiopsy was slowly injected subcapsularly with a collagenase mixture ( $30 \mathrm{mg}$ collagenase type IV (Sigma) in $30 \mathrm{ml}$ Hanks medium oxygenated in an Erlenmeyer). Subsequently the liver was cut into small pieces with a pair of scissors and incubated for half an hour in the collagenase mixture in a humidified $5 \%$ $\mathrm{CO}_{2} 95 \%$ air incubator under intermittent shaking. The small tissue pieces were teased with two needles and $300 \mu \mathrm{D}$ DNA-ase $(0,01 \mathrm{mg} / \mathrm{ml}$ medium, Sigma) was added. For 5 minutes this mixture was gently shaken in an Erlenmeyer. The mixture was poured onto a nylon mesh and the cells were collected. The cell suspension was incubated twice during 2 minutes with $0,85 \% \mathrm{NH}_{4} \mathrm{Cl}$ in PBS solution. After washing with PBSA the viability of the cells appeared to be more than $95 \%$ as determined by the trypanblue exclusiontest. The immunofluorescence test procedure was performed as described at 4.2 .5 .1 .1 . using $10^{6}$ cells $/ 50 \mu \mathrm{PBSA}$.

\subsection{IF on lymphocytes}

Twenty ml venous blood were taken from a normal person and collected in a heparinized tube. Blood was carefully poured into a centrifuge tube on top of an equal volume of Ficoll. The tube was spun during 30 minutes in a Labofuge III centrifuge at $2000 \mathrm{rpm}$. The separated lymphocytes were collected and washed three times with MEM (Eagle's) with heparine. Aliquoted lymphocytes $\left(10^{6} / 5 \mu \mathrm{l}\right)$ were processed as indicated at 5.1.1. 


\subsection{IF on cryostatsections}

Liverbiopsies of patients with various liver diseases were snapfrozen in isopentane quenched in liquid nitrogen. Cryostatsections of $5 \mu \mathrm{m}$ thickness were prepared, air dried for 1 hour, successively fixed in cold acetone/chloroform $(50: 50 \mathrm{v} / \mathrm{v})$ during 4 minutes and lyophilized for $21 / 2$ hours. They were kept at $-70^{\circ} \mathrm{C}$ until use. Twenty $\mu 1$ of a 1:3 dilution of rabbitsera in PBS was layered on top of the section. Incubation was performed in a dark humid chamber (40 min., RT). After 10 munutes washing in PBS the section was incubated with $10 \mu$ goat anti rabbit TRITC (Wellcome) 1:10 diluted in PBS (40 min., RT). After washing the preparations were mounted with 50\% glycerol in PBS. Preimmunization rabbit serum used as control was consistently negative.

\subsubsection{Immunoperoxidase method on cryostatsections}

Immunoreactivity of the adsorbed rabbit anti PLC/PRF/5 serum was tested on frozen sections, postfixed in ethanol $96 \%$ (10 min., RT) of the following human tissues: normal adult glandular and mucosal epithelia; two ovarium carcinomata, two coloncarcinomata and a solid PLC/PRF/5 cell tumour grown in a nude mouse. Tissue sections were incubated in a $0.5 \%$ solution of hydrogen peroxide in methanol.

Sections were incubated with normal swine serum (1:5) for 10 minutes and then with the testsera 1:100 (30 min., RT). Sections were then exposed to swine anti-rabbit Ig 1:100 (Dako) for 30 minutes. After washing the section was incubated ( 30 min., RT) with horse radish peroxidase - rabbit anti peroxidase 1:500 (Dako). All dilutions were made in Tris buffer saline (TBS) (pH 7.6). Each step was followed by washing in TBS (three changes in 5 min.). Finally the sections were reacted with a diaminobenzidine substrate and counterstained with hematoxylin. Three observers read all slides independently; the results were in complete agreement.

\subsubsection{Radiolabelled antiglobulin assay}

The $\mathrm{F}(\mathrm{ab})_{2}$ fragment of goat anti-mouse IgG (kindly provided by Dr.George Janossy) was iodinated according to the procedure described by Morris (1975). $10^{5}$ Cells suspended in $50 \mu \mathrm{l}$ PBSA were incubated with $100 \mu$ of supernatant from lybrid cells for 1 hour (RT). After 2 washings with PBSA cells were incubated with $50 \mu \| 125$ goat anti-mouse $\operatorname{lgG}$ (diluted to about $10^{5} \mathrm{cpm}$ radioactivity). After 2 washings with PBSA cells were harvested with the Titertek cell harvester and radioactivity was counted in a LKB (Wallace) 1280 ultragammacounter. Three samples of HAT medium ser ved as negative control. The cutoff value was taken at two times the negative control mean. 


\subsubsection{Special radioimmunoassay}

The commercially available Ausab-test (Abbott) was used for detection of antibodies against $\mathrm{HBsAg}$, while the Corab assay (Abbott) was employed for detection of antibody against hepatitis B core antigen. A screening for antibodies against alpha-fetoprotein was performed by a competitive radioimmunoassay using the Hoechst kit.

\subsubsection{Adsorbtion of antiserum}

\subsubsection{Complement}

Heat inactivation of complement in the immune serum was performed during $30 \mathrm{mi}$ nutes in a waterbath at $56^{\circ} \mathrm{C}$.

\subsubsection{HBsAg}

HBsAg solution was dialyzed against distilled water for 16 hours at $4^{\circ} \mathrm{C}$. One gram of Sepharose $2 \mathrm{~K}$ was swollen with $10^{-3} \mathrm{M} \mathrm{HCL}$ on a rotamix for half an hour. The Sepharose was washed first over a glass filter with $10^{-3} \mathrm{M} \mathrm{HCL}$ and afterwards with $\mathrm{NaHCO}_{3}(\mathrm{pH} 8.4)$. Fifteen $\mathrm{ml}$ of the Sepharose was mixed with $250 \mu \mathrm{l}$ dialysed HBsAg on a rotamix for 16 hours at $4^{\circ} \mathrm{C}$. Subsequently the mixture was spun down (Labofuge III - $5000 \mathrm{rpm}$ for $5 \mathrm{~min}$.). After discarding the supernatant, glycine was added and mixed during 2 hours on a rollershaker (RT). The gel was poured into a glassfilter and washed three times successively with citrate buffer $(\mathrm{pH} 3)$ and $\mathrm{NaHCO}_{3}$ buffer ( $\mathrm{pH}$ 8.3). The last wash was with PBS with $0.05 \%$ azide. $0.6 \mathrm{~mL}$ of antiserum was mixed with the HBsAg-Sepharose gel overnight on a rollershaker $\left(4^{\circ} \mathrm{C}\right)$. The mixture was spun $(800 \mathrm{rpm}, 10 \mathrm{~min}$.). The supernatant was put into a wet Amicon ultrafiltrationmembrane cone and spun 55 minutes $(900 \mathrm{rpm})$.

\subsubsection{Protein content}

By a digital ultraviolet photospectrometer (Cecil CE 292) at wavelength $280 \mathrm{~nm}$ the proteincontent was determined.

\subsubsection{Blocking}

\subsubsection{Cellsuspensions}

The PLC/PRF/ 5 cell suspension was aliquoted at a concentration of $10^{6}$ cells per 50 $\mu \mathrm{l}$ PBSA. These cells were incubated with $10 \mu \mathrm{l}$ mouse anti-HLA-ABC (W6/32), an immunoglobulin against a common determinant of HLA-ABC (Barnstable, 1978). After washing with PBSA the immunofluorescence assay procedure mentioned at 4.2.5.1.1. was applied. 


\subsubsection{Cryostatsections}

Tissuesections were incubated with $10 \mu \mathrm{l}$ neat mouse anti-HLA-ABC (W6/32) in a dark chamber (30 min., RT). After a wash with PBS the indirect immunofluorescencetest was performed as mentioned under 4.2.5.1.4.

\subsection{RESULTS}

\subsubsection{The conventional approach}

When PLC/PRF/5 cells were incubated with anti-normal hepatocyte antiserum membrane fluorescence was obtained (Fig.1). Evidently PLC/PRF/5 cells shared membrane antigens with normal hepatocytes. Subsequently PLC/PRF/5 cells were incubated with this antiserum and with these cells another rabbit was immunized. The immune response was tested by incubating PLC/PRF/5 cells with immuneserum of this animal $(\mathrm{R} \alpha \mathrm{A})$. The highest antibody titer was obtained eight days after the third boosterinjection.

Table 2. Immunofluorescence of un-adsorbed and adsorbed rabbitsera anti-PLC/PRF/ 5 cell (RaA) on PLC/PRF/5 cells, normal human liver cells (NHL) and human lymphocytes.

\begin{tabular}{|c|c|c|c|c|c|c|}
\hline & \multicolumn{2}{|c|}{$\mathrm{PLC} / \mathrm{PRF} / 5$ cell } & \multicolumn{2}{|c|}{ NHL } & \multicolumn{2}{|c|}{ Lymphocyte } \\
\hline & intensity & cell $(\%)$ & intensity & cell $(\%)$ & intensity & cell $(\%)$ \\
\hline unadsorbe & & & & & & \\
\hline $\begin{array}{l}\mathrm{R} \alpha \mathrm{A} \\
\text { adsorbed }\end{array}$ & $+t+$ & 100 & ++ & 100 & +++ & 100 \\
\hline $\operatorname{R} \alpha A$ & + & 100 & $-\infty$ & 0 & \pm & 27 \\
\hline
\end{tabular}

Legends:

immunoreactivity: - negative

$+/ t+t+++$ weakly, moderately, strongly positive

Table 3. Immunofluorescence of adsorbed rabbitserum against PLC/PRF/5 cells on PLC/PRF/5 cells preincubated with anti-HLA-ABC antibodies (W6/32).

\begin{tabular}{ccc}
\hline & Immunofluorescence \\
Preincubation & intensity & cell $(\%)$ \\
\hline- & ++ & 100 \\
\hline+ & + & 76 \\
\hline
\end{tabular}

Legends:

immunoreactivity: - negative

+ weakly positive

++ strongly positive 


\subsubsection{Specificity testing}

By radioimmunoassay with this antiserum no reactivity against alpha-fetoprotein was detected. Neither was antibody against hepatitis B core antigen found. The Ausab test was positive (24 RIA units) indicating the presence of anti-HBsAg antibodies in our serum. After solid-phase adsorbtion with $\mathrm{HBsAg-Sepharose} \mathrm{immunoreactivity} \mathrm{with}$ HBsAg was no longer detected.

Immunofluorescence testing of our serum on human hepatocytes and human lymphocytes showed intense linear membrane reactivity (Table 2, Fig. 2 and 3). Therefore the antiserum was extensively adsorbed with human lymphocytes and liver homogenate. After this procedure reactivity was no longer found on normal hepatocytes. Only weak immunofluorescence remained on a small percentage of lymphocytes. Ad-

Table 4. Immunofluorescence of un-adsorbed and adsorbed rabbitserum anti-PLC/PRF/5 cells $(\mathrm{R} \alpha \mathrm{A})$ on a panel of human liver cryostatsections.

\begin{tabular}{|c|c|c|c|c|c|c|}
\hline $\mathrm{HCC}$ & NHL & $\mathrm{HFL}$ & ALD & $\begin{array}{c}\text { anti-HBe + } \\
\mathrm{CAH}\end{array}$ & $\begin{array}{l}\mathrm{HBsAg}+ \\
\text { cirrh. }\end{array}$ & $\begin{array}{c}\mathrm{HBsAg}- \\
\mathrm{HCC}\end{array}$ \\
\hline NRS & - & - & - & - & - & - \\
\hline unads. R $\alpha A$ & nd & nd & - & $+++* *$ & - & $+* *$ \\
\hline ads. $\mathrm{R} \alpha \mathrm{A}$ & $++*$ & $+*$ & - & $++4 * *$ & - & $+* *$ \\
\hline
\end{tabular}

Legends:

- NHL: normal human liver

- HFL : human fetal liver

- ALD: mild alcoholic liver disease

- CAH: chronic active hepatitis

- HCC: hepatocellular carcinoma

- NRS : normal rabbit serum

- immunoreactivity" - negative

$+1++/+++$ weakly, moderately, strongly positive

Table 5. Immunofluorescence of un-adsorbed and adsorbed rabbitserum anti-PLC/PRF/5 cells (RoA) on a panel of cryostatsections preincubated with anti-HLA-ABC-Ig (W6/32).

\begin{tabular}{lcccccc} 
& ALD & HFL & $\begin{array}{c}\text { anti-HBe } \\
\text { CAH }\end{array}$ & $\begin{array}{c}\text { HBsAgt } \\
\text { CAH }\end{array}$ & $\begin{array}{c}\text { HBsAg- } \\
\text { HCC }\end{array}$ & $\begin{array}{c}\text { solid } \\
\text { PLC/PRF/5 }\end{array}$ \\
\hline $\begin{array}{l}\text { NRS } \\
\text { unads. RF } \alpha A\end{array}$ & - & - & - & - & - & - \\
ads. R $\alpha A$ & nd & - & nd & nd & ++ & ++ \\
\hline
\end{tabular}

\section{Legends:}

- see table 4

- solid PLC/PRF/5-tumour grown in nude mouse. 


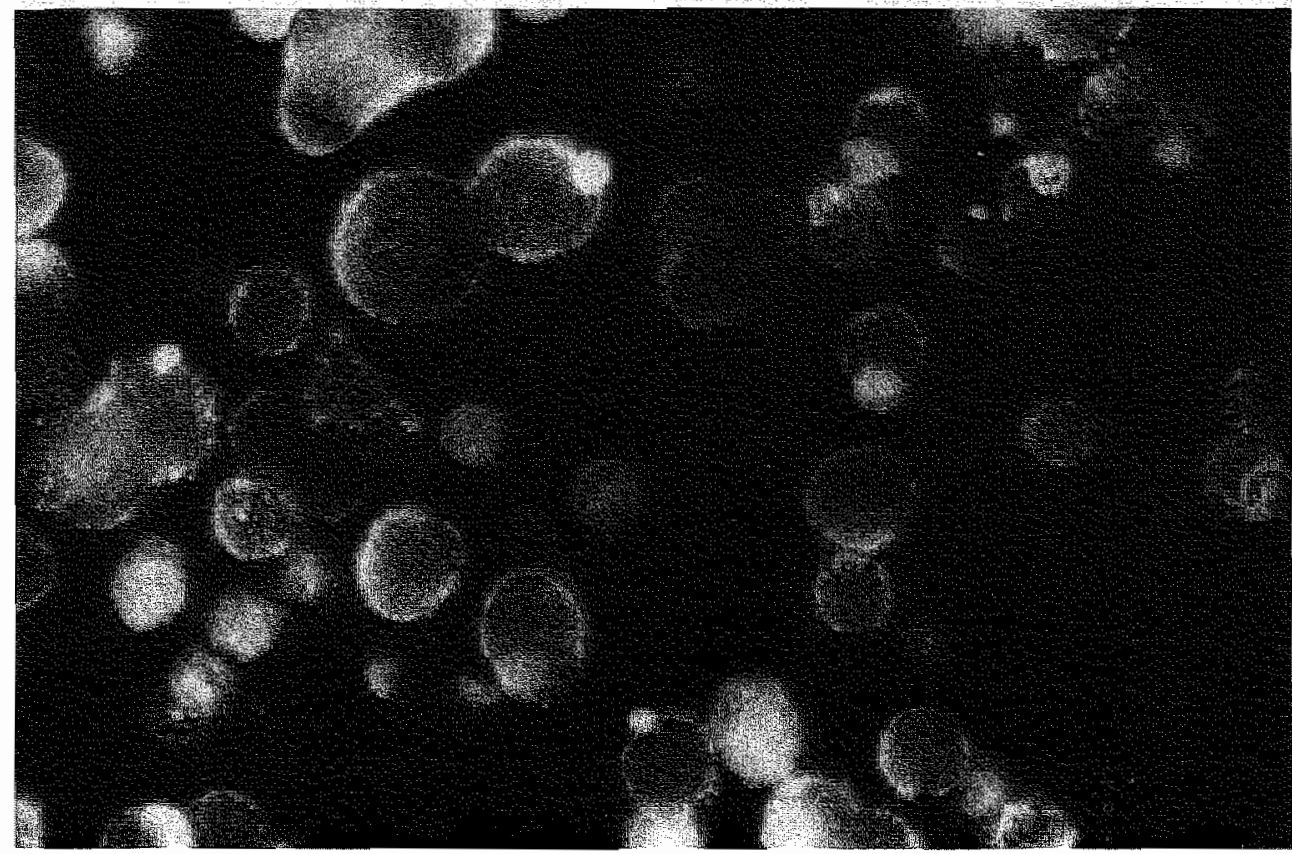

Figure 1. PLC/PRF/5 cells incubated with rabbit antiserum against normal humam liver cells and stained with thodamin conjugated anti-rabbut immunoglobulin.

Note: brilliant linear and locally microgranular surface membrane staining pattern.

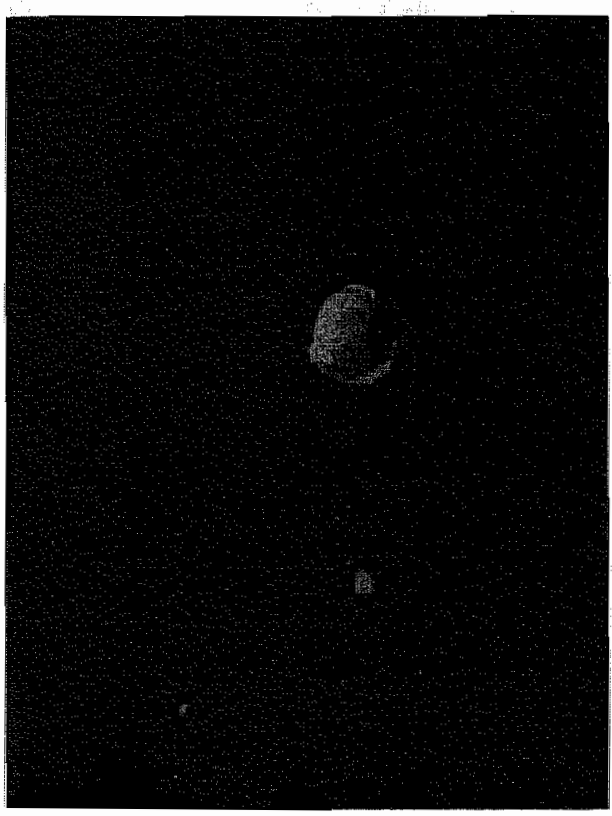

Figure 2. Normal human liwer cell incubated with unadsorbed rabbit antiserum against PLC/PRF/5 cells and stained with rhodamin conjugated anti-rabbit immunoglobulins.

Note: brilliant linear surface membrane staining pattern.

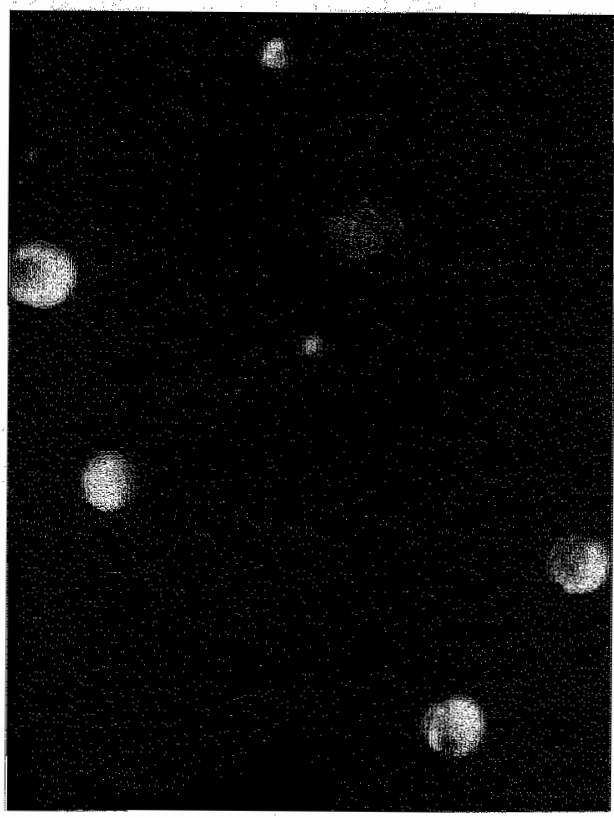

Pigure 3. Normal human lymphocytes incubated with unadsorbed anti-rabbit serum against PLC/PRF/5 cells and stained with rhodamin conjugated anti-rabbit immunoglobulins.

Note: brilliant lineur surface mem brane staining pattern. 


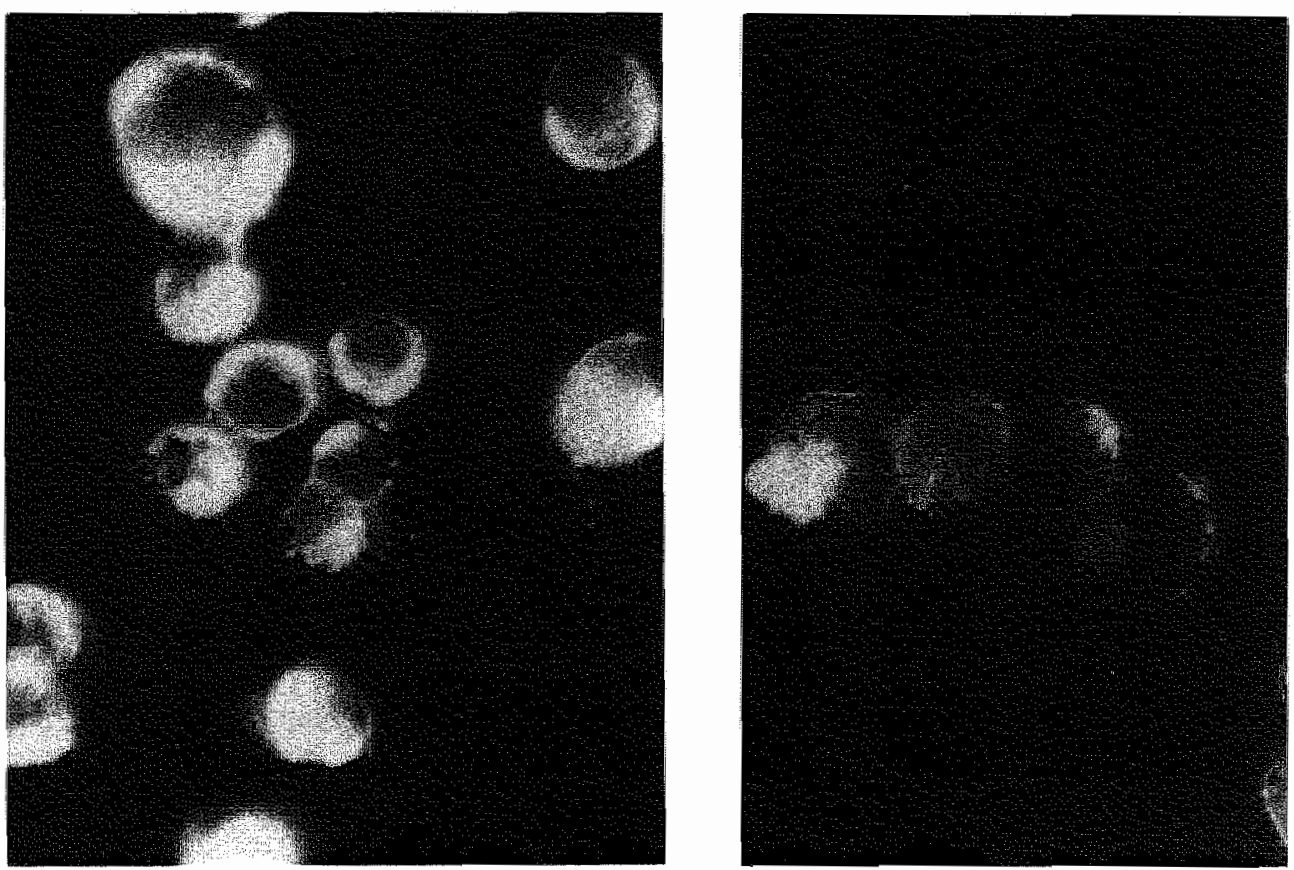

Figure 4, Left: PLC/PRF/5 cells incubated with unadsorbed rabbit antigerum against PLC/PRF/5 cells and stained with rhodamin conjugated anti-rabbit immunoglobulins.

Note: brilliant linear surface membrane staining pattern.

Right: PLC/PRF/5 cells incubated with adsorbed rabbit antiserum against PLC/PRF/5 cells and stained with rhodamin conjugated anti-rabbit immunoglobulins.

Note; weaker surface membrane staining than left side.

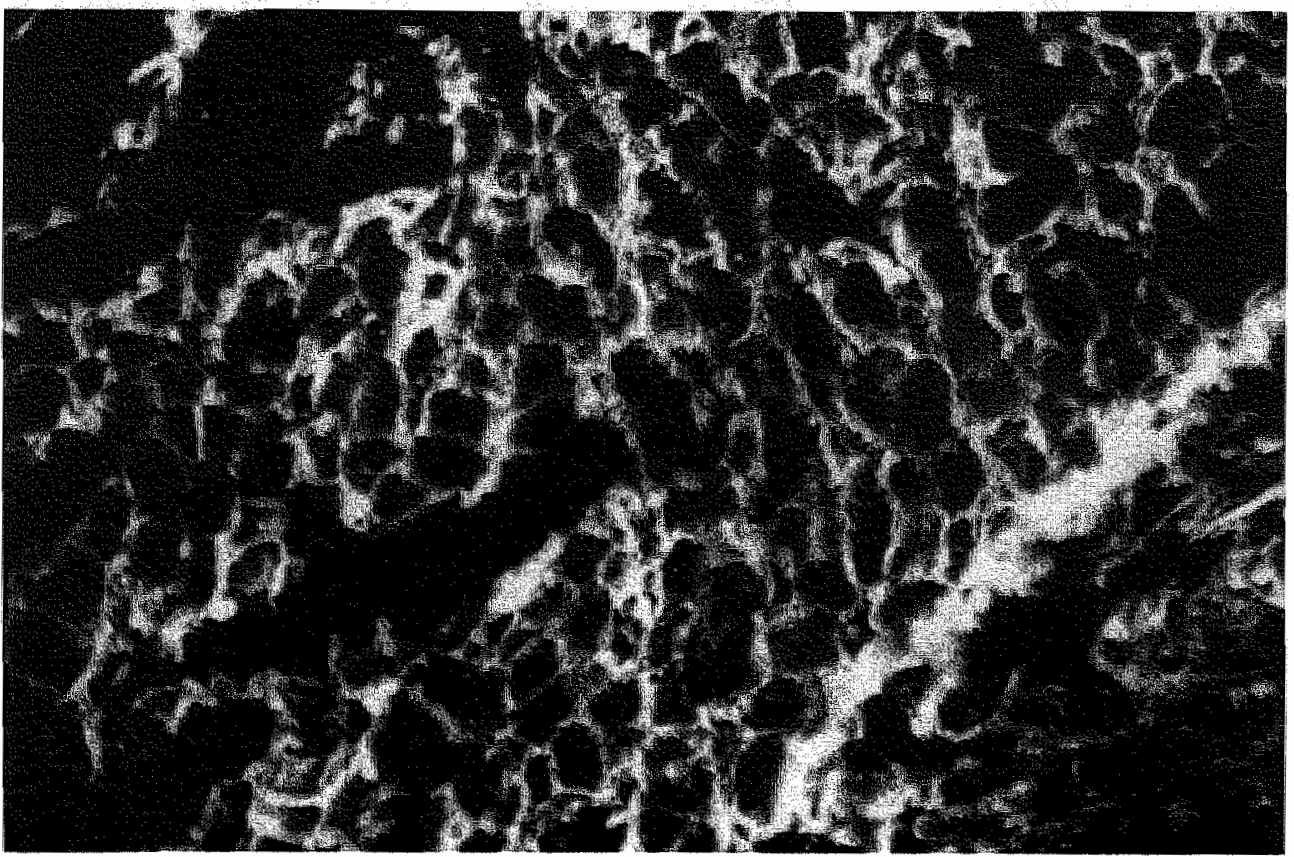

Figtare 5. Liver cryostatsection of HBeAb positive patient incubated with adsorbed rabbit antiserum agajnst PLC/PRF/S cells and stained with rhodamin conjugated anti-rabbit immunoglobulins. Note: parenchymal cell surface staining pattern. 
sorption decreased the antibody titer for PLC/PRF/5 cells from 1:32 to $1: 2$ (Fig.4) along with a decrease in protein content from 48.2 to $27.4 \mathrm{mg} / \mathrm{ml}$. After preincubation of PLC/PRF/5 cells with antibodies against a common determinant on HLA$\mathrm{ABC}$ partial blocking of immunoreactivity was observed (Table 3).

The adsorbed antiserum was subsequently tested by immunofluorescence on cryo-

Table 6. Immunoperoxidase stain of un-adsorbed and adsorbed rabbitserum anti-PLC/ $\mathrm{PRF} / 5$ cells $(\mathrm{R} \alpha \mathrm{A})$ on cryostatsections of various normal human adult glandular and mucosal epithelia.

\begin{tabular}{lrrll}
\hline & $\begin{array}{c}\text { unads. } \\
\text { R } \alpha \mathrm{A}\end{array}$ & $\begin{array}{c}\text { ads. } \\
\mathrm{R} \alpha \mathrm{A}\end{array}$ & pattern of reactivity \\
\hline solid PLC/PRF/5 & +++ & ++ & $\begin{array}{l}\text { cytoplasmic and membranous parenchymal; } \\
\text { locally with ads. R } \alpha \mathrm{A}\end{array}$ \\
liver & ++ & - & $\begin{array}{l}\text { membrane/cytoplasm parenchymal stain } \\
\text { pancreas }\end{array}$ \\
kidney & ++ & - & cytoplasm of ductal epithelium \\
adrenal & ++ & - & cytoplasm of tubuli \\
thyroid & ++ & - & $\begin{array}{l}\text { cytoplasm parenchymal cells } \\
\text { bladder } \\
\text { testis }\end{array}$ \\
prostate & ++ & - & cytoplasm epithelium \\
idem \\
\hline
\end{tabular}

Legends:

- NRS: normal rabbit serum was consistently negative

- immunoreactivity: - negative

+ weakly positive

++ moderately positive

+++ strongly positive

Table 7. Immunoperoxidase stain of un-adsorbed and adsorbed rabbitserum against PLC/ PRF/5 cells (R $\alpha \mathrm{A})$ on cryostatsections of several (adeno-) carcinomata.

\begin{tabular}{lrrl}
\hline & $\begin{array}{c}\text { unads. } \\
\text { R } \alpha A\end{array}$ & $\begin{array}{c}\text { ads. } \\
\text { R } \alpha A\end{array}$ & pattern of reactivity \\
\hline solid PLC/PRF/5 & +++ & ++ & $\begin{array}{l}\text { cytoplasmic and membranous parenchymal; } \\
\text { locally with ads. R } \alpha A\end{array}$ \\
ovarium I & ++ & - & $\begin{array}{l}\text { cytoplasm of epithelium } \\
\text { ovarium II }\end{array}$ \\
colonca I & +++ & ++ & $\begin{array}{l}\text { idem } \\
\text { colonca II }\end{array}$ \\
\hline
\end{tabular}

Legends: see table 6. 
statsections of a variety of normal and pathological liver tissues (Table 4). Normal adult and fetal human liver showed weak sinusoidal staining. Weak membrane staining was observed on tissue from a case of HBsAg negative hepatoma. Intense membrane staining was observed on a liver biopsy of a patient with anti-HBe positive chronic active hepatitis (CAH) (Fig. 5). After preincubation of cryostatsections with a mouse antibody against a common determinant on HLA-ABC, weak membranous

Table 8. Assays for antibody specificity testing.

\begin{tabular}{|c|c|c|c|c|c|c|c|c|c|c|}
\hline Code & $\begin{array}{c}\text { RA } \\
\text { PLC/ } \\
\text { PRE/S }\end{array}$ & $\begin{array}{c}\text { IF } \\
\text { PLC/ } \\
\text { PRF/s }\end{array}$ & $\begin{array}{l}\mathrm{RA} \\
\mathrm{Raji}\end{array}$ & $\begin{array}{c}\text { RA } \\
\text { Daudi }\end{array}$ & $\begin{array}{c}\text { RA } \\
\text { Rall } \\
\text { Liver- } \\
\text { cell }\end{array}$ & $\begin{array}{c}\text { RA } \\
\text { Human } \\
\text { Liver- } \\
\text { cell }\end{array}$ & $\begin{array}{c}\mathbb{I F} \\
\text { Chang }\end{array}$ & $\begin{array}{c}\text { IF } \\
\text { Cryostat } \\
\text { Human } \\
\text { Liver }\end{array}$ & $\begin{array}{c}\text { RA } \\
\text { Ausab }\end{array}$ & $\underset{\alpha A P}{R A}$ \\
\hline $1-28$ & 3,5 & 70 & + & -- & 3,5 & nd & nd & nd & - & nd \\
\hline $1-84$ & 3,5 & 30 & nd & - & 2 & nd & nd & nd & - & nd \\
\hline $1-90$ & 2,5 & - & - & - & 3,5 & nd & nd & nd & - & nd \\
\hline VI-7 & 9,2 & 55 & 4,5 & - & - & - & - & - & - & - \\
\hline VI-44 & 9,8 & 90 & 14,2 & - & - & nd & nd & $+*$ & - & nd \\
\hline$V_{1-45}$ & 10,4 & - & 19 & 2,1 & 3,3 & 1,6 & nd & nd & - & - \\
\hline VI-46 & 3,7 & - & 2,7 & - & - & nd & nd & nd & - & - \\
\hline VL -68 & 2,5 & - & - & nd' & - & nd & nd & nd & - & - \\
\hline VI-85 & 8,2 & - & 4,8 & 2,4 & - & - & nd & - & - & - \\
\hline VI-94 & 2,4 & - & 4,1 & 4,5 & - & 2,0 & - & - & - & - \\
\hline V1-113 & 5,7 & - & 6,3 & 3,0 & 2,9 & 2,1 & - & - & - & - \\
\hline$V I-133$ & 6,2 & 35 & - & nd & - & nd & nd & $+* *$ & - & - \\
\hline VI-142 & 8,6 & - & 10,5 & - & - & nd & nd & nd & - & - \\
\hline VI-148 & 3,0 & - & - & nd & - & - & nd & nd & - & - \\
\hline V1-157 & 6,4 & - & 3,2 & 5,4 & - & - & nd & nd & - & - \\
\hline VI-168 & 4,5 & - & - & nd & - & - & nd & nd & - & nd \\
\hline VI- 182 & 3,0 & - & 3,0 & - & - & $\dot{-}$ & nd & nd & - & - \\
\hline$V[-183$ & 13 & - & 6,7 & 3,0 & 3,1 & $\doteq$ & nd & nd & - & - \\
\hline VI-191 & 3,0 & - & - & nd & - & - & nd & nd & 2,4 & - \\
\hline VI-196 & 7,3 & 31 & - & nd & - & - & - & - & - & - \\
\hline VII.203 & 6,7 & - & 3,6 & 2 & - & - & nd & nd & - & - \\
\hline VII-207 & 4,5 & - & - & nd & - & - & nd & nd & - & - \\
\hline VI-219 & 4,6 & - & 2,9 & 2 & $\dot{-}$ & $\leq$ & nd & nd & nd & - \\
\hline VI-231 & 3,7 & - & 3,3 & 2,4 & - & - & nid & nd & - & - \\
\hline VI-232 & 5,4 & - & - & nd & - & - & nd & nd & - & - \\
\hline VI-235 & 3,1 & - & - & nd & - & 2,8 & - & - & - & - \\
\hline VI-236 & 3,7 & - & 2,9 & - & 2,5 & - & nd & nd & - & - \\
\hline
\end{tabular}

Legends:

- I and VI : first and sixth fusion

- RA : Radiolabelling assay; unit: multiplicator of negative control (cpm)

- IF : Immunofluorescence test; percentage of cells with membranefluorescence

- nd : not done

* sinusoidal staining pattern

* bilecanalicular staining pattern 
immunofluorescence remained only on tissue from a PLC/PRF/5 tumour, growin in a nude mouse, and on the liver tissue from the anti-HBe positive CAH case (Table 5). The serum was tested by the immunoperoxidase method on a variety of normal human tissues (Table 6). The unabsorbed antiserum showed intense reactivity with all tissues whereas the adsorbed antiserum showed traces of immunoreactivity with cytoplasm of urothelium and testicular parenchymal cells. On various adenocarcinomata bright cytoplasmic immunoreactivity was found in one case of ovarian cancer, while traces of cytoplasmic immunoreactivity were noted in 2 colonic carcinomas (Table 7 ).

\subsubsection{The hybridoma approach}

In the radiolabelled antiglobulin assay our first fusion resulted in 3 antibody producing clones after screening of 103 wells with growing hybridoma cells. Supernatants of two of these clones showed linear membrane-immunofluorescence on PLC/PRF/5 cells. Subsequent testing of these supernatants on a variety of cell types showed that cross-reactivity existed with rat hepatocytes (Table 8).

Subsequent fusions did not yield any useful monoclonal antibodies. Therefore a new immunizationscheme was introduced with shorter intervals between boosterinjections. A 6th fusion with splenocytes from a mouse immunized according to this scheme resulted in 89 hybridoma containing wells of which 28 secreted PLC/PRF/5 reactive antibodies. In four of these clones antibody production decreased over 3 weeks. The specificity tests of the supernatants of the remaining 24 clones are summarized in table 8. The supernatant of 15 clones crossreacted with Raji and/or Daudi-cells. With 4 of these supernatants reactivity was detected on rabbit hepatocytes. Two supernatants, VI-7 and VI-44, showed bright membrane immunofluorescence of PLC/PRF/5 cells. Immunofluorescence studies on cryostatsections of normal human livertissue showed a sinusoidal staining pattern with the supernatant of clone VI-44 (Fig.6).

The supernatant of clone VI-191 showed reactivity in the Ausab radioimmunoassay, indicating that the corresponding epitope belonged to the hepatitis B surface antigen. The supernatant of clone VI-235 in a radiolabelling assay only reacted with normal human livercells but on cryostatsections of human liver tissue no immunoreactivity was found. In the radiolabelled antiglobulin assay the supernatant of 7 clones reacted only with PLC/PRF/5 cells. Two of these, VI-133 and VI-196 showed a membrane immunofluorescence with PLC/PRF/5 cells (Fig. 7). On cryostatsections of human liver VI-133 showed an immunofluorescence staining pattern coinciding with bilecanaliculi (Fig. 8). In the radiolabelled antiglobulin assay only the supernatant of clone VI-196 exclusively reacted with PLC/PRF/5 cells. This supernatant was further tested by immunofluorescence and immunoperoxidase on cryostatsections of normal liver, HBsAg negative hepatocellular carcinoma and PLC/PRF/5 tumour grown in a nude mouse. On tissue sections, however, this clone did not show any immunoreactivity. 


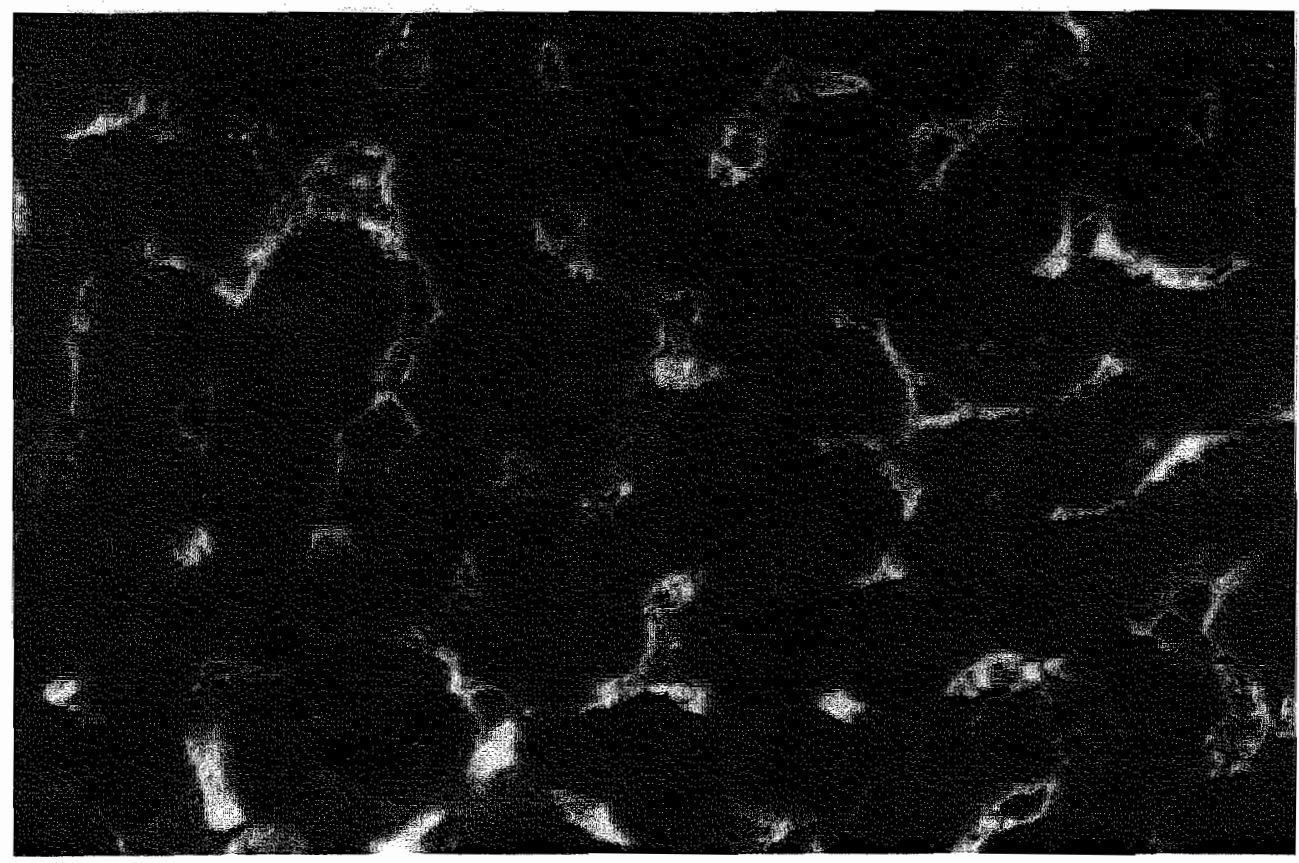

Figure 6. Normal liver cryostatsection incubated with McAb V1-44 and stained with fluorescein conjugated anti-mouse immunoglobulins.

Note: sinusoidal staining pattern.

Figure 7. PLC/PRF/5 cell incubated with McAb VI-196 and stained with fluorescein labelled antil-mouseimmunoglobulins.

Note: Linear to microgranular surface membrane staining pattern. 


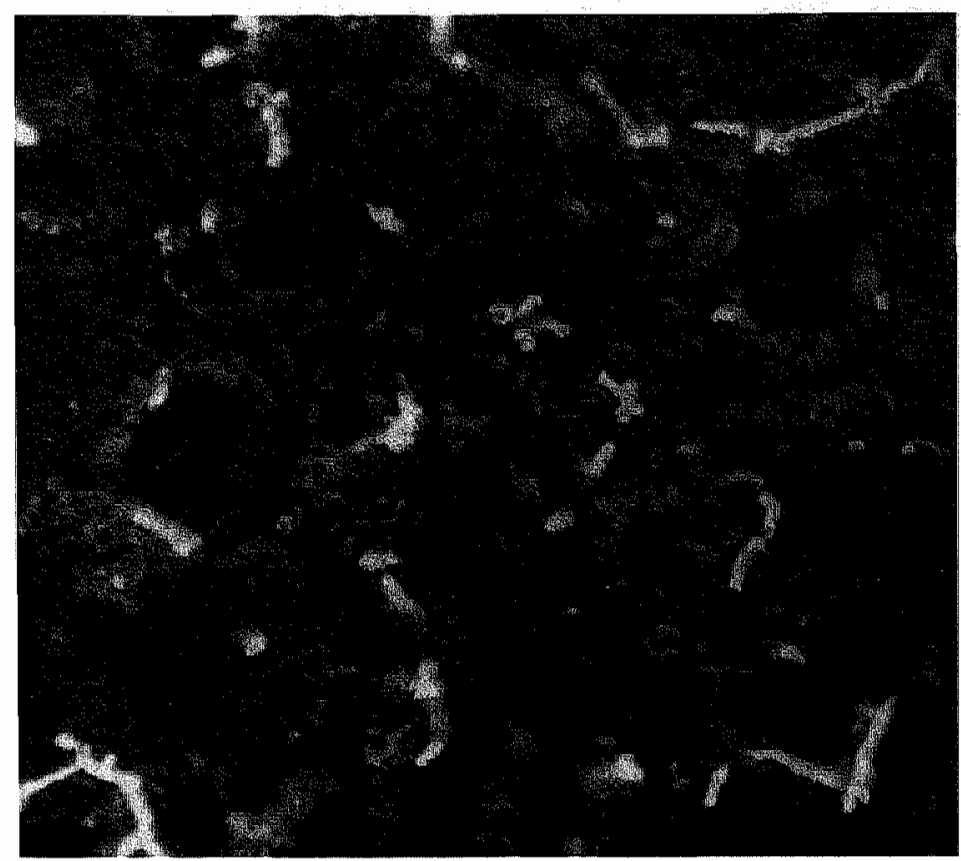

Figure 8. Normal liver cryostatsection incubated with McAb VI-133 and stained with rhodamin labelled anti-mouse immunoglobulins.

Note: bilecanalicular staining pattern.

\subsection{Discussion}

The search for tumour specific antigens on neoplastic cells has been a major goal in cancer research. Whether or not tumour specific antigens do exist is still a matter of debate. Only circumstantial evidence for the existence of tumour specific antigens in human tumour cells has been produced (Lennox, 1982).

With regard to hepatocellular carcinoma, Baldwin (1967) has shown that carcinogen induced hepatoma in the rat elicits a tumour specific immune response, suggesting that in this model antigens specific for hepatoma cells do exist. Specific antigens on human hepatoma cells, however, have not been reported as yet.

Our attempts to raise a PLC/PRF/5 cell specific antibody, which might detect a hepatoma specific antigen, yielded equiwocal results. 'Masking' of normal antigens on PLC/PRF/5 cells did not result in an antibody with a more limited range of immunoreactivities. Lysis of injected cells evidently makes the whole range of cellular and membrane antigens accessible for induction of an immuneresponse. The obtained antiserum did not react with $\mathrm{HBc}$ antigen, which is in agreement with studies showing that in PLC/PRF/5 cells mature viral particles are not produced (Skelly, 1979; Gerber, 1981). The reactivity of our antiserum with normal hepatocytes, lymphocytes: 
and $\mathrm{HBs} \mathrm{Ag}$ could be almost completely removed by adsorption procedures. After this step, however, some cross reactivity with HLA-antigens remained, as was shown by partial reduction of the immunoreactivity on PLC/PRF/5 cells after preincubation with an anti-HLA common antigen antibody.

The reactivity of our antiserum with hepatic tissue from a patient with anti-HBe positive CAH can also be explained by cross reactivity with HLA antigens which have been shown to be more densily expressed on hepatocytes in this condition (Thomas, 1982).

After extensive adsorption procedures and preincubation of tissues and cells prior to immune incubation with the adsorbed antiserum, only weak immunoreactivity with $\mathrm{PLC} / \mathrm{PRF} / 5$ cells and slightly more intense reactivity with liver tissue from the case of $\mathrm{HBeAg}+\mathrm{CAH}$ remained. Testing of the antiserum on a variety of normal epithelia and on different types of carcinoma by the immunoperoxidase method on cryostatsections revealed that cytoplasmic reactivity existed with cytoplasmic components of urothelium, prostatic epithelial cells and with ovarian and colonic adenocarcinoma. These results illustrate the problems which have been repeatedly encountered by many investigators when trying to detect tumour specific antigens by immunological techniques: non-specificity even after extensive adsorption. At this point we decided to adopt the hybridoma methodology (Köhler and Milstein, 1975) for the production of monoclonal antibodies, which for some types of cancer has already yielded promising results (Schlom, 1980; Steplewsky, 1979).

After 6 fusions we obtained 27 hybridoma clones which produced monoclonal antibody reactive with PLC/PRF/ 5 cells in a radiolabelled antiglobulin assay. These antibodies were further tested on a variety of different cell types and antigens (Table 8). Only one monoclonal antibody reacted strongly with PLC/PRF/ 5 cells in the radiolabelled antiglobulin assay as well as in immunofluorescence testing, but did not react with any other cell type or antigen. More specifically, this antibody did not react with normal rat or human hepatocytes nor with alpha-fetoprotein or HBsAg, antigens which do occur on PLC/PRF/5 cells (Thung, 1979; de Koning, 1984). Unfortunately, testing of this antibody on cryostatsections of a solid PLC/PRF/5 tumour, grown in a nude mouse, did not yield specific immunoreactivity. This finding implies that the VI 196 associated antigen can only be detected on intact cells in suspension. In line with this assumption we could not detect immunoreactivity of this antibody on cryostatsections of normal human liver and human hepatocellular carcinoma tissues. An alternative explanation may be that acetone or ethanol fixation interferes with the immunoreactivity of the antigens.

Among the library of obtained monoclonal antibodies two others were investigated. Our antibody VI-235 reacted in addition to PLC/PRF/ 5 cells exclusively with human hepatocytes. This may be an antibody directed against an organ specific antigen, as has previously been described by Meyer zum Büschenfelde (1979). Another monoclonal antibody (VI-191) reacted exclusively with HBsAg, which reemphasized the expression of HB viral antigens by PLC/PRF/5 cells (de Koning, 1984). 
Taken together the results of the specificity tests on antibody VI-196 suggest that this antibody may detect an epitope with a very limited distribution, including PLC/ PRF/5 cells. Testing of this antibody on a wide range of tissues will be necessary to confirm its specificity for an antigen associated with hepatocellular carcinoma. A complication in this context is the finding that the antibody did not react with cryostatsections. Although our attempts to generate hepatocellular carcinoma specific antibodies have not been entirely successful, recent work by Wiedmann (1983) leaves room for some optimism. This group reported the generation of several PLC/PRF/5 cell specific monoclonal antibodies. As always, however, much additional testing will have to be done before specificity claims in this area can be regarded as valid. Monoclonal antibodies specific for hepatocellular carcinoma would open up new possibilities in the diagnosis and therapy of this aggressive neoplasm. The PLC/PRF/ 5 cell tumour in the nude mouse may serve as an excellent model to test the potentialities of new monoclonal antibodies. This model has allowed the study of the effects of interferon (Bassendine, 1982) and ricin conjugated anti-HBsAg monoclonal antibody (Oladapo, 1982) on PLC/PRF/5 tumours. Factors complicating immunodiagnosis and immunotherapy, such as modulations of the expression of antigens by tumour cells (Ritz, 1981) and the occurrence of circulating antigens which block the binding of monoclonal antibodies to tumour cells (Nadler, 1980; Steplewski, 1981), may also be studied in this model.

In conclusion, we have shown that it is feasible to produce monoclonal antibodies which react with hepatocellular carcinoma cells and not with a variety of other cell types or antigens. Although these results do not justify a claim of tumour specificity and therefore do not provide additional clues with regard to the reality of the existence of tumour specific antigens, they warrant further research efforts in this intriguing area. 


\subsection{REFERENCES}

1. Abelew, G, J.

Production of embryonal serum alpha-globulin by hepatomas: Review of experimental and clinical data.

Cancer Res.: 28: 1344-1350, 1968.

2. Alexander, I.J., Bey, E.M., Geddes, E.W., Lecatsas, G.

Establishment of a continuously growing cell line from primary carcinoma of the liver.

S.Afr.Med.J." 50: 2124-2128, 1976.

3. Baldwin, R.W., Barker, C.R.

Demonstration of tumour-specific humoral antibody against amino-azo dye-induced rat hepatoma.

Brit.J Cancer; $21: 793-800,1967$.

4. Baldwin, J.W., Embleton, M.J., Moore, M.

Immunogenicity of rat hepatoma membrane fractions.

Brit.J.Cancer; 28: 389-399, 1973.

5. Barnstable, C.J., Bodner, W.F., Brown, G., Galfre, G., Milstein, C., Williams, A.F., Ziegler, A. Production of monoclonal antibodies group A erythrocytes HLA and other human cell surface antigens - New looks for genetic analysis.

Cell; 14: 9-20, 1978.

6. Bassendine, M.F., Oladapo, J.M., Koning, R.W. de, Palmar, J., Thomas, H.C., Sherlock, S. Interferon therapy in hepatocellular carcinoma: studies in an animal model.

Hepatology: 2: 164, 1982 .

7. Bloom, H.J., Richardson, N.W., Field, J.R.

Host resistence and survival in carcinoma of the breast - A study of 104 cases of medullary carcinoma in a series of 1411 cases of breast-cancer followed for 20 years.

Brit.Med.J.; 2: 181-184, 1970.

8. Burnet, F.M.

Immunological surveillance.

Pergamon Press, Sydney, 1970.

9. Chang, R.S.

Hela marker chromosomes, Chang liver cells and liver-specific functions.

Science; 199: $567,1978$.

10. Chism, S.E., Burton, R.C., Warner, N.L.

Immunogenicity of oncofetal antigens: a review.

Clin.llmmunol.Immunopath; 11: 346-373, 1978.

11. Colcher, D., Hand, P.H., Nuti, M., Schlom, J.

A spectrum of monoclonal antibodies reactive with human mammary tumor cells.

Proc.Natl.Acad.Sci.USA; 78: 3199-3203, 1981.

12. Deng, C., Terasaki, P.I., El-Awar, N., Bibling, R., Circiarelli, J., Lagasse, L.

Cytotoxic monoclonal antibody to a human leiomyosarcoma.

The Lancet; 1: 403-405, 1981.

13. Everson, T.C., Colle, W.H.

Spontaneous regression of cancer.

Saunders, Philadelphia, 1966.

14. Galfe, $\mathrm{O}_{n}$, Milstein, $C_{\text {., }}$, Wright, $B$.

Rat $x$ Rat hybrid myelomas and a monoclonal anti-Fd portion of mouse IgG.

Nature; 277: 131-133, 1979.

15. Gerber, M.A., Garfinkel, E., Hirschman, S.Z., Thung, S.N., Panagiotatos, T.

Immune and enzyme histochemical studies of a human hepatocellular carcinoma cell line producing hepatitis B surface antigen.

J.Immunol; 126" 1085-1089, 1981.

16. Hopf, U., Meyer zum Büschenfelde, K.H., Freudenberg, $\mathrm{J}$.

Liver specific antigens of different species. II. Localization of a membrane antigen at the cell surface of isolated hepatocytes.

Clin.Exp.Immunol.; 16:117-124, 1974. 
17. Hütteroth, T.H., Meyer zum Büschenfelde; K.H.

Antigenic relationship between Chang liver cells and human hepatocytes.

Klin. Wochenschr.; 56: 525-527, 1978.

18. Kaighn, M.E., Prince, A.M.

Production of albumin and other serum proteins by clonal cultures of normal hwman liver.

Proc.Natl.Acad Sci. USA; 68: 2396-2400, 1971.

19. Kawanishi, H., MacDermott, R.P.

K-cell-mediated antibody-dependent cellular cytotoxicity in chronic active liver disease.

Gastroenterology; 76: 1: 151-158, 1979.

20. Kennett, R.H., Gilbert, F.

Hybrid myelomas producing antibodies against a human neuroblastoma antigen present on fetal brain.

Science; 203: 1120-1122, 1979.

21. Klein, E., Klein, G., Nadkarin, J.S.

Surface IgM-kappa specificity on a Burkitt lymphoma cell in wivo and derived cultured lines.

Cancer Res.; 28: 1300-1313, 1968.

22. Klein, P.A.

Problems with and approaches to specificity in the serologic measurement of histoconpatibility and tumour-associated antigens on tumor cell surfaces.

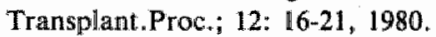

23. Köhler, G., Milstein, C.

Continuous cultures of fused cells secreting antibody of predefined specificity.

Nature; 256: 495-497, 1975.

24. Koning, R.W. de, Goodall, A., Varghese, Z., Thomas, H.C.

Hepatitis B virus and host cell membrane antigens on a primary hepatocellular carcinoma cell line.

Liver; 4: 1-6, 1984.

25. Koprowski, H., Steplewski, Z, Herlyn, D., Herlyn, M.

Study of antibodies against human melanoma produced by somatic cell hybrids.

Proc.Natt.Acad.Sci.USA; 75: 3405-3409, 1978.

26. Ledbetter, J., Nowinski, R.C.

Identification of the Gross cell surface antigen associated with murine leukemia virus-infected cells.

I. Virol; 23: 315-322, 1977.

27. Lennox, E.S., Sikora, K.

Definition of human tumor antigens.

In.: Monoclonal Antibodies in Clinical Medicine.

Eds.: McMichael, A.J. and Fabre, J.W.

Academic Press, 1982.

28. McGee, J.O.D., Woods, J.C., Askall, F., Bramwell, M.E., Harris, H.

A new marker for human cancer cells. 2. Immunohistochemical detection of the Ca antigen in human tissues with the Cal antibody.

The Lancet; 2: 7-11, 1982.

29. Meyer zum Büschenfelde, K.H., Hütteroth, T.H., Arnold, W., Hopf, U.

Immunologic liver injury: the role of hepatitis B viral antigens and liver membrane antigens as targets.

In: Progress in Liver Diseases; VI: 407-424.

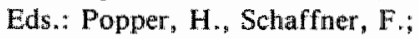

Grune and Stratton, New York, 1979.

30. Moller, E.

Isoantigenic properties of tumors transgressing histocompatibility barriers of the H-2 system.

J.Natl.Cancer Inst.; 33: 979-989, 1964.

31. Morris, R.J., Williams, A.F.

Antigens on mouse and rat lymphocytes recognized by rabbit antiserum against rat brain: the quantitative analysis of a xenogeneic antiserum.

Eur.J.Immunol: 5: 274-281, 1975.

32. Nadler, L.M., Stashenko, Ph, Hardy, R., Kaplan, W.D., Button, L.N., Kufe, D.W., Antman, K.H., Schlossman, S.F. 
Serotherapy of patient with a monoclonal antibody detected against a human Iymphoma-associated antigen.

Cancer Res.; 40: 3147-3154, 1980.

33. Nelson-Rees, W.A., Flandermeyer, R.R.

Hela cultures defined.

Science; 191: 96-98, 1976.

34. Oladapo, J.M., Goodall, A.H., Parmar, J., Koning, R.W. de, Brown, D., Thomas, H.C.

In vitro and in vivo cytotoxic activity of native and ricin conjugated monoclonal antibodies to HBs antigen for Alexander primary liver cell carcinoma and tumours.

Gut; 25: 619-623, 1984.

35. Pallesen, G., Jepsen, F.L., Hastrup, J., Ipsen, A., Hvidberg, N.

Experience with the Oxford tumour marker (Cal) in serous fluids.

The Lancet; 1: 1326, 1983.

36. Pearson, $T$., Sikora, $K$, Lennox, E.

Measurement of $\mathrm{H}_{2}$ antigen and immunogenicity of methylcholanthrene-induced murine sarcomas.

Brit.J,Cancer: 37: $530-535,1978$.

37. Pretr, R.T., Main, J.M.

Immunity to methylcholanthrene induced sarcomas.

J.Natl.Cancer Inst.; 18: 769-778, 1957.

38. Pulfertaft, R, J.

Cytology of Burkitt's tumour (African lymphoma).

The Lancet; 1: 238-240, 1964.

39. Ritz, J., Pesano, J.M., Sallan, S.E., Clavell, L.A., Notis-McConarty, J., Rosenthal, P., Schlossman, S.F.

Serotherapy of acute lymphoblastic leukemia with monoclonal antibody.

Blood; 58: 141-152, 1981 .

40. Schlom, J., Wunderlich, D., Teramoto, Y.O.

Generation of human monoclonal antibodies reactive with human mammary carcinoma cells.

Proc.Natl .Acad.Sci. USA; 77: 6841-6845, 1980.

41. Simpson, H.W., Candlish, W., Liddle, C., McGregor, F.M., Mutch, F., Tinkler, B.

Experience of the Oxford tumour marker.

The Lancet; 1: 1097, 1983.

42. Skelly, J., Copeland, J.A., Howard, C.R., Zuckerman, A.J.

Hepatitis $B$ surface antigen produced by a human hepatoma cell line.

Nature; 182: 617-618, 1979.

43. Steplewski, Z., Herlyn., M., Herlyn, D., Clark, W.H., Koprowski, H.

Reactivity of monoclonal anti-melanoma antibodies with melanoma cells freshly isolated from primary and metastatic carcinoma.

Eur.J.Immunol.; 9: 94, 96, 1979.

44. Steplewski, Z, Chang, T.H., Herlyn, M. Koprowski, H.

Release of monoclonal antibody-defined antigens by human colorectal carcinoma and melanoma cells.

Cancer Res.; 41: 2723-2727, 1981.

45. Thomas, H.C., Montano, L., Goodall, A., Koning, R.W. de, Oladapo, J., Wiedmann, K.H. Immunological mechanisms in chronic hepatitis $B$ wirus infection.

Hepatology; 2: 116S-121S, 1982.

46. Thung, S.N., Gerber, M.A., Sarno, E., Popper, H.

Distribution of five antigens in hepatocellular carcinoma.

Lab. Invest.; 41: 101-105, 1979.

47. Wiedmann, K.H., Trejdosiewicz, L.K., Thomas, H.C.

Identification of membrane antigens expressed on primary liver cancer (PLC) cells but not on normal untransformed hepatocytes (abstract).

Hepatology; 3: 865, 1983. 


\section{CHAPTER V}

\section{Liver membrane antibodies: studies on PLC/PRF/5 cells}

\subsection{IMMUNOFLUORESCENCE DETECTION OF LIVER CELL MEMBRANE ANTIBODIES USING PLC/PRF/5 CELLS*}

\subsubsection{Introduction}

An increasing body of evidence suggests that hepatocellular injury in acute and chronic hepatitis is mediated by immunological mechanisms. Using isolated rabbit hepatocytes as a test substrate, sera of patients with HBsAg negative chronic active hepatitis $(\mathrm{CAH})$ and other inflammatory liver diseases (Hopf, 1976; Tage-Jensen, 1977; Schuurman, 1982; Meliconi, 1983a) have been shown to contain antibodies reactive with livercell surface antigens. These have been called liver membrane autoantibodies (LMA). One of the involved antigenic determinants was shown to be a lipoprotein, which has been designated liver membrane antigen (LMAg) (Meyer zum Büschenfelde, 1979). It is not unlikely that in addition to LMAg other surface antigens are also detected in the LMA-test.

Several observations suggest that immunological mechanisms are important in the pathogenesis of several inflammatory liver diseases. Evidence in favor of the involvement of the humoral immune system was provided by Meyer zum Büschenfelde (1979), who demonstrated in vivo fixation of immunoglobulins to plasma membranes. of human hepatocytes in acute and chronic hepatitis and by Eggink (1984), who identified IgG plasmacells in liver-biopsies in patients with $\mathrm{CAH}$. The latter investigators also detected killer cells in these liverbiopsies, supportive of a role of cellular immunity.

Liver cell membrane antibodies in patient sera are usually detected by an immunofluorescence assay on isolated rabbit hepatocytes (Hopf, 1976; Schuurman, 1982). In this technique only species cross-reactive antibodies against liver cell surface membrane antigens will be detected. From a theoretical point of view human hepatocytes would be preferable, but their availability is obviously limited and preparation of viable cell suspensions from liver biopsies is rather complicated. Earlier studies (Chisari, 1981; Lebwohl, 1981; de Koning, 1984) of the highly differentiated PLC/PRF/5 human hepatoma cell line (Alexander, 1976) showed that these cells share many characteristics with normal human hepatocytes such as membrane antigens, enzyme systems and production of serum proteins (Dodd, 1978; Gerber, 1981; Tabor, 1981; Alexander, 1982). We therefore developed an assay for the detection of liver membrane antibodies on PLC/PRF/ 5 cells and compared the results with those obtained using rab-

* In press: Koning, R.W. de, Daemen, M. , Schutte, B., Geertzen, H.G.M., Blijham, G.H., Bosman, F.T; Eur.J.Clin.Invest. 
bit hepatocytes as substrate. In addition we used flowcytometric analysis of immuneincubated PLC/PRF/5 cells as a more objective method allowing quantitation of the results of the test (Melamed, 1979; Blijham, 1983).

\subsubsection{Materials and methods}

\subsubsection{Sera.}

Serum samples of ten patients with chronic hepatitis were used as test samples. The cases were selected on the basis of absence of evidence of viral or hepatotoxic etiology. An LMA assay (Schuurman, 1982), using rabbit hepatocytes as substrate, was applied for the detection of liver specific autoantibodies. These assays were performed in the Central Laboratory of the Netherlands Red Cross Blood Transfusion Service (CLB, Amsterdam). The sera were subsequently coded and assayed again using PLC/PRF/ 5 cells as substrate. Ten normal human sera, derived from healthly colleagues, were used to assess the level of non-specific binding of human sera to $\mathrm{PLC} / \mathrm{PRF} / 5$.

\subsubsection{Cell lines}

PLC/PRF/5 cells (Alexander, 1976) were grown in Dulbecco's modification of Eagle's MEM (GIBCO) supplemented with $3.5 \mathrm{mg}$ per $\mathrm{ml}$ glucose, $0.2 \mathrm{mg}$ per $\mathrm{ml} \mathrm{l-}$ glutamine and $10 \%$ fetal calf serum at $37^{\circ} \mathrm{C}$ in a humidified $5 \% \mathrm{CO}_{2} 95 \%$ air incubator with a split ratio of $1: 4$. The cells were harvested by trypsinization. The specificity of the autoantibodies for PLC/PRF/5 cells was tested on cell lines of human breast and colonic carcinoma and on human fibroblasts. The breast cancer cells were derived from the well-known MCF-7 cancer cell line. The colonic carcinoma cell line (7355-83) was developed in our laboratory. The fibroblasts were derived from a primary culture of human skin (1112-84). All cultures were maintained as described above for the PLC/PRF/ 5 cells. The cells were used for fluorescence testing within 1 hour after harvesting. The viability of the cells was always better than $90 \%$ as determined with the trypan blue exclusion test.

\subsubsection{Immunofluorescence test.}

After washing with phosphate buffered saline (PBS, $2 \times 5$ min.) $50 \mu \mathrm{l}$ of cell suspension (containing $10^{6}$ cells) was incubated with $5 \mu$ l of testserum $\left(30 \mathrm{~min} ., 0^{\circ} \mathrm{C}\right.$ ). After washing with PBS containing $0.1 \%$ bovine serum albumin and $0.01 \%$ sodium azide (PBSA) the cells were pelleted and incubated with $5 \mu$ fluorescein conjugated $\mathrm{F}(\mathrm{ab})_{2}$ fragment goat anti-human immunoglobulins $(\operatorname{IgA}+\operatorname{IgG}+\operatorname{IgM}$ ) (Cappel Laboratories, Cochranville, USA, lot 16979 ) for 30 minutes at $0^{\circ} \mathrm{C}$. After washing the cells were mounted on slides and visually read using a Zeiss fluorescence microscope with 
epi-illuminator. Three observers read the slides independently, assigning a score (negative, weakly positive or positive) to each sample. Interobserver agreement was complete.

\subsubsection{Flowcytometry.}

Samples were analysed on a FACS IV cell sorter (Becton and Dickinson, Sunnyvale CA) equipped with a 2 W Argon ion laser (Spectra Physics, 164-01), operating at 488 nm. Gates were set on forward and right angle light scatter to exclude dead cells and cell clumps. Fluorescence histograms of 2500 cells were recorded on a logarithmic scale (40 channels being one decade).

Control samples were stained with normal human sera (first layer) followed by fluorescein conjugated $F(a b)_{2}$ goat anti-human immunoglobulins.

Background levels of immunofluorescence were determined by incubating PLC/ PRF/5 cells with sera of 10 normal healthy volunteers. The relative fluorescence intensity (RFI) was calculated according to the equation: $R F I=10^{x}$, where $x$ is:

PFC* (sample)-PFC(control)

40

The mean RFI for the control sera was $1,1 \pm 0.4$, so that a sample was considered positive when exceeding the $95 \%$ confidence level of 1.9 .

Since the number of positively stained PLC/PRF/5 cells for the control sera varied with the quality of cells from batch to batch, this was not considered as a reliable indicator of immunoreactivity especially in weakly positive sera.

\subsubsection{Results}

In all positive sera membrane fluorescence of isolated rabbit hepatocytes was observed with occasionally branching linear aggregates (Fig.1). Four testsera were negative, 5 positive (Fig.1.) and one weakly positive (Table 1) using the established rabbit hepatocyte assay for detection of liver membrane reactive antibodies. Using PLC/PRF/ 5 cells, two of the sera which were scored positive on rabbit hepatocytes, were weakly positive and one serum, weakly positive on rabbit hepatocytes, turned out to be negative on PLC/PRF/5 cells. The membrane fluorescence pattern of a PLC/PRF/5 cell is shown in Fig.2. All 10 normal human sera scored negative. A typical flowcytometric reading, consisting of a fluorescence histogram of 2500 cells recorded on a logarithmic fluorescence intensity scale, is shown in Figure 3. Flowcytometric results, expressed as the relative fluorescence intensity, are given in Table 2 . The correlation between visual and flowcytometric reading was found to be excellent. When a relative fluorescence intensity in excess of 1.9 was considered as positive, all

* PFC $=$ Peak Fluorescence Channel. 


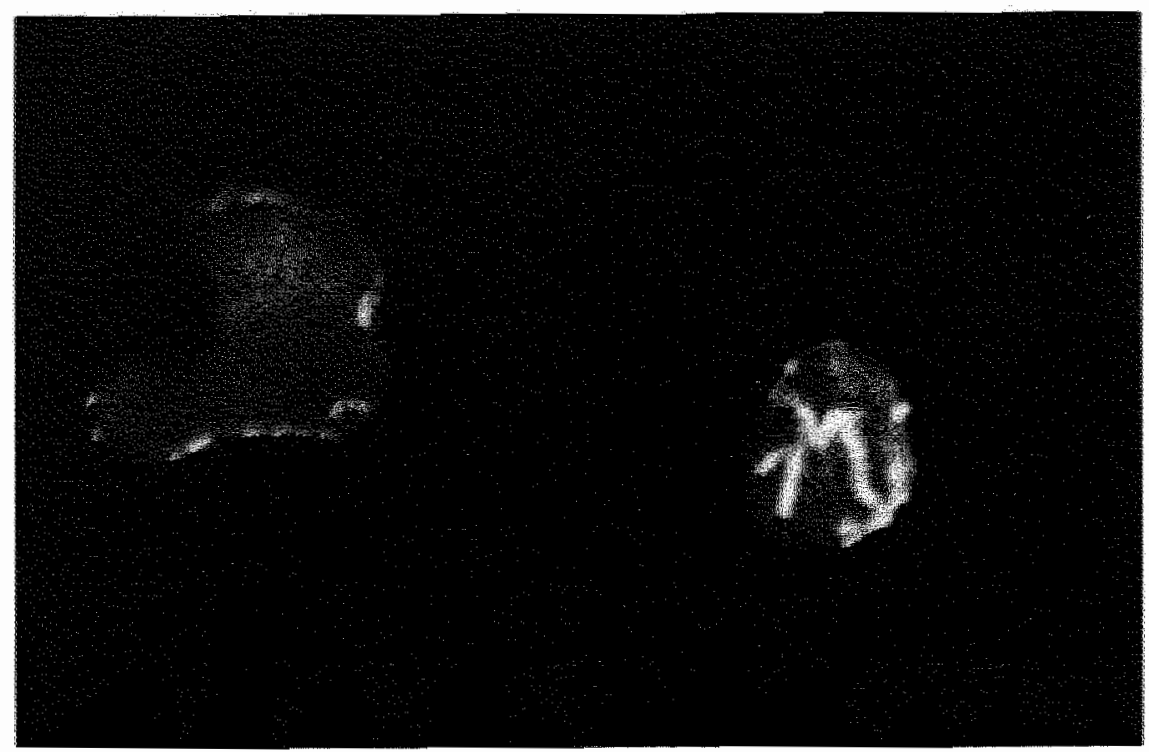

Figure 1: Rabbit liver cells incubated with a positive serum and stained with fluorescein conjugated antihuman immunoglobulins.

Note: bright surface mambrane staining patten with occasionally branching linear aggregates.
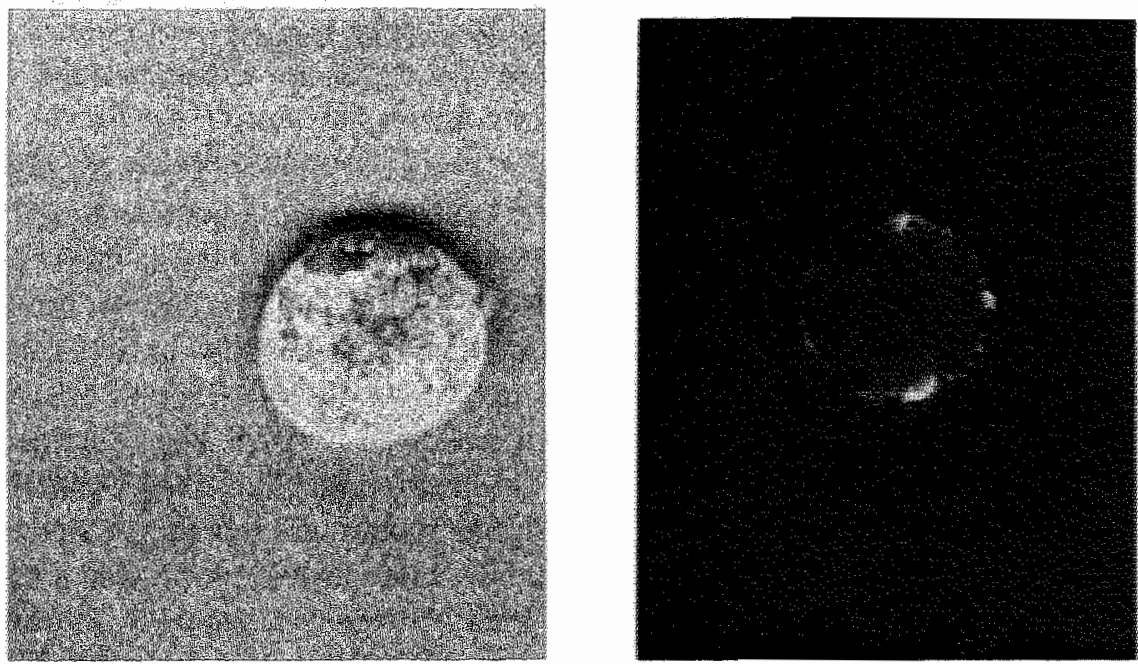

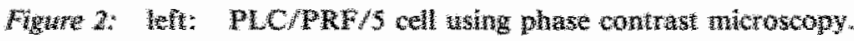

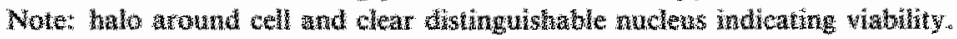

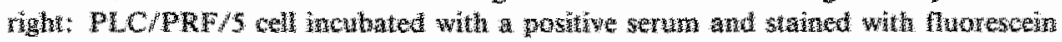

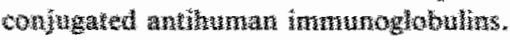

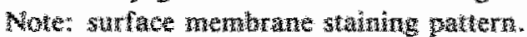




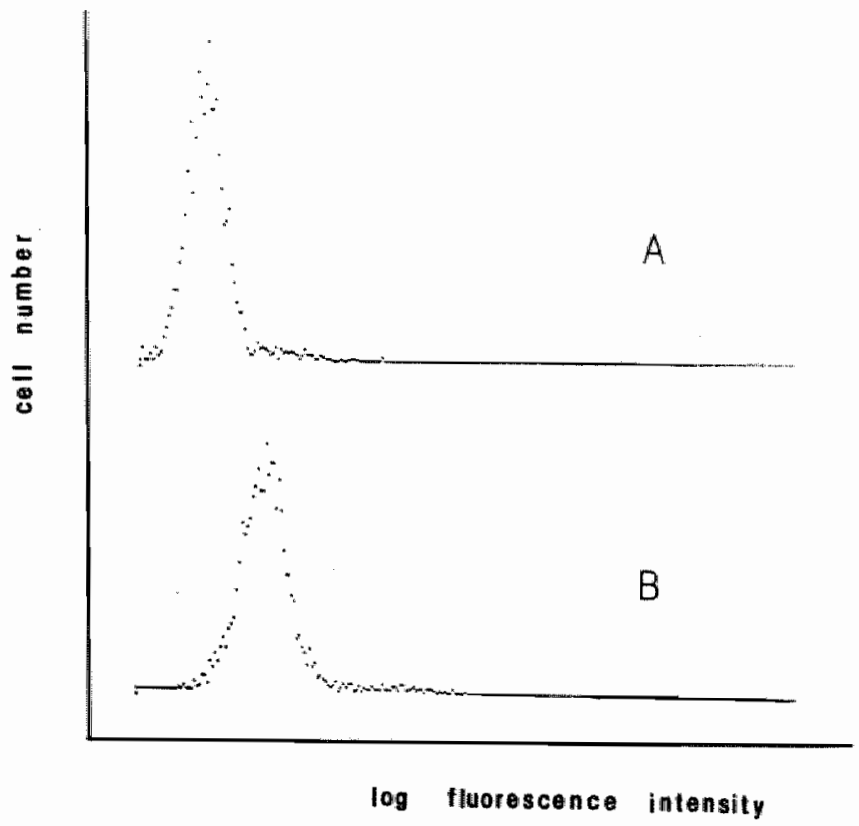

Figure 3: Membrane fluorescence distribution of PLC/PRF/5 cells stained with control serum (A) and test serum (from patient no 7) (B).

Note: the shift towards higher fluorescence intensity of the thest serum.

sera, scored negative on visual reading, were found to be negative ( $0 \%$ false positive) and all positive and weakly positive sera were found to be positive $(0 \%$ false negative). All normal human sera showed a relative fluorescence intensity of less than 1.9 .

In order to assess the hepatocellular specificity of the detected antibodies additional tests were performed on human cell lines of non-hepatocellular origin. Two strongly positive testsera ( 2 and 7 ) and two negative testsera ( 8 and 9) were tested on MCF-7, 7355-83 and fibroblast culture cells. In none of these tests was membrane fluorescence observed by visual reading (Table 3). Flowcytometric analysis confirmed these results: all relative fluorescence intensity values were below 1.9.

\subsubsection{Discussion}

Hopf (1976) was the first to observe that immunoglobulins from some patients with HBsAg negative chronic active hepatitis reacted with the plasma membrane of isolated rabbit hepatocytes in an indirect immunofluorescence test. Based on this observation a routine assay was developed for the detection of liver membrane antibodies (Schuurman, 1982; Meliconi, 1983). In this test only species cross-reactive antibodies against liver cell surface membrane antigens, including LMAg, can be assayed. Species specific liver membrane antibodies, however, cannot be detected in this assay. 
These can only be detected using human hepatocytes as the test substrate. Normal human hepatocytes, however, are an impractical substrate for routine use because of their poor availability.

Earlier studies (Chisari, 1981; Lebwohl, 1981; de Koning, 1984) showed that many antigens on normal human hepatocytes also occur on cells derived from a well differentiated human hepatoma (PLC/PRF/5) (Alexander, 1976). These results suggest that PLC/PRF/5 cells might be an alternative suitable substrate for the detection of liver membrane antibodies. The present study establishes the suitability of these cells as a substrate for the detection of liver membrane antibodies. The minor discrepancies, which in our study were found to exist between the results on rabbit hepatocytes and those on PLC/PRF/ 5 cells (PLC/PRF/5 cells usually showing less fluorescence), may be a result of trypsinization of these cells during harvesting. We are currently exploring whether mechanical harvesting of the cells or reconstruction of membrane antigens by brief culturing of the cells in suspension after harvesting, may improve the agreement. "The liver cell specificity of $\mathrm{PLC} / \mathrm{PRF} / 5$ reactive antibodies was confirmed by the absence of reactivity of PLC/PRF/5 positive sera on cells derived from human breast cancer cells, colonic cancer cells and fibroblasts.

We finally explored the possibilities for quantification of the assay by applying flowcytometry. Complete agreement was found between visual reading and flowcytometric analysis using the relative fluorescence intensity. Our data indicate that the flow-

Table I: Microscopical (visual) evaluation of rabbit hepatocytes and PLC/PRF/5 cells as substrates in an immunofluorescence assay for detection of liver membrane antibodies.

Cell suspension

Rabbit liver

PLC/PRF/5

Test serum $\begin{array}{rrr}1 & ++ & ++ \\ 2 & ++ & ++ \\ 3 & ++ & + \\ 4 & ++ & + \\ 5 & - & + \\ 6 & ++ & + \\ 7 & - & - \\ 8 & - & - \\ 9 & - & - \\ 10 & & +\end{array}$

Legends:

++ positive : bright membrane fluorescence

$+\quad$ weakly positive : weak membrane fluorescence

- negative : no membrane fluorescence. 
Table 2: Microscopic (visual) and flowcytometric analysis of normal and patient sera in an immunofluorescence assay on PLC/PRF/5 cells for detection of liver membrane antibodies.

\begin{tabular}{rcccc}
\hline & \multicolumn{2}{c}{ normal human sera } & \multicolumn{2}{c}{ patient sera } \\
sera & visual reading & RFI & visual reading & RFI \\
\hline 1 & - & 0.8 & ++ & 2.0 \\
2 & - & 1.0 & ++ & 6.3 \\
3 & - & 1.1 & - & 1.8 \\
4 & - & 0.7 & + & 2.7 \\
5 & - & 1.5 & - & 2.0 \\
6 & - & 0.9 & ++ & 1.4 \\
7 & - & 0.6 & - & 3.8 \\
8 & - & 1.2 & - & 1.2 \\
9 & - & 1.5 & - & 1.2 \\
10 & - & 1.2 & & 0.6 \\
\hline
\end{tabular}

Legends:

+ positive : bright membrane fluorescence

+ weakly positive : weak membrane fluorescence

- negative : no membrane fluorescence

Table 3: Microscopic and flowcytometric analysis of 2 LMA positive patient sera (2 and 7) and 2 LMA negative patient sera ( 8 and 9) on breast cancer cells (MCF-7), colonic cancer cells (7355-83) and human fibroblasts (1112-84)

\begin{tabular}{lcccccc}
\hline & & \multicolumn{2}{c}{ MCF-7 } & \multicolumn{2}{c}{$7355-83$} & \multicolumn{2}{c}{$1122-84$} \\
sera & visual reading & RFI & visual reading & RFI & visual reading & RFI \\
\hline 2 & - & 1.4 & - & 0.7 & - & 1.1 \\
7 & - & 1.2 & - & 0.9 & - & 0.8 \\
8 & - & 1.1 & - & 1.2 & - & 0.9 \\
9 & - & 0.9 & - & 0.8 & - & 1.1 \\
\hline
\end{tabular}

cytometrically determined relative fluorescence intensity is a reliable parameter to distinguish between positive and negative sera.

Based on these findings we conclude that PLC/PRF/ 5 cells may be a highlly suitable substrate for the detection of liver membrane antibodies. In addition, we feel that flowcytometric analysis is a useful method for objectivation and quantification of immunofluorescence analysis of liver membrane antibodies.

Further studies are necessary to evaluate the validity of PLC/PRF/5 cells as substrate for liver membrane antibodies. These studies may provide answers to questions regarding the nature of the involved membrane antigens and whether or not species-specific antibodies exist. 


\subsubsection{Summary}

Detection of liver membrane antibodies is routinely performed by immunofluorescence testing of patient sera on rabbit hepatocyte suspensions. We have investigated the possible use of cells from the PLC/PRF/5 human hepatoma cell-line. These cells were employed as substrate in an immunofluorescence test which was compared with the conventional rabbit hepatocyte assay. We found a close correlation between the results obtained with these different substrates on visual reading. We furthermore compared visual reading of immunofluorescence preparations with flowcytometric analysis of immunostained cell suspensions. The resuits with these different methods were largely confirmatory. The PLC/PRF/5 cells are easily available and should therefore be regarded as a highly valuable new substrate for detection of liver membrane antibodies. Flowcytometry appears to be a technically simple and reliable method for quantitative analysis. 


\subsubsection{REFERENCES}

1. Alexander, J.J., Bey, E.M., Geddes, E.W., Lecatsas, G.

Establishment of a continuously growing cell line from primary carcinoma of the liver.

S.Afr.Med.J.; 50: 2124-2128, 1976.

2. Alexander, J.J., Merwe, Ch.F. van der, Saunders, R.M., McElligott, S.E., Desmyter, J

A comparison between in vitro experiments with a hepatoma cell line and in vivo studies.

Hepatology; 2: 92s-96s, 1982.

3. Blijham, G.H., Schutte, B.

Flowcytometry in oncoloy: a review with emphasis on DNA flowcytometry in human solid tumors. Neth.J.Med.; 26: 314-320, 1983.

4. Chisari, F.V., Bieber, M.S., Josepho, C.A., Xavier, C., Anderson, D.S.

Functional properties of lymphocyte subpopulations in hepatitis B virus infection.

II. Cytotoxic effector cell killing of targets that naturally express hepatitis $B$ surface antigen and لliwer-specific lipoprotein.

J.Imnunol.; 26: 45-49, 1981.

5. Dodd, R., Gouaux, T., Bastiaans, $M$.

Biosynthesis of HBsAg and serum proteins by a human hepatoma cell line.

In.: Viral Hepatitis, 698-709.

Eds.: Vyas, G., Cohen, S., Schmidt, R.

Franklin Institute Press, Philadelphia, 1978.

6. Eggink, H.F.

Liver membrane autoantibodies and the pathogenesis of liver diseases.

In: Cellular and humoral immune reactions in liver diseases.

Thesis, State University Groningen, 1984.

7. Gerber, M., Garfinkel, E., Hirschman, S.Z., Thung, S.N., Panagiotatos, T.

Immune and enzyme histochemical studies of a human hepatocellular carcinoma celline producing hepatitis B surface antigen.

J.Immunol.; 126: 1085-1089, 1981.

8. Hopf, U., Meyer zum Büschenfelde, K.H., Arnold, W.

Detection of a liver-membrane autoantibody in HBsAg negative chronic active hepatitis.

N.Engl.J.Med.; 294: 578-582, 1976.

9. Koning, R.W. de, Goodall, A., Varghese, A., Thomas, H.C.

Hepatitis $B$ virus and host cell membrane antigens on a primary hepatocelluiar carcinoma cell line.

Liver; 4: 1-6, 1984.

10. Lebwohl, N., Gerber, M.A.

Characterization and demonstration of human liver-specific protein (LSP) and apo LSP.

Clin.Exp.Immunol.; 46: 435-442, 1981.

11. Melamed, M.R., Mullaney, P.F., Mendelsohn, M.L.

Flowcytometry and sorting.

New York: John Wiley and Sons, 1979.

12. Meliconi, K., Stancari, M., Garagnani, M., Baraldini, M., Stefanini, G.F., Miglio, F., Gasbar* rini, $\mathbf{G}$.

Occurrence and significance of IgG liver membrane autoantibodies (LMA) in chronic liver diseases. of different aetiology.

Clin.Exp.Immunoll, 51: 565-571, 1983a.

13. Meliconi, R., Miglio, F., Stancari, M., Baraldini, M., Stefanini, G., Gasbarrini, G.

Hepatocyte membrane-bound IgG and circulating liver-specific autoantibodies in chronic liwer disease: relation to hepatitis B virus serum markers and liver histology.

Hepatology; 3: 155-161, 1983b.

14. Meyer zum Büschenfelde, K.H., Hütteroth, T.H., Arnold, W., Hopf, U.

Immunologic Liver injury: the role of hepatitis B viral antigens and liver membrane antigens as targets.

In: Progress in Liver Diseases; VI: 407-424.

Eds.: Popper, H., Schaffner, F.

Grune and Sitratton, 1979. 
15. Schuurman, H.J., Vogten, A.J.M., Schalm, S.W., Fevery, J. Clinical evaluation of the liver cell membrane autoantibody assay. Digestion; 23: 184-193, 1982 .

16. Tabor, E., Copeland, J.A., Mann, G.F., Howard, C.R., Skelly, J., Snoy, P., Zuckerman, A.J., Gerety, R.J.

Nondetection of infectious hepatitis B virus in a human hepatoma cell line producing hepatitis B surface antigen.

Intervirology: 15: 82-86, 1981.

17. Tage-Jensen, U., Amold, W., Dietrichson, O., Hardt, F., Hopf, U., Meyer zum Büschenfelde, K.H., Nielsen, J.O.

Liver cell membrane autoantibody specific for ünflammatory liver diseases.

Brit.Med.J.; 1. 206-208, 1977. 


\subsection{HUMAN HEPATOMA CELL REACTIVE ANTIBODIES IN INFLAMMA- TORY LIVER DISEASE: A STUDY ON PLC/PRF/5 CELLS*}

\subsubsection{Introduction}

Many studies have indicated that the immune system plays an important role in the pathogenesis of inflammatory liver disease (Hopf, 1974; Cochrane, 1976; Meyer zum Büschenfelde, 1979a). The presence of IgG fixed to hepatocytes isolated from liverbiopsies of patients with chronic inflammatory liver diseases (Hopf, 1975), supported the hypothesis that circulating antibodies exist which react with membrane antigens in vivo. In a recent study a relationship between presence of membrane bound IgG and severity of portal inflammatory infiltration was established (Meliconi, 1983a). Eggink (1984) could not demonstrate a correlation between the presence or absence of liver membrane reactive antibodies in serum and the number and phenotype of potential effector cells in liverbiopsies in a follow-up study of autoimmune chronic active liver disease. Although the potential role for liver membrane reactive antibodies in the pathogenesis of CALD has not been clarified, these antibodies appear to be important diagnostic markers (Schuurman, 1982; Wiedmann, 1984). Hopf (1976) was the first to detect liver membrane antibodies (LMA) in an indirect immunofluorescence assay on suspensions of rabbit hepatocytes. In such an assay only species cross-reactive antibodies can be detected. In order to detect antibodies against species-specific antigens it is necessary to perform the test on human hepatocytes, but availability of these cells is obviously limited. In a pilot study (de Koning, in press) we found, that the well differentiated human hepatocellular carcinoma cell line PLC/PRF/5 (Alexander, 1976; de Koning, 1984) may be a valuable new substrate for detection of liver membrane antibodies. However, one has to take into account the presence of Hepatitis B surface antigen ( $\mathrm{HBs} \mathrm{Ag}$ ) on the membrane of this cell (de $\mathrm{Ko}-$ ning, 1984). In the present study we have tested serum samples of patients with several well defined inflammatory liver diseases for the presence of liver membrane antibodies by a conventional assay and for PLC/PRF/5 cell reactive antibodies. The Ausab test (Abbott Laboratories) was applied to exclude antibodies against Hepatitis $B$ surface antigen. The immunoglobulin class patterns were determined on sera which were positive in either the conventional or PLC/PRF/5 cell assay. In addition to visuall reading, flowcytometric analysis was employed as a more objective method allowing quantitation of the results (Blijham, 1983; de Koning, 1985).

\footnotetext{
* Submitted: Koning, R.W. de, Geertzen, H.G.M., Schutte, B., Verstijnen, C., Fevery, J.,
} Hattum, J. wan, Janssens, A.R., Bosman, F.T.; J. Hepatol. 


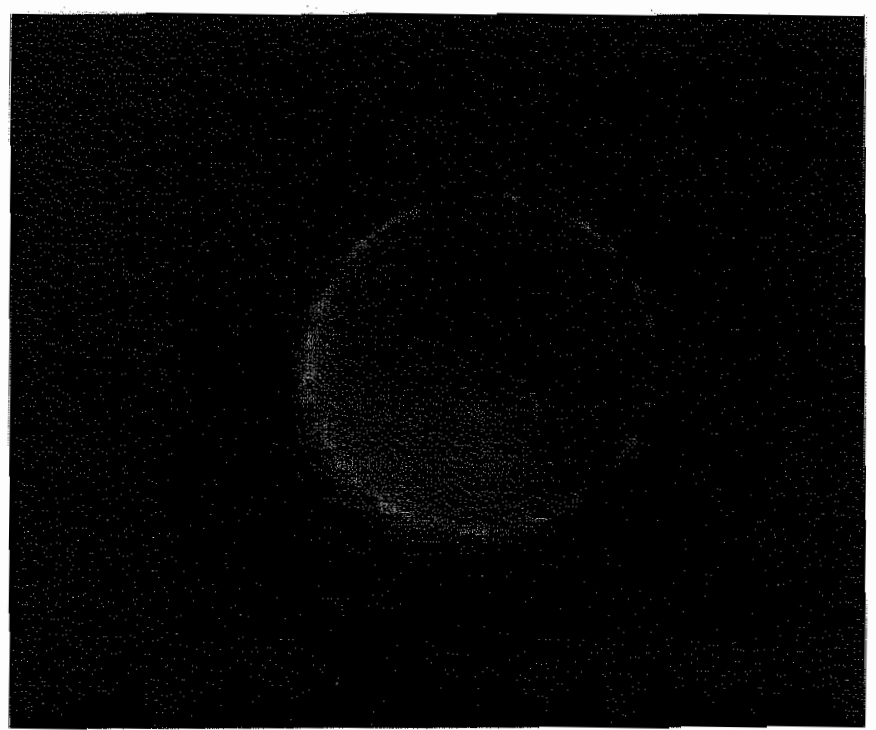

Figure 1: PLC/PRF/5 cell incubated with a positive serum (patient with sclerosing cholangitis) and stained with fluorescein conjugated anti-human $\mathbf{I g G}$.

Note: mixed microgranular and linear surface membrane staining pattern

\subsubsection{Materials and methods}

\subsubsection{Patient material}

Serum samples of 91 patients with well defined acute or chronic inflammatory liver diseases (Table 1) were used as test samples. The diagnoses had been confirmed by clinical analysis, serological tests and histological evaluation of liver biopsy specimens. A liver membrane antibody (LMA) assay using rabbit hepatocytes as substrate (Schuurnan, 1982), was employed for the detection of liver membrane antibodies. This assay was performed in the Central Laboratory of the Netherlands Red Cross Blood Transfusion Service (CLB, Amsterdam). The sera were subsequently coded and assayed again using PLC/PRF/5 cells as substrate. Sera positive with the $\mathrm{PLC} / \mathrm{PRF} / 5$ cell assay were tested for antibodies against hepatitis $\mathrm{B}$ surface antigen (HBsAg) with the Ausab test (Abbott Laboratories) performed by the Viral Hepatitis Laboratory of CLB. The sera of 10 healthy individuals were used as negative controls.

\subsubsection{PLC/PRF/5 cells}

Cells of the PLC/PRF/5 human hepatocellular carcinoma cell line (also known as the 
Alexander cell line) (Alexander, 1976) were cultured in Dulbecco"s modification of Eagle's MEM (GIBCO) supplemented with $3.5 \mathrm{mg}$ per $\mathrm{ml}$ glucose, $0.2 \mathrm{mg}$ per ml 1-glutamine and $10 \%$ fetal calf serum at $37^{\circ} \mathrm{C}$ in a humidified $5 \% \mathrm{CO}_{2} 95 \%$ air incubator with a split ratio 1:4. The cells were harvested by trypsinization. The viability of the cells was better than $90 \%$ as determined with the trypanblue exclusion test.

\subsubsection{Immunofluorescence test}

After washing ( $2 \times 5 \mathrm{~min}$.) with phosphate buffered saline (PBS) $50 \mu \mathrm{l}$ of cell suspension, diluted to contain $10^{6}$ cells, was incubated with $5 \mu \mathrm{l}$ of testserum ( $30 \mathrm{~min}$; $0^{\circ} \mathrm{C}$ ). After washing $(2 \times 5 \mathrm{~min}$.) with PBS containing $0.1 \%$ bovine serum albumin and $0.01 \%$ sodium azide (PBSA) the cells were pelleted, the supernatant volume was reduced to approximately $50 \mu \mathrm{l}$ and the suspension was incubated with $5 \mu \mathrm{l}$ of fluorescein conjugated $\mathrm{F}(\mathrm{ab})_{2}$ fragment goat anti-human immunoglobulins (IgA, IgG, IgM) (Cappel Laboratories, Cochranville, USA) for 30 minutes at $0^{\circ} \mathrm{C}$. Sera positive in this assay were subsequently tested again to determine the immunoglobulin class. For this purpose monospecific fluorescein labelled rabbit antisera against human IgG, IgM and IgA were used (Cappel Laboratories, Cochranville, USA). After washing in PBSA ( $2 \times 5 \mathrm{~min}$.) the cells were mounted on slides and visually read using a Zeiss fluorescence microscope with epi-illuminator. Liver cell specificity of reactive testsera was studied by incubation of positive and negative sera on human breast cancer cells, colonic cancer cells and on fibroblasts as described previously (de Koning, in press). As negative control PLC/PRF/5 cells were incubated with the sera of 10 normal individuals, followed by fluorescein conjugated $\mathrm{F}(\mathrm{ab})_{2}$ goat anti-human immunoglobulin.

\subsubsection{Flowcytometry}

Samples were analysed on a FACS IV Cell Sorter (Becton and Dickinson, Sunnyvale, CA) equipped with a 2 W Argon ion laser (Spectra Physics, 164-01), operating at 488 $\mathrm{nm}$. Gates were set on forward and right angle light scatter to exclude dead cells and cell clumps. Fluorescence histograms of 2500 cells were recorded on a log scale ( 40 channels being one decade). The relative fluorescence intensity (RFI) was calculated according to the equation $\mathrm{RFI}=10^{x}$, where $\mathrm{x}$ is:

PFC* (Sample) - PFC (negative control)

40

The mean RFI and the standard deviation for the control sera were calculated for each immunoglobulin class.

A sample was considered positive when exceeding the $95 \%$ confidence level, which

* $\mathrm{PF}^{2} \mathrm{C}=$ peak fluorescence channel. 


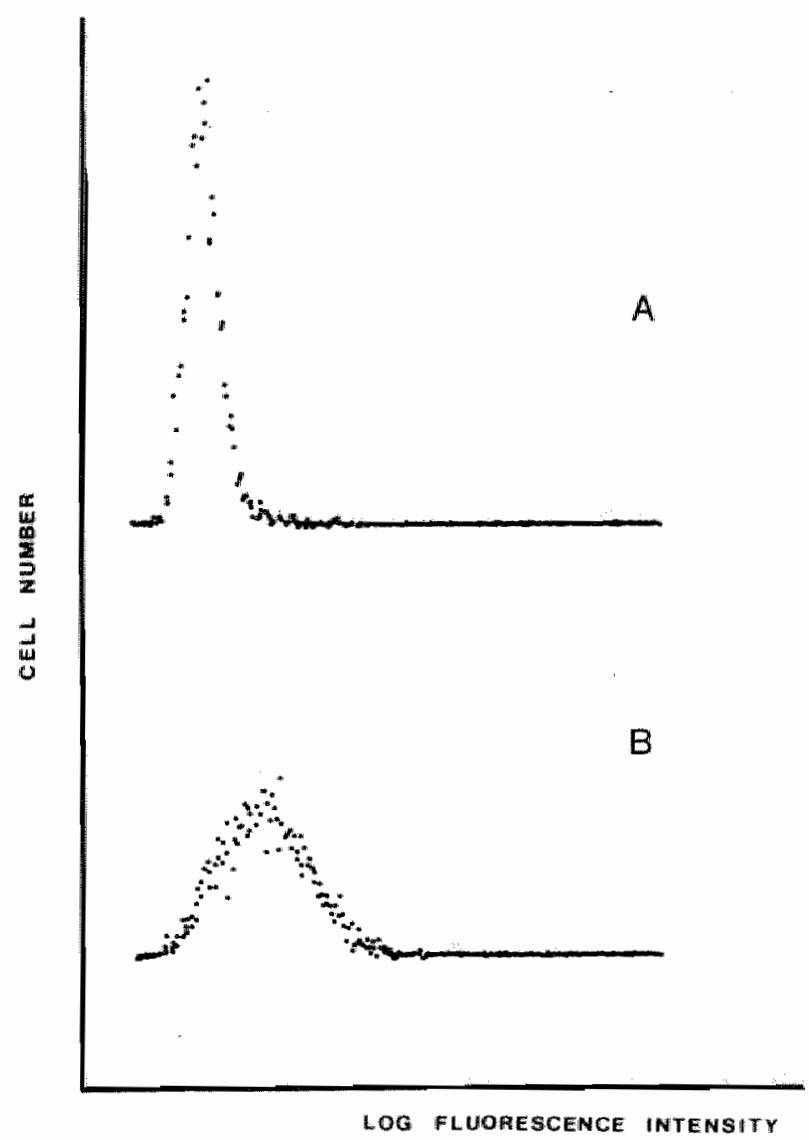

Figure 2: Membrane fluorescence distribution of PLC/PRF/5 cells stained with control serum (top) and a positive test serum (patient with sclerosing cholangitis) (bottom).

Note: the shift towards higher fluorescence intensity of the test serum.

for $\operatorname{IgG}, \operatorname{IgM}$ and $\operatorname{IgA}$ amounted successively $1.5,1.6$ and 1.5 . The number of positive cells was not used as a parameter to distinguish between positive and negative sera, because this appeared to be dependent on the quality of the cell suspension.

\subsubsection{Results}

Positive sera in the PLC/PRF/5 cell assay usually showed a microgranular to linear surface immunofluorescence staining pattern in all of the various liver diseases (Figure 1). With the immunoglobulin class specific antisera the immunofluorescence patterns were identical. The normal control sera were consistently negative. In Table 1 the results of the conventional LMA assay and of the PLC/PRF/5 cell assay are summarized for each category of inflammatory liver disease. With the con- 

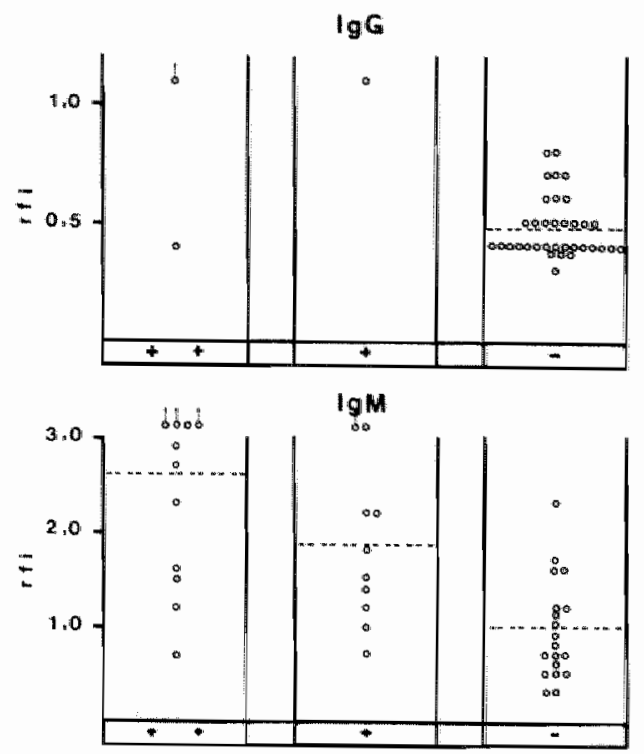

$\lg A$

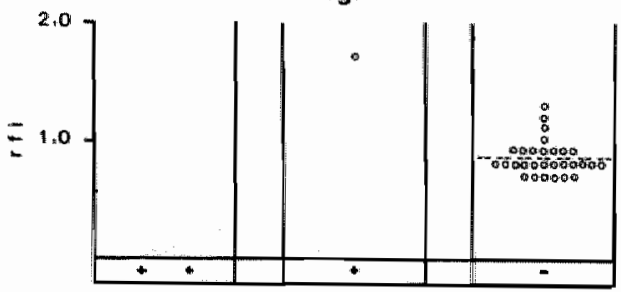

microsconle reading

Figure 3: Diagram showing relation between microscopic reading and relative fluorescence intensity (RFI) values for each immunoglobulin class in the PLC/PRF/5 cell assay.

Legends: -.... = mean RFI.

ventional LMA assay positive sera occurred only in patients with $\mathrm{PBC}$ and autoimmune chronic active liver disease. In the PLC/PRF/5/cell assay positive serum samples occurred in all disease categories with the exception of drug induced liver disease. Five sera appeared to be positive with the Ausab test. Only 1 out of 15 sera of patients with chronic active hepatitis $B$ and 2 out of 5 sera of patients with acute viral hepatitis reacted with PLC/PRF/5 cells and were negative with the conventional LMA assay and the Ausab test. Two samples of patients with autoimmune chronic liver disease, reactive with the PLC/PRF/5 cell assay, appeared to be positive with the Ausab test. The highest number of samples, positive with the PLC/PRF/5 cell assay, occurred in autoimmune chronic active liver disease.

Flowcytometric analysis was performed on all serum samples tested in the PLC/ PRF/5 cell assay. A typical flowcytometric reading, consisting of a fluorescence 
histogram of 2500 cells recorded on a logarithmic fluorescence intensity scale is shown in Figure 2. The plots in Figure 3 show the correlation between the results of fluorescence microscopic reading and the RFI values for all three immunoglobulin classes. As expected, a negative microscopic reading usually was parallelled by a low RFI value, whereas a positive microscopic observation generally corresponded with a high RFI value. In some cases, however, positive samples showed a low RFI value and vice versa.

Table 2 summarizes the immunoglobulin class patterns of PLC/PRF/5 cell reactive sera as determined by microscopic reading and RFI value. RFI values confirmed in general the results of the microscopic reading.

We found a very high prevalence of IgM antibodies ( 22 out of 25 positive samples i.e. $88 \%$ ). In alcoholic cirrhosis one sample with an IgA antibody was detected. In sclerosing cholangitis one serum with an IgG antibody occurred. This serum was negative in the Ausab test. A consistent and characteristic immunoglobulin class could not be established for any of the investigated disease categories. No reactive serum sample showed more than one immunoglobulin class in both assays.

\subsubsection{Discussion}

Hopf (1976) was the first to show that incubation of rabbit hepatocyte suspensions with sera of some patients with inflammatory liver disease results in a linear membrane immunofluorescence pattern. Therefore this finding shows that antibodies against liver membrane antigens occasionally occur in inflammatory liver disease. Common antigenic determinants on rabbit and human hepatocytes have been found (Meyer zum Büschenfelde, 1979). Assuming that some human antibodies might react exclusively with antigens specific for human hepatocytes it would seem appropriate to perform tests for such antibodies on human hepatocytes. Scarcity or even inavailability of normal human hepatocytes, however, precludes the regular use of these cells in routine clinical tests. As an alternative we have proposed to use the well differentiated human hepatocellular carcinoma cell line (PLC/PRF/5) for the same purpose. Our initial results were rather promising in showing a high level of concordance between the results of the conventional assay on rabbit hepatocytes and the experimental assay on PLC/PRF/5 cells (de Koning, in press).

In the present study a larger number of sera was studied and we also included an analysis of immunoglobulin class and of HBsAb. In agreement with earlier observations of Hopf (1976) and Tage Jensen (1977), in a relatively high number of cases of only PBC and autoimmune CALD liver membrane antibodies were detected with the conventional assay (Table 1). Other investigators, however, have shown that this phenomenon is by no means specific for these diseases (Schuurman, 1982; Meliconi, 1983b). In contrast to our preliminary report (de Koning, in press) we observed more positive sera with the PLC/PRF/5 cell assay than with the conventional rabbit hepatocyte assay: 25 versus 12 (Table 1). Close analysis of our data even shows that only 5 of the 
Table 1. Frequency of membrane reactive antibodies in the sera of patients with acute or chronic inflammatory liver disease applying the conventional rabbit hepatocyte assay and the PLC/PRF/5 cell assay.

Pat. Number of positive sera

Diseases

Alcoholic CLD*

$\mathrm{PBC}$

$\mathrm{HB}-\mathrm{CLD}$

IA - CLD

Cryptogenic cirrhosis

Acute viral hepatitis

Drug induced LD

Sclerosing cholangitis

Total

\section{N}

15

15

15

22

5

5

9

5

91
Rabbit hepatocytes

PLC/PRE/5-cells

\section{Legends:}

$\begin{array}{ll}* & =\text { alcoholic cirrhosis and alcoholic hepatitis } \\ \text { PBC } & \text { = primary biliary cirrhosis } \\ \text { CLD } & \text { = chronic liver disease } \\ \text { HB } & =\text { hepatitis B } \\ \text { IA } & =\text { idiopathic autoimmune } \\ \text { LD } & =\text { liver disease } \\ \text { () } & =\text { HBsAb positive }\end{array}$

sera which were found positive in the PLC/PRF/5 cell assay were also positive in the conventional assay. All other 20 positive sera were negative in the conventional assay. Several explanations for the occurrence of a high number of LMA negative, PLC/PRF/5 cell assay positive sera should be considered. Firstly the possibility exists that anti-HLA antibodies are detected because PLC/PRF/5 cells show a pronounced expression of HLA antigens. A simple assay to exclude this possibility was not available. However, the fact that the majority of the PLC/PRF/5 cell reactive antibodies was of IgM class argues against this option. Secondly the possibility exists that antibodies against hepatitis $\mathrm{B}$ surface antigen (HBsAb) are detected because PLC/PRF/5 cells express HBsAg. Indeed 5 out of the 20 sera were HBsAb positive. Consequently 15 sera were exclusively positive with the PLC/PRF/5 cell assay. We therefore postulate that in our assay antibodies specific for PLC/PRF/ 5 cells are detected. Control experiments, employing human normal and cancer cell lines of non-hepatocellular origin and normal human sera, support this contention. Conceivably in the PLC/PRF/5 cell assay species-specific liver membrane reactive antibodies are detected. Such a hitherto unrecognized category of antibodies could account for the difference between the immunofluorescence patterns in the conventional and the 
PLC/PRF/5 cell assay: whereas in the conventional assay only linear membrane immunofluorescence was observed, in the PLC/PRF/5 cell assay a mixture of microgranular and linear staining was noted. A similar staining pattern was detected in many sera by Wiedmann (1984) in a rat hepatocyte assay. When this pattern occurred he found incomplete correlation between immunofluorescence and a radiometric assay. It is quite conceivable that similar autoantibodies which in our PLC/PRF/5 cell test induced the granular immunofluorescence, are responsible for the PLC/PRF/5 cell reactivity in the sera which were negative with the conventional rabbit hepatocyte assay.

An unexpected result, given the close agreement in our preliminary report, was the occurrence of a significant number of sera which were positive in the conventional assay but negative in the PLC/PRF/5 cell assay. In the explanation of this finding several factors should be taken into account. Firstly it is conceivable that the procedure of harvesting of PLC/PRF/5 cells results in stripping of surface antigens. Reconstitution of the cells during a brief period of suspension culture after harvesting might alleviate such a problem. Secondly, although PLC/PRF/5 cells are derived from human hepatocytes their neoplastic nature may have resulted in an altered display of surface membrane antigens. Taken together our findings we suggest that the conventional assay and the PLC/PRF/5 cell assay may be complementary methods, which allow the detection of a wider spectrum of antibodies against liver membrane antigens than either assay alone. Further studies are needed to characterize the antigens detected by these antibodies, and studies, comparing clinical and serological information with antibody patterns, will be needed for a complete understanding of (1) the significance of these tests as a diagnostic tool and (2) the role of these antibodies in the pathogenesis of inflammatory liver disease.

As is indicated in Table 2 predominantly $\operatorname{IgM}$ antibodies were found in the tested sera. This observation is in line with those of Schuurman (1982) who used rabbit hepatocytes as substrate. Similarly, Wiedman (1984) also found predominantly IgM antibodies in a radiometric assay on rat hepatocytes. A unique immunoglobulin class pattern could not be identified for the different inflammatory liver diseases. This points to heterogeneity in the membrane antigens involved in the inflammatory reaction and in the pattern of humoral immune response within and between each disease category. The heterogeneity in immunoglobulin classes may be regarded as complementary to the heterogeneity with regard to PLC/PRF/ 5 cell reactive antibodies: only in a limited number of cases were such antibodies detected. Using the conventional assay, other investigators were unable to identify LMA in all cases of various categories of inflammatory liver disease (Jensen, 1978; Schuurman, 1982). These observations suggest that LMA do not play an important role in the pathogenesis of inflammatory liver disease. This conclusion is in agreement with the data of Eggink (1984) who considers LMA to be an epiphenomenon, accompanying all forms of hepatocellular injury.

In one patient with alcoholic cirrhosis we detected an IgA-antibody reactive with 
Table 2: Frequency of PLC/PRF/5 cell reactive antibodies (IgG, IgM, IgA) in sera of patients with acute or chronic inflammatory liver disease as determined by microscopic reading and confirmed by flowcytometry.

\begin{tabular}{lcccc}
\hline & Pat. & \multicolumn{2}{c}{ Number of positive sera } \\
\hline Diseases & N & IgG & IgM & IgA \\
Alcoholic CLD* & 15 & - & 4 & 1 \\
PBC & 15 & - & 3 & - \\
HB - CLD & 15 & - & $3(2)$ & - \\
IA - CLD & 22 & $1(1)$ & $6(1)$ & - \\
Cryptogenic cirrhosis & 5 & - & 2 & - \\
Acute viral hepatitis & 5 & - & $3(1)$ & - \\
Drug induced LD & 9 & - & - & - \\
Sclerosing Cholangitis & 5 & 1 & 1 & - \\
& & & & \\
Total & 91 & 2 & 22 & 1 \\
\hline
\end{tabular}

Legends:"

$\begin{array}{ll}* & =\text { alcoholic cirrhosis and alcoholic hepatitis } \\ \text { PBC } & =\text { primary biliary cirrhosis } \\ \text { CLD } & =\text { chronic liver disease } \\ \text { HB } & =\text { hepatitis } \mathrm{B} \\ \text { IA } & =\text { idliopathic autoimmune } \\ \text { LD } & =\text { liver disease } \\ () & =\text { HBSAb positive }\end{array}$

PLC/PRF/ 5 cells. This finding corresponds with observations of IgA-LMA in alcoholic liver disease by Hopf (1978) and Wiedmann (1984).

We finally tested the possibility to quantify the assay by application of flowcytometry. As is indicated in Figure 3 a good correlation between relative fluorescence intensity and microscopic reading was found. However, in isolated cases discrepancies were found. It should be realized that visual reading is less sensitive than flowcytometry but has the advantage that the localization of the fluorescence can be taken into account. Hence visual reading and flowcytometry should not be used alone but complementary to each other.

Based on the presented data we conclude that the PLC/PRF/5 cell line provides an interesting and potentially important substrate for the detection of liver membrane antibodies. In addition flowcytometric analysis was shown to be a useful method for objectivation and quantification of immunofluorescence analysis of membrane reactive antibodies. Further studies will be necessary to identify the clinical significance of the PLC/PRF/5 cell assay as well as the nature of the involved membrane antigens, which would ultimately be of great value for the development of uniform diagnostic assays. 


\subsubsection{Summary}

Sera of 91 patients with various inflammatory liver diseases were tested on human hepatoma (PLC/PRF/5) cells in an indirect immunofluorescence assay and in the conventional way on rabbit liver cells. Thirty two sera showed liver membrane reactive antibodies. In the PLC/PRF/ 5 cell assay 25 serum samples contained membrane reactive antibodies. Five of the sera contained antibodies against hepatitis $B$ surface antigen (HBsAb). These were negative in the conventional method for the detection of liver membrane antibodies (LMA). The LMA assay was positive in 12 cases. The higher number of positive sera in the PLC/PRF/5 cell assay may indicate the presence of species-specific liver membrane reactive antibodies. Seven sera were only positive in the conventional LMA assay. The results of the PLC/PRF/5 cell assay were read visually as well as recorded quantitatively by flowcytometry. A good correlation was found between the results obtained with these two different methods although some discrepancies occurred. It is concluded that PLC/PRF/5 cells may be used as a new substrate for the detection of liver membrane reactive antibodies. The clinical significance of this assay remains to be established. Flowcytometry offers a reliable additional method for objective and quantitative analysis of sera for the presence of liver membrane reactive antibodies. 


\subsubsection{REFERENCES}

1. Alexander, J.J., Bey, E.M., Geddes, E.W., Lecatsas, G.

Establishment of a continuously growing cell line fron primary carcinoma of the liver.

S.Afr.Med.J.: 50: 2124-2128, 1976.

2. Blijham, G.H., Schutte, B.

Flowcytometry in oncology: a review with emphasis on DNA flowcytometry in human solid tumors.

Neth.J.Med.; 26: 314-320, 1983.

3. Cochrane, A.M.G., Moussouros, A., Thompson, A.D.

Antibody dependent cell-mediated (K-cell) cytotoxicity against isolated hepatocytes in chronic active hepatitis.

Lancet; 1: $441-444,1976$

4. Eggink, H.F.

Liver membrane autoantibodies and the pathogenesis of liver diseases.

In: Cellular and humoral immune reactions in liver diseases: $67-83$.

Thesis, State University Groningen, 1984.

5. Hopf, U., Meyer zum Büschenfelde, K.H.

Studies on the pathogenesis of experimental chronic active hepatitis in rabbits. II. Demonstration of immunoglobulin on isolated hepatocytes.

Brit.J.Exp.Pathol.; 55: 509-513, 1974a.

6. Hopf, U., Meyer zum Büschenfelde, K.H., Freudenberg, J.

Liver specific antigens of different species. II. Localization of a membrane antigen at the cell surface of isolated hepatocytes.

Clin. Exp.Immunol.; 16: 117-124, $1974 \mathrm{~b}$.

7. Hopf, U., Arnold, W., Meyer zum Büschenfelde, K.H.

Studies on the pathogenesis of chronic inflammatory liwer diseases.

I. Membrane-fixed IgG on isolated hepatocytes from patients.

Clin.Exp.Immunol.; 22: 1-8, 1975.

8. Hopf, U., Meyer zum Büschenfelde, K.H., Arnold, W.

Detection of a liver membrane autoantibody in HBsAg negative chronic active hepatitis.

N.Engl.J.Med.; 294: 578-582, 1976.

9. Hopf, U., Brandzaleg, P., Hütteroth, T.H., Meyer zum Büschenfelde, K.H.

In vivo and in witro binding of $\lg A$ to the plasma membrane of hepatocytes.

Scand..J.Immunol.; 8: 543-549, 1978.

10. Jensen, D.M., McFarlane, 1.G., Portmann, B.S., Eddleston, A.L.W.F., Williams, R.

Detection of antibodies directed against a liver-specific membrane lipoprotein in patients with acute and chronic active hepatitis.

N.Engl.J.Med.; 299: 1-7, 1978.

11. Koning, R.W. de, Goodall, A., Varghese, Z., Thomas, H.C.

Hepatitis $\mathbb{B}$ virus and host cell membrane antigens on a primary hepatocellular carcinoma cell line. Liver; 4: 1-6, 1984.

12. Koning, R.W. de, Daemen, M., Schutte, B., Geertzen, H.G.M., Blijham, G.H., Bosman, F.T Immunofluorescence detection of liver cell membrane autoantibodies using PLC/PRF/S cells.

Eur.J.Clin.Invest.; in press.

13. Meliconi, R., Miglio, F., Stancari, M., Baraldini, M., Stefanini, G., Gasbarini, G.

Hepatocyte membrane-bound IgG and circulating liver-specific autoantibodies in chronic liver disease: relation to hepatitis $B$ virus serum markers and liwer histology.

Hepatology; 3: 155-161, $1983 a$.

14. Meliconi, R., Stancari, M., Garagnani, M., Baraldini, M., Stefanini, G.F., Miglio, F., Gasba.rini, $\mathrm{G}$.

Occurrence and significance of $\lg G$ liwer membrane autoantibodies (LMA) in chronic liver diseases of different aetiology.

Clin.Exp.Immunol; $51: 565-571,1983 \mathrm{~b}$.

15. Meyer zum Büschenfelde, K.H., Hütterath, T.H., Arnold, W., Hopf, U. 
Immunologie liver injury: The cole of hepatits $\mathrm{B}$ viral antigens and luver membrane antigens as tarigets.

In: Progress in Liver Diseases, VI: $407-424$.

Eda.: Popper, H. and Schaffrer, $F$.

Crune and Stratton, New York, 1979a.

16. Meyer zum Büsehenfelde, K.H., Manns, M., Hüteroth, T.H., Hopf, U., Arnold, W.

$\mathrm{LM}-\mathrm{Ag}$ and $\mathrm{LSP}$ - two different target antigens involved in the immunopathogenesis of chronic active hepatitis.

Clin. Exp.Immunol ; 37: 205-212, 19796.

17. Schuurman, H.J., Vogten, A.J.M., Schalm, S.W., Fevery, J.

Clinical evaluation of the liver cell membrane autoantibody assay.

Digestion; 23: 184-193, 1982.

18. Tage-Jensen, U., Arnold, W. Dietrichson, O., Hardi, F., Hopf, U., Meyer zum Büschenfelde, K.H., Nielseri, J.O.

Liver cell membrane autoantibody specific for inflammatory liver diseases.

Brit. Med.J.; : : 206-208, 1977 .

19. Wiedman, K.H., Bartholemew, T.C.,Brown, D.J.C., Thomas, H.C.

Liver membrame antibodies detected by immunoradiometric assay in acute and chronic virusinduced and ato-immune liver disease.

Hepatology; 4: 199-204, 1984. 


\section{CHAPTER VI}

\section{General discussion}

\subsection{LIVER MEMBRANE ANTIGENS. CURRENT STATUS}

Membrane antigens can be defined as macromolecules which are integrated in the cellular plasma membrane and are capable of eliciting an inmune response. These membrane associated macromolecules are important mediators in the regulation of the functions of cells. They can be cell surface receptors for hormones and neurotransmittors (for review see: MacKay, 1982; De Baets, 1984). They can be receptors for humoral or cellular components of the immune system (Roitt, 1980; Reinhertz, 1980). They are often species-specific or even specific for each individual (HLAantigens) and as such they play an important role in the recognition of 'non-self' and consequently in graft rejection.

The knowledge of the antigenic composition of the plasma membrane of normal hepatocytes is limited, partly due to difficulties in maintaining isolated hepatocytes in culture. HLA-A, B and C glycoproteins are sparsely displayed on hepatocytes in comparison to other cells in the liver such as the bile ductular, Kupffer and endotheliall cells (Thomas, 1982). As a target antigen for immune reactions liver specific lipoprotein has been relatively well characterized so far (Meyer zum Büschenfelde, 1984). Pathological alterations of the cell often lead to quantitative and/or qualitative changes in membrame antigens. For example in rejection of liver transplants bileduct damage occurs and HLA-DR antigens can be found on ductular cells (Takacs, 1983). Recently aberrant expression of HLA-DR antigens was reported on bileduct epithelium in primary biliary cirrhosis (Ballardini, 1984). Another example is expression of viral antigens subsequent to viral infection (Zeng, 1983). Membrane antigens can be the target of immune reactions: they allow the immune system to identify and eliminate abnormal cells. Elimination of neoantigen carrying cells results in healing, whereas inadequate elimination results in chronic disease. In autoimmune disease inappropriate immune reactions occur against antigens on or even in normal cells. Autoimmune diseases can be 'organ-specific', (e.g. Hashimoto's disease), but also 'non-organ specific' with lesions as well as autoantibodies occurring in different organs (e.g. systemic lupus erythematosus). In inflammatory liver diseases ummunologic factors are thought to be involved in the pathogenesis of hepatocellular necrosis and the progression of some cases of acute hepatitis to chronic hepatitis and cirrhosis. Which role humoral and cellular immune-mechanisms, acting against natural or neoantigens on the liver cell membrane, exactly play in the pathogenesis of inflammatory liver disease has not yet been clarified unequivocally. Also unsolved is the question how different etiologic factors activate different immunologic pathways to produce the same pattern of cellular injury. Although the presence of liver membrane anti-bodies does 
not necessarily imply any pathogenetic significance, their detection can be of value for diagnostic purposes and may serve as a guide for therapeutic interventions. Membrane antigens probably play an important role in neoplasia. Expression of tumour associated antigens (TAA) opens the possibility for a line of defence of the body against the development of cancer. From a clinical point of view tumour associated antigens are of significant interest: they may allow early detection (in vivo or in vitro) of the neoplastic phenotype and may serve as targets for antibody mediated therapy (Editorial Lancet, 1981). Initial attempts to detect tumour associated antigens involved the production of antisera against injected tumour cells. Antibodies against antigens on normal cells, which also appear in abundance on tumour cells, interfered with potential tumour specificity. Thorough adsorption procedures had to be applied, after which the yield of potentially tumour specific antibodies has generally been found to be disappointingly low. The limitations of the conventional approach to the production of tumour specific antibodies, in combination with the possibility of low density and weak immunogenicity of tumour specific membrane antigens (assuming that these antigens do exist) can be overcome by the application of the hybridoma methodology for the production of monoclonal antibodies (McAbs) (Köhler and Milstein, 1975). The value of this technique for the generation of antibodies more or less specific for neoplastic cells has been demonstrated in numerous reports (for a review see Lennox, 1982). Identification by $\mathrm{McAb}(\mathrm{s})$ of tumour specific antigen(s) offers new perspectives for detection (imaging) and treatment (targetting) of cancer. In this thesis we have

1. characterized membrane antigens on a stable, well differentiated hepatocellular carcinoma cell line (PLC/PRF/5 or Alexander cell line)

2. attempted to identify tumour specific antigens on these cells, which could be useful for early tumour detection or for immunotherapy of primary hepatocellular carcinoma

3. evaluated the use of PLC/PRF/5 cells as a substrate for the detection of liver membrane antibodies in a variety of inflammatory liver diseases.

\subsection{MEMBRANE ANTIGENS ON PLC/PRF/5 CELLS}

In chapter II we have attempted to analyze the expression of a number of well characterized antigens on PLC/PRF/5 cells. Earlier observations (Lebwohl, 1981; Sakaguchi, 1983) demonstrated that liver specific lipoprotein occurs on PLC/PRF/5 cells. We found an increased density of HLA antigens on these cells. In addition to increased HLA density, expression of additional antigens at the A locus was found. Furthermore, the presence of $\mathrm{HB}$ viral surface antigens on the membrane of a majority of PLC/PRF/5 cells was confirmed. In some cells co-capping of HLA and HBsAg could be demonstrated, suggesting physical association of these antigens. Finally, PLC/PRF/5 cells were shown to express the OKT9 antigen.

Which mechanisms are responsible for the increased HLA density on PLC/PRF/5 
cells in comparison with normal hepatocytes is unknown. A similar finding was recently reported on hepatocytes in a subgroup of HBV infected patients (Montano, 1982). Hepatitis B virus has been considered as an important factor in the etiology of hepatocellular carcinoma. It is therefore conceivable that integration of the HBV genome in PLC/PRF/5 cellular DNA (Marion, 1980; Chakraborty, 1980; Edman, 1980) has a pivotal role in the increased HLA density as well as in the expression of additional antigens at the A locus. Our finding of the presence of the virus-coded HBs antigen in the membrane of a majority of PLC/PRF/ 5 cells is in agreement with the hypothesis that HBV may play a role in the abnormal HLA expression in these cells. Expression of the OKT9 antigen is not unique for PLC/PRF/5 cells: recent studies have demonstrated that this antigen is in fact the transferrin receptor which can also be demonstrated on normal hepatocytes. It has been well established that enhanced expression of this antigen is a characteristic of rapidly dividing cells, as is frequently the case in neoplasia (Greaves, 1981).

\subsection{INDUCTION OF POLYCLONAL AND MONOCLONAL ANTIBODIES AGAINST PLC/PRF/5 CELLS}

As we have mentioned before, the occurrence of tumour specific antigens on neoplastic hepatocytes would be of major importance for diagnostic and therapeutic purposes. We attempted to identify such antigens on PLC/PRF/5 cells through the induction of antibodies to these cells. Initially a conventional approach was chosen: polyclonal antibodies were induced in rabbits. As this approach did not provide unequivocal proof of the presence of tumour specific antigens we subsequently used the hybridoma methodology.

\subsubsection{Conventional approach.}

For many years the only available method to detect tumour antigens was the induction of xenogenic polycional antisera. The best example of an antigen identified in this way, is the carcinoembryonic antigen (CEA). This antigen was detected by an antiserum induced against colonic carcinoma, after adsorption with normal tissues. Lately it appeared to be not tumour specific (Rogers, 1983). In general, this approach was found to be unsuccessful. Gradually it was realized that strongly immunogenic normal tissue components might interfere with the development of an immune response against weakly immunogenic antigens of spontaneously occurring tumours. A possible solution to this problem was developed by Weiner (1972) who incubated tumour cells with a blocking antiserum directed against normal tissue antigens, prior to immunization.

Along these lines we developed an antiserum against PLC/PRF/5 cells (chapter IV). In an attempt to reduce the response of non-specific surface antigens on PLC/ 
PRF/5 cells, these antigens were masked by incubating the cells with an antiserum against normal human liver cells. Preincubated PLC/PRF/5 cells were used for immunization.

Purification of the obtained antiserum was attempted by extensive immune adsorption with HBsAg, human lymphocytes and liverhomogenates. After adsorption reactivity with hepatitis B viral antigens, human lymphocytes and hepatocytes was virtually absent. Low-affinity immunoreactivity with PLC/PRF/5 cells remained however. Reactivity was also observed with a hepatocellular carcinoma. Furthermore, crossreactivity with testicular and prostatic tissue as well as with ovarian and colonic carcinoma cells was demonstrated. These results illustrate the difficulties which are commonly encountered in the search for tumour specific antigens by conventional immunological techniques. The negative results can be explained in two ways. Firstly it is conceivable that tumour specific antigens do not exist. Given the fact that almost all of the antigens, which were initially regarded as tumour specific, after extensive studies appeared to occur also in normal tissues, such a conclusion would not at all be unrealistic. An alternative hypothesis is that tumour specific antigens do exist but are scarce and/or weakly immunogenic and will therefore not induce an immune response, or the low affinity antibodies which are produced escape detection with a conventional polyclonal antiserum in the currently available detection techniques.

\subsubsection{Hybridoma approach}

In chapter IV our attempts to generate monoclonal antibodies (McAbs) specific for hepatocellular carcinoma cells are described. As immunogen we applied PLC/ $\mathrm{PRF} / 5$ cells. Several hybridomas producing $\mathrm{McAbs}$ against various membrane antigens of this cell line were obtained. After six fusions only one monoclonal antibody (VI-196) was obtained which did not show cross-reactivity with a panel of viral and fetal antigens nor with neoplastic cell lines of non-hepatocellular origin nor with normal human and rat hepatocytes. Another McAb (VI-235) reacted also with normal human liver cells but showed no reactivity with the other cell types used for specificity testing. This $\mathrm{McAb}$ therefore appeared to react with an antigen occurring only on human (normal as well as neoplastic) hepatocytes. Another antibody (1-28) reacted only with hepatocytes of human as well as of rat origin. One McAb (VI-133) reacted with an antigen on bile canaliculi. Finally one McAb (VI-191) showed immunoreactivity with an epitope of the hepatitis $B$ surface antigen.

The McAb (VI-196) reacting with PLC/PRF/5 cells only was subsequently tested by immunofluorescence on frozen sections of six human hepatocellular carcinoma specimens. In this experiment no immunoreactivity with any of these specimens was detected. These results can be explained in two ways. Firstly, it is conceivable that the epitope detected by McAb VI-196 can be demonstrated only on vital cells: PLC/ $P R F / 5$ cells were used in a radiobinding test whereas the human hepatocellular carcinomas were used as frozen sections. Furthermore it cannot be excluded that our im- 
munofluorescence technique was not sufficiently sensitive to detect the antigen nor that the immunoreactivity of the antigen was reduced by fixation prior to immune incubation. Secondly, these results may be taken as an indication that different hepatocellular carcinomas express different antigens.

Other attempts to produce hepatocellular carcinoma specific McAbs were reported by Wiedmann (1983) who raised two McAbs (K2 and K3) exclusively directed against two different antigens expressed on PLC/PRF/5 cells. A third McAb (K1) appeared to react with many neoplastic cells, but also showed some binding to the secretory epithelium of normal breast and pancreas. All these results suggest that tumour specific antigens, if ever they exist, are only weakly immunogenic. In fact there is still considerable disagreement as to whether or not tumour specific antigens do exist. It has been thought that the hybridoma technique would solve this problem. Several reports indeed claimed the generation of McAbs specific for cancer cells. Invariably, however, sufficiently extensive specificity tests revealed cross-reactivities with nonneoplastic cells (Dippold, 1980; Arends, 1983; Pallesen, 1983). Truly tumour specific antigens in human neoplasms have not been reported as yet.

\subsubsection{Future prospects}

Although our attempts, as well as those of others, to detect antigens specific for hepatocellular carcinoma $(\mathrm{HCC})$ have not been very successful, further studies are warranted because generation of $\mathrm{HCC}$ monoclonal antibodies with a high specificity would provide interesting opportunities for new diagnostic and therapeutic approaches. Investigations in collaboration with others (Bassendine, 1982) on solid PLC/PRF/5 tumours in athymic mice may serve as an example. In this model of $\mathrm{HCC}$ it was shown that serum alpha-fetoprotein concentrations correlated well with the tumour mass. Therefore this animal model appeared to be highly suitable for efficacy testing of anti-hepatoma reagents. It was shown that growth of PLC/PRF/5 tumours was reduced after administration of native and ricin conjugated monoclonal antibodies to HBs antigen (Oladapo, 1984).

Against the background of intercellular heterogeneity of antigen expression in hepatocellular carcinoma a combination of anti-hepatoma monoclonal antibodies may have to be applied in in-vivo drug-targetting or radioimaging experiments. In this context it should be realized that variability in antigen expression on cancer cells may not only be static but also dynamic, e.g. modulation of antigen expression in relation to the functional state of the cells (Boyse, 1967; Black, 1980). Further studies on cultured PLC/PRF/5 cells or on solid PLC/PRF/5 tumours induced in athymic mice may contribute to our understanding of these phenomena, which are of paramount importance in the development of new diagnostic and therapeutic approaches to the HCC problem. 


\subsection{ANTIBODIES AGAINST HEPATOCELLULAR MEMBRANE ANTIGENS}

\subsubsection{Established antibodies and liver injury}

It is quite evident that the immune system plays an important role in inflammatory liver diseases. As the interaction between hepatocytes and immunocompetent cells will always be mediated by plasma membrane components, the study of these components is of interest. In earlier studies the occurrence of autoantibodies in hepatitis $\mathbb{B}$ negative chronic hepatitis was established. These antibodies are not organ-specific and appear to be directed against cytoplasmic antigens. Their occurrence is believed to be an epiphenomenon secondary to liver cell destruction.

In the last decade autoantibodies specific for hepatocytes have been discovered. These antibodies have been shown to bind exclusively to antigens on the hepatocellular plasma membrane. The first of these antigens was liver specific protein (LSP), which was detected by autoantibodies showing a granular membrane fluorescence pattern on hepatocytes only (Meyer zum Büschenfelde, 1972; McFarlane, 1977). LSP appeared to have a complex antigenic structure with species-specific as well as species-nonspecific determinants (Manns, 1980a; Lambert, 1984) and organ specific as well as organ non-specific antigenic determinants (Behrens, 1979; Riisom, 1983; Murakami, 1984). Autoantibodies against LSP can be detected in different forms of chronic hepatitis as well as in autoimmune diseases which do not primarily affect the liver (Gerber, 1980; Manns, 1980b).

Subsequent studies established the occurrence of specific hepatocyte antibodies showing a linear fluorescence pattern, which have been designated liver membrane antibodies (LMA) (Hopf, 1976). LMA have been detected in some cases of various types of acute and chronic hepatitis (Tage-Jensen, 1977; Schuurman, 1982; Meliconi, 1983a; Eggink, 1984). LMA cannot be absorbed by LSP, indicating that the LMAantigen is different from LSP (Meyer zum Büschenfelde, 1979).

No correlation was found between the presence of LMA and smooth muscle, antimitochondrial and antinuclear antibodies (Manns, 1980c) nor between LMA and antiLSP (Meliconi, 1983b). It has been suggested that LMA may be involved in the process of damage of periportal hepatocytes, which may be the initial lesion in piecemeal necrosis (Meyer zum Büschenfelde, 1980). Wiedmann (1984) found the highest titer of rat liver membrane reactive antibodies in chronic hepatitis with extensive piecemeal necrosis. On the other hand, Eggink (1984) found no correlation between the presence or absence of LMA in the serum and the number and phenotype of immune-effector cells in the follow-up of autoimmune chronic active liver disease (CALD). He concluded that most probably antibody dependent cell mediated cytotoxicity plays a role in the pathogenesis of CALD, but not involving LMA as target antibody. From the data presented by Meliconi (1983b) the conclusion can be drawn that membrane reactive antibodies, bound in vivo to hepatocytes, are produced by the B cells which are associated with piecemeal necrosis and that these are of a different specificity than LMA 
in the circulation. So far, a pathogenic role for liver membrane antibodies has not been established. However, these antibodies are important diagnostic matkers to discriminate autoimmune CALD from non-A, non-B CALD (Wiedmann, 1984), especially in view of therapeutic consequences.

\subsubsection{PLC/PRF/5 cells and liver membrane antibodies}

A limitation of the presently available assays for LMA is that they all use rabbit hepatocyte suspensions as test substrate. In such an assay only species cross-reactive antibodies can be detected. Knowing that PLC/PRF/5 cells are well differentiated hepatoma cells which share many characteristics, such as membrane antigens, enzyme systems and production of serum proteins, with human hepatocytes (Dodd, 1978; Gerber, 1981; Tabor, 1981; Alexander, 1982), we explored the possibility of using these cells as test substrate in an indirect immunofluorescence assay. In addition to visual reading, flowcytometric analysis was performed. In a pilot study the feasibility of this approach was studied. A close correlation was found between the results obtatned on visual reading with rabbit hepatocytes and PLC/PRF/5 cells as substrates. The results of visual reading and flowcytometric analysis of immunostained cell suspensions were largely confirmatory. Subsequently we tested sera of 91 patients with different types of acute and chronic hepatitis with the PLC/PRF/ 5 cell assay as well as with the conventional LMA assay. Of these sera 32 contained rabbit hepatocyte and/or PLC/PRF/5 cell reactive antibodies. In the PLC/PRF/5 cell assay 25 serum samples were positive, whereas with the conventional LMA assay only 12 positive samples were found. In $5 \mathrm{PLC} / \mathrm{PRF} / 5$ cell assay positive sera HBsAb was detected, which may have been responsible for the detected reactivity. It is tempting to speculate that in the other PLC/PRF/ 5 cell reactive, LMA negative sera the reactivity is due to the presence of species-specific liver membrane antibodies. In order to reach this conclusion, however, the possibility that the detected antibodies react with HLA antigens or other non-liver specific membrane antigens should be firmly excluded. Of the 12 positive sera in the conventional assay 7 were negative in the PLC/PRF/ 5 cell assay.

This finding may be an artefact, related to the trypsintechnique of harvesting of the PLC/PRF/ 5 cells which may lead to stripping of surface antigens. Alternatively some normal liver antigens may not be present on these neoplastic cells. The discrepancies between the results in the PLC/PRF/5 assay and those in the conventional assay reflect in many ways the variability of the findings in the various assays which have been reported in the literature. An important factor in the observed variability is probably the use of biological substrates such as rabbit or rat hepatocytes or PLC/ PRF/5 cells, which are inhomogeneous from a biochemical point of view. An essential prerequisite for the development of standardized and reproducible assays would be the availability of pure antigens. Assays on pure antigens would have the additional advantage of being quantitative. In this respect flowcytometry was found to be a useful addition because this technique adds a quantitative dimension to a previously qualitative assay. 


\subsection{CONCLUSIONS}

Based on the experimental work described in this thesis the following conclusions can be drawn.

1. Although PLC/PRF/5 cells resemble normal human hepatocytes, several quantitative and qualitative differences were found:

- increased density of HLA expression

- expression of additional antigens at the A locus

- HBsAg expression (partly in physical association with HLA)

- expression of the transferrin receptor.

2. A monoclonal antibody with a reactivity restricted to $\mathrm{PLC} / \mathrm{PRF} / 5$ cells was obtained.

3. PLC/PRF/5 cells were found to be a suitable substrate for the detection of liver membrane reactive antibodies.

However, the PLC/PRF/ 5 cell test is not congruent with the established LMA assay. Additional studies will be necessary to explore fully the value of this test for the detection of liver membrane antibodies. 


\subsection{REFERENCES}

1. Alexander, J.J., Merwe, Ch.F, van der, Saunders, R.M., McElligott, S.E., Desmyter, J.

A comparison between in vitro experiments with a hepatoma cell line and in vivo studies. Hepatology; 2: $92 s-96 s, 1982$.

2. Arends, J.W., Verstijnen C., Bosman, F.T., Hilgers, J., Steplewski, Z.

Distribution of monoclonal antibody-defined monosialoganglioside in normal and cancerous human tissues: an inmunoperoxidase study.

Hybridoma; 2: $219-229,1983$.

3. De Baets, M.H.

Autoimmunity to cell surface receptors.

Thesis, State University Limburg, 1984.

4. Ballardini, G., Mirakian, R., Bianchi, F.B., Pisi, E., Doniach, D., Bottazzo, G.F.

Aberrant expression of HLA-DR antigens on bileduct epithelium in primary biliary cirrhosis: relevance to pathogenesis.

Lancet; II: 1009-1013, 1984.

5. Bassendine, M.F., Oladapo, J.M., Koning, R.W. de, Parmar, J., Thomas, H.C., Sherlock, S. Interferon therapy in hepatocellular carcinoma: studies in an animal model.

Hepatology; 2: 164, 1982.

6. Behrens, U.J., Parometto, F.

Studies on 'Liver-specific' antigens. 1. Evaluation of the liver specificity of LSP and LP-2.

Gastroenterol.; 77; 1045-1052, 1979.

7. Black, P.H.

Shedding from normal and cancer-cell surfaces.

N.Engl.J.Med.; 303: 1415-1416, 1980.

8. Boyse, E.A., Stockert, E., Old, L.J.

Modification of the antigenic structure of the cell membrane by thymus-leukaemia (TL) antibody. Proc.Natl.Acad.Sci.USA; 58: 954-957, 1967.

9. Chakraborty, P.R., Luiz Opazo, N., Shouval, D., Shafritz, D.A.

Identification of integrated hepatitis $B$ virus DNA and expression of wiral RNA in an HBsAg prom ducing human hepatocellular carcinoma cell line.

Nature; 286: 531-533, 1980.

10. Dippold, W.G., Lloyd, K.O., Li, L.T., Ikeda, H., Oettgen, H.F., Old, L.J.

Cell surface antigens of human malignant melanoma: definition of six antigenic systems with mouse monoclonal antibodies.

Proc.Natl.Acad.Sci.USA:77: 6114-6118, 1980.

11. Dodd, R., Grouaux, T., Bastiaans, $M$.

Biosynthesis of $\mathrm{HBsAg}$ and serum proteins by a human hepatoma cell line.

In: Viral Hepatitis; 698-709.

Eds.: Vyas, G., Cohen, S., Schmidt, R.

Franklin Instïtute Press, Philadelphia, 1978.

12. Edman, J.C., Gray, P., Valenzuela, P., Rail, L.B., Rutter, W.J.

Integration of hepatitis $B$ virus sequences and their expression in a human hepatoma cell.

Nature; 286: 535-538, 1980.

13. Editorial Lancet.

Monoclonal antibodies and cancer.

Lancet; 1: 421-423, 1981 .

14. Eggink, H.F.

Liver membrane autoantibodies and the pathogenesis of liwer diseases.

In: Cellular and humoral immune-reactions in liver diseases: 67-83.

Thesis, State University Groningen, 1984.

15. Gerber, M.A., Lebwohl, N., Thung, S.

Liver-specific protein: how specific is it?

In: Frontiers in Liwer Disease: 139-143.

Eds.: Berk and Chalmers, 1980. 
16. Gerben, M.A., Garfinkel, E., Hirschman, S.Z., Thung, S.N., Panagiotatos, T.

Immune and enzyme histochemical studies of a human hepatocellular carcinoma cell line producing hepatitis $\mathrm{B}$ surface antigers.

J.Immunol.; 126: 1085-1089, 1981.

17. Greaves, M., Delia, D., Sutherland, R.

Expression of the OKT monoclonal antibody defined antigenic determinants in malignancy.

Int. J. Immunopharmacol; 3: 283-300,1981.

18. Hopf, U., Meyer zum Büschenfelde, K.H., Arnold, W.

Detection of a liver-membrane autoantibody in HBsAg negative chronic active hepatitis.

N.Engl.J.Med.; 294: 578-582, 1976.

19. Köhler, $G$, Milstein, $C$.

Continuous culture of fixed cells secreting antibodies of predefined specificity.

Nature; 256: 495-497, 1975.

20. Lambert, K.J., Major, G.N., Welsh, C.J.R., Ryall, J.E., McFarlane, I.O., Williams, R.

Production and preliminary characterization of monoclonal antibodies to human liver-specific lipoprotein (LSP).

Liver; $4: 122-127,1984$.

21. Lebwohl, N., Gerber, M.A.

Characterization and demonstration of human liwer-specific protein (LSP) and apo-LSP.

Clin.Exp.Immunol.; 46: 435-442, 1981 .

22. Lennox, E.S., Sikora, $K$.

Definition of human tumour antigens.

In: Monoclonal antibodies in Clinical Medicine: $111-128$.

Eds.: McMichael, A.J., Fabre, J.W.;

Academic Press, 1982.

23. McFarlane, I.G., Wojcicka, B., Zucka, A.M., Eddleston, A.L.W.F., Williams, R.

Purification and characterization of human liver specific membrane lipoprotein (LSP).

Clin.Exp.Immunol.; 27: 3811-390, 1977.

24. MacKay, I.R.

Cell surface receptors.

Springer Seminars in Immunopathology; 5: 4, 1982.

25. Manns, M., Meyer zum Büschenfelde, K.H., Hütteroth, T.H., Hopf, U.

The liver specific protein: Evidence for species-specific and non-species-specific determinants.

J.Clin.Lab.Lmmunol.; 3: 9-13, 1980a.

26. Manns, M., Meyer zum Buischenfelde, K.H., Hess, $G$.

Autoantibodies against liver specific membrane lipoprotein in acute and chronic liver diseases: studies on organ-, species-, and diseases specificity.

Gut; $21: 955-961,1980 b$.

27. Manns, M., Meyer zum Buischenfelde, K.H., Hütteroth, T.H., Hess, G.

Detection and characterization of liver membrane autoantibodies in chronic active hepatitis by a solid-phase radioimmunoassay.

Clin.Exp.Immunol.; 42: 263-272, 1980c.

28. Marion, P.L., Salazar, F.H., Alexander, J.J., Robinson, W.S.

Site of hepatitis B viral DNA in a human hepatocelluar carcinoma celli line.

J. Viroll.; 33: 795-806, 1980.

29. Meliconi, K., Stancari, M., Garagnani, M., Baraldini, M., Stefanini, G.F., Miglio, F., Gasbarrini, $\mathrm{G}$.

Occurrence and significance of IgG liver membrane autoantibodies (LMA) in chronic liver diseases of different aetiology.

Clin.Exp.limmunol.; 51: 565-571, 1983a.

30. Meliconi, R., Miglio, F., Stancari, M., Baraldini, M., Stefanini, G., Gasbarrini, G.

Hepatocyte membrane-bound IgG and circulating liver-specific autoantibodies in chronic liver disease: relation to hepatitis $B$ virus serum markers and liver histology.

Hepatology; 3: 155-161, 1983b.

31. Meyer zum Büschenfelde, K.H., Miesscher, P.A. 
Liver specific antigens. Purification and characterization.

Clin. Exp.Immunol.; 10: 89-102, 1972.

32. Meyer zum Büschenfelde, K.H., Manns, M., Hütteroth, T.H., Hopf, U., Armold, W.

LMAg and LSP - two different target antigens involved in the inmunopathogenesis of chronic active hepatitis?

Clin.Exp.Immunol.; 37: 205-212, 1979.

33. Meyer zum Büschenfelde, K.H., Hütteroth, T.H., Manns, M., Möller, B.

The role of liver membrane antigens as targets in autoimmune type liver diseases.

Springer Semin. Immunopathol,; 3: 297-315, 1980.

34. Meyer zum Büschenfelde, K.H., Manns, M.

Mechanisms of autoimmune liver disease.

Semin.Liver Dis.; 4: 26-35, 1984.

35. Montano, L., Miescher, G.C., Goodall, A.H., Wiedmann, K.H., Janossy, G., Thomas, H.C. Hepatitis B virus and HLA antigen display in the liver during chronic hepatitis B virus infection. Hepatology; 2; 557-561, 1982.

36. Murakami, H., Kuriki, J., Kakumu, S., Fukwi, K., Sakamoto, N.

The specificity of human liver membrane lipoprotein: studies with monoclonal antibodies.

Hepatology; 4: 192-198, 1984.

37. Oladapo, J.M., Goodall, A.H., Parmar, J., Koning, R.W. de, Brown, D., Thomas, H.C.

In vitro and in vivo cytotoxic activity of native and ricin conjugated monoclonal antibodies to $H B s$ antigen for Alexander primary liver cell carcinoma cells and tumours.

Gut; 25: 619-623, 1984.

38. Pallesen, G., Jepsen, F.L., Hastrup, J., Ipsen, A., Hvidberg, $N$.

Experience with the Oxford tumour marker (Cal) in serous fluids.

Lancet; 1: 1326, 1983.

39. Reinherz, E.L., Schlossmann, S. F.

Regulation of the immune response-induced and suppressor $T$ lymphocyte subsets in human beings. N.Engl.J.Med.; 303: 370-373, 1980.

40. Riisom, K., Diedericksen, H.

Demonstration of organ-nonspecific antigens in liver-specific protein.

Gastroenterol.; 85: 1271-1276, 1983.

41. Roitt, I.M.

Essential immunology.

Blackwell Scientific Publications, 4th Ed., 1980

42. Rogers, G.T.

Carcinoembryonic antigens and related glycoproteins: molecular aspects and specificity.

Biochem. Biophys.Acta; 695: 227-249, 1983.

43. Sakaguchi, $K$.

Hepatocyte plasma membrane antigens. I. Determination of antibodies bound to the hepatocyte plasma membrane by ${ }^{125}$ I-protein. A binding assay.

Gastroenterol.Jpn.; 18: 330-338, 1983 .

44. Schuurman, H.J., Vogten, A.J.M., Schalm, S.W., Fevery, J.

Clinical evaluation of the liver cell membrane autoantibody assay.

Digestion; 23: 184-193, 1982.

45. Tabor, E., Copeland, J.A., Mann, G.F., Howard, C.R., Skelly, J., Sroy, P., Zuckerman, A.J., Gerety, R.J.

Nondetection of infectious hepatitis B virus in a human hepatoma cell line producing hepatitis B surface antigen.

Intervirology; 15: 82-86, 1981 .

46. Tage-Jensen, U., Arnold, W., Dietrichison, O., Hardt, F., Hopf, U., Meyer zum Büschenfelde, K.H., Nielsen, J.O.

Liver cell membrane autoantibody specific for inflammatory liver diseases.

Brit.Med.J.; 1: 206-208, 1977.

47. Takacs, L., Szende, B., Monostori, E., Rot, A., Lapis, K., Szecseny, A., Ando, I.

Expression of HLA-DR antigens on bileduct cells of rejected liver transplant.

Lancet; 1: 1500, 193. 
48. Thomas, H.C., Montano, L., Goodall, A., Koning, R.W. de, Oladapo, J., Wiedmann, K.H. Immunological mechanisms in chronic hepatitis B virus infection.

Hepatology; 2: 1168-121S, 1982.

49. Weiner, R.S., Hubbard, I.D., Mardiney, M.R.

Production of tumour-specific antibody in the xenogeneic host: use of blocking antibody. J.Natl.Cancer Inst.; 49: 1063-1070, 1972.

50. Wiedmann, K.H., Trejdosiewicz, L.K., Thomas, H.C.

Identification of membrane antigens expressed on primary liver cancer (PLC) cells but not on normal untransformed hepatocytes (abstract).

Hepatology: 3: 865, 1983 .

51. Wiednann, K.H., Bartholemew, T.C., Brown, D.J.C., Thomas, H.C.

Liver membrane antibodies detected by immunoradiometric assay in acute and chronic virusinduced and antoimnune liver disease.

Hepatology; 4: 199-204, 1984.

52. Zeng, Y., Gong, C.H., Jan, M.G., Fun, E., Xhang, L.G. Li, H.Y.

Detection of Epstein Barr virus IgA/Ea antibody for diagnosis of nasopharyngeal carcimoma by immunoautoradiography.

Int. I.Cancer; 31: 599-601, 1983. 


\section{SUMMARY}

In this thesis the usefulness of PLC/PRF/ 5 cells, derived from a well differentiated human hepatocellular carcinoma, for studies of liver disease is explored. These studies focussed mainly on membrane antigens. After the identification of a number of well known antigens on PLC/PRF/5 cells, we attempted to induce polyclonal and monoclonal antibodies against these cells, looking for the emergence of hepatocellular carcinoma specific antibodies which might be useful for diagnosis or therapy. In a parallel series of experiments the usefulness of PLC/PRF/5 cells for the detection of liver membrane reactive antibodies was evaluated.

Chapter I contains a review of the literature of selected clinicopathological and cytopathological aspects of hepatocellular carcinoma $(\mathrm{HCC})$. It appears that $\mathrm{HCC}$ is heterogeneous from an epidemiological, etiological and pathological point of view. Problems related to diagnosis and screening are discussed. The results of the available therapeutic regimens were disappointing. Tumour specific antigens could be useful for the diagnosis and for follow-up evaluation of therapeutic procedures. Such antigens would also provide the opportunity to raise specific anti-tumour antibodies which could be conjugated with toxins such as ricin. From reviewing of the available literature it becomes clear that it is virtually impossible to raise tumour specific antibodies by conventional methods. The discovery of the monoclonal antibody ( $\mathrm{McAb}$ ) technique intensified the search for tumour specific antigenic determinants. This approach seems to be the only possible way to identify tumour specific antigens, which could then be used for diagnostic tests and therapeutic procedures of superior efficacy. The results of monoclonal antibody studies on other types of cancer justified moderate optimism.

In Chapter II the literature on liver membrane antibodies (LMA) in inflammatory liver disease is reviewed. Autoantibodies to cytoplasmic organ non-specific antigens have been shown to be of diagnostic value in inflammatory liver diseases. In the last decade autoantibodies reacting with liver cell membrane antigens were detected. These antigens were proven to be partly species-specific, partly species-non-specific. In the formation of liver membrane antibodies in inflammatory liver diseases probably multiple antigen systems play a part. This would explain the variability in the literature concerning the pathogenetic significance of LMA. In spite of their diversity, these antibodies have appeared to be of important diagnostic value.

In Chapter III the results of a study on the occurrence of various membrane antigens on PLC/PRF/5 cells are reported. Whereas on normal human hepatocytes HLA class I antigens are sparsely displayed, we detected intense expression of HLA class I antigens on the cell membrane of PLC/PRF/5 cells. We also found expression of virus coded hepatitis $\mathrm{B}$ surface antigen ( $\mathrm{HBsAg}$ ) in the membrane of a majority of the $\mathrm{PLC} / \mathrm{PRF} / 5$ cells. In line with data from the literature, it is suggested that integra- 
tion of the HBV genome in PLC/PRF/5 cellular DNA has a pivotal role in the increased HLA density as well as in the expression of additional antigens at the A locus. In a minority of cells the capping of HLA antigen resulted in cocapping of HBsAg. This observation suggests that these antigens may be physically associated in the cell membrane. The significance of this finding is not clear.

On PLC/PRF/ 5 cells we also found the OKT9 antigen, which is present on many rapidly dividing normal and malignantly transformed cells. Recent studies have demonstrated that the antigen is in fact the transferrin receptor, also present on normal hepatocytes. However, it has been established that rapidly dividing cells show enhanced expression of this receptor protein.

In Chapter IV attempts to induce antibodies against PLC/PRF/ 5 cells are reported. Conventional as well as hybridoma methods were applied. For the induction of polyclonal antibodies we attempted to reduce the response of non-specific surface antigens on PLC/PRF/ 5 cells by masking of these antigens through incubation with an antiserum against normal human liver cells. These incubated PLC/PRF/5 cells were used for immunization. Purification of the obtained antiserum was attempted by extensive immune adsorption with $\mathrm{HBsAg}$, human lymphocytes and liverhomogenates. After adsorption, immunoreactivity against hepatitis B viral antigens, human lymphocytes and hepatocytes was nearly absent. Low-affinity immunoreactivity with PLC/PRF/5 cells remained however. Reactivity was also observed with another hepatocellular carcinoma, but appeared to be predominantly cytoplasmic. Furthermore, cytoplasmic cross-reactivity with testicular and prostatic tissue as well as with ovarian and colonic carcinoma cells was demonstrated. This approach did not provide tumour specific antibodies which might be useful for diagnosis or therapy. We turned therefore to the hybridoma methodology. Several hybridomas producing monoclonal antibodies (McAb) against various membrane antigens on PLC/PRF/5 cells were obtained. After six fusions only one McAb (VI-196) remained which did not show crossreactivity with a panel of viral and fetal antigens neither with neoplastic cell lines of non-hepatocellular origin nor with normal human and rat hepatocytes. Testing by immunofluorescence on frozen sections of six human hepatocellular carcinoma specimens showed no immunoreactivity. This disappointing finding can be explained by insensitivity of the immunofluorescence technique on frozen sections, by reduction of the immunoreactivity of antigen(s) due to fixation of the sections or to antigenic heterogeneity of $\mathrm{HCC}$.

McAb VI-235 reacted with PLC/PRF/5 cells but also with normal human liver cells. However, no reactivity with the other cell types used for specificity testing was found. This $\mathrm{McAb}$ therefore appeared to react with an antigen occurring only on human (normal as well as neoplastic) hepatocytes. McAb I-28 reacted only with hepatocytes of human as well as of rat origin. McAb VI- 133 reacted with an antigen on bile canaliculi. Finally, McAb VI-191 showed immunoreactivity with an epitope of the hepatitis B surface antigen. Summarizing, out of six fusions we obtained one McAb with a PLC/PRF/5 cell restricted immunoreactivity. 
Chapter $V$ describes two studies concerning the use of PLC/PRF/5 cells for the detection of liver membrane antibodies in chronic inflammatory liver disease.

The first is a pilot study, evaluating the feasibility of an assay with PLC/PRF/ 5 cells as substrate for the detection of liver membrane reactive antibodies by immunofluorescence. Ten sera of patients with various types of chronic liver disease were tested in a conventional liver membrane antibody (LMA) assay on rabbit hepatocytes and tested again on PLC/PRF/5 cells. A close correlation was found between the immunofluorescence results obtained with the two different substrates. Visual reading of immunofluorescence preparations was compared with flowcytometric analysis of identically processed cell suspensions. With these different methods the results were mostly the same. It was concluded that PLC/PRF/5 cells could be a valuable new substrate for detection of liver membrane antibodies and that flowcytometry could be a valuable method for objective and quantitative analysis of the results.

In the second study the PLC/PRF/ 5 cell assay was tested by visual as well as flowcytometric reading on 91 sera of patients with various forms of chronic inflammatory liver disease. The immunoglobulin class of $\mathrm{PLC} / \mathrm{PRF} / 5$ cell reactive antibodies was determined. The same sera were also tested in a conventional LMA assay on rabbit hepatocytes. In the conventional assay 12 sera were positive. Only 5 of these sera were also positive in the PLC/PRF/5 cell assay. An additional 20 sera showed reactivity only on PLC/PRF/5 cells. Of these 20 sera 5 contained antibodies against HBsAg. In the remaining 15 sera mainly IgM antibodies reacted with PLC/PRF/5 cells. With the exception of drug induced hepatitis, positive samples were found in all disease categories. A positive correlation was found between visual reading and flowcytometric analysis.

It was concluded that in the PLC/PRF/5 cell assay antibodies are detected against antigens which do not occur on rabbit hepatocytes. Whether or not these antigens are relevant liver specific membrane antigens or, on the contrary, ubiquitous antigens such as HLA, remains to be established. These findings underline the need for further characterization of the antigens which are recognized by liver membrane antibodies. In Chapter $V I$ our results are discussed in the context of the literature. 


\section{SAMENVATTING}

In dit proefschrift wordt de bruikbaarheid van PLC/PRF/5 cellen voor studies betreffende leverpathologie nagegaan. Deze cellen zijn geïsoleerd uit een goed gedifferentieerd menselijk hepatoma. In eerste instantie werden een aantal bekende antigenen op PLC/PRF/5 cellen geidentificeerd. Vervolgens werden polyclonale en monoclonale antistoffen tegen PLC/PRF/5 cellen geproduceerd om daarmee hepatoma specifieke antistoffen te verkrijgen, die van diagnostisch en therapeutisch belang kunnen zijn. Tenslotte werd de bruikbaarheid van PLC/PRF/5 cellen wat betreft het opsporen van levermembraan reaktieve antistoffen geëvalueerd.

Hoofdstuk I geeft een literatuuroverzicht van enige geselecteerde klinisch pathologische en cytopathologische aspekten van hepatomen (Hepatocellulair Carcinoom, HCC). Hepatomen blijken in epidemiologisch, etiologisch en pathologisch opzicht heterogeen te zijn. Problemen ten aanzien van diagnostiek en screening worden besproken. De resultaten van de bestaande behandelingswijzen zijn pover.

Tumor-specifieke antigenen kunnen van nut zijn voor de diagnostiek en voor de evaluatie van therapie. Dergelijke antigenen zouden ook de mogelijkheid scheppen tumor-specifieke antistoffen te vervaardigen, waaraan toxinen, zoals ricine, verbonden kunnen worden. Uit literatuuronderzoek is gebleken, dat het zeer moeilijk is om met conventionele methoden tumor specifieke antistoffen te maken.

De ontdekking van de hybridoma techniek gaf een nieuwe impuls voor onderzoek naar tumor-specifieke antigene determinanten. Deze techniek lijkt de enige mogelijkheid om tumor-specifieke antigenen te identificeren en zodoende een doorbraak in diagnostiek en therapie van $\mathrm{HCC}$ te forceren. Resultaten, behaald met monoclonale antistoffen bij het bestuderen van andere tumoren, wettigden een gematigd optimisme.

In Hoofdstuk II wordt de literatuur over levermembraan antistoffen (LMA) bij verschillende hepatitiden besproken. Auto-antistoffen, gericht tegen niet-orgaan specifieke cytoplasma-antigenen, blijken waardevol te zijn bij de diagnostiek van leverontstekingen. Tijdens het afgelopen decennium zijn auto-antistoffen tegen levercelmembraanantigenen ontdekt. Deze antigenen bleken deels species-specifiek, deels species-aspecifiek te zijn. Waarschijnlijk spelen meerdere antigenen een rol bij het ontstaan van levermembraanantistoffen bij leverontstekingen. Dit kan een verklaring zijn voor de bestaande verschillen van inzicht betreffende het pathologisch belang van LMA. Niettegenstaande deze diversiteit zijn deze antistoffen van diagnostisch belang gebleken.

Hoofdstuk $I I I$ geeft de resultaten weer van een studie aangaande het voorkomen van membraanantigenen op de PLC/PRF/ 5 cel. We ontdekten een uitgesproken expressie van HLA klasse I antigenen op de PLC/PRF/5 celmembraan; dit in tegenstelling 
tot een geringe expressie op normale levercellen. Tevens werd het hepatitis B oppervlakte antigeen (HBsAg) op het membraan van een meerderheid van de PLC/PRF/5 cellen aangetroffen. In overeenstemming met literatuurgegevens wordt gesuggereerd, dat de integratie van het hepatitis B virus (HBV) genoom in het DNA van de PLC/ PRF/ 5 cel een centrale rol speelt bij de toegenomen HLA dichtheid, alsook bij de expressie van additionele antigenen ter hoogte van het A locus. Bij een klein percentage van de cellen resulteerde „,capping" van HLA in , cocapping" van HBsAg. Deze bevinding suggereert, dat deze antigenen struktureel met elkaar verbonden kunnen zijn in de celmembraan. De betekenis hiervan is vooralsnog niet duidelijk.

Ook het OKT9 antigeen bleek op de PLC/PRF/5 cel aanwezig. Eerder werd dit antigeen aangetroffen in verscheidene, snel delende, normale en kwaadaardig ontaarde cellijnen. Bij recent onderzoek bleek dit antigeen de transferrine receptor te zijn, die ook op normale levercellen wordt aangetroffen. Het bleek echter dat snel delende cellen in verhoogde mate dit receptor eiwit bevatten.

In Hoofdstuk IV worden pogingen beschreven om antistoffen tegen PLC/PRF/5 cellen te vervaardigen. Hierbij werd zowel van conventionele als van hybridisatie methoden gebruik gemaakt. We probeerden niet-specifieke oppervlakte antigenen te bedekken met antistoffen gericht tegen normale menselijke levercellen. 'Gemaskeerde' $\mathrm{PLC} / \mathrm{PRF} / 5$ cellen werden gebruikt om een konijn te immuniseren. Door uitgebreid adsorberen met $\mathrm{HBsAg}$, menselijke lymfocyten en lewerhomogenaten werd getracht een zo zuiver mogelijk antiserum te vervaardigen. Tegen de genoemde antigenen bleek na de adsorbtieprocedure nagenoeg geen immuunreactiviteit meer te bestaan. De PLC/PRF/5 cellen reageerden daarentegen nog steeds, zij het in mindere mate. Cytoplasma-aktiviteit was ook aanwezig in een ander hepatoom. Bovendien bleek kruisreaktiviteit aantoonbaar met testis- en prostaatweefsel én met ovarium- en coloncarcinoomcellen. Deze benaderingswijze bleek derhalve geen tumor-specifieke antistoffen op te leveren, die bruikbaar zijn bij diagnostiek of behandeling van $\mathrm{HCC}$. Vervolgens hebben we ons op de hybridisatie-techniek gericht. Er werden verscheidene hybridomata verkregen, die monoclonale antistoffen $(\mathrm{McAb})$ vormden tegen verscheidene membraanantigenen op PLC/PRF/ 5 cellen. Na 6 fusies hielden we én monoclonaal antistof, McAb VI-196, over, die niet kruisreageerde met een serie van virale en foetale antigenen noch met andere tumorcellijnen noch met normale menselijke levercellen of die van de rat. Er bleek ook geen reaktiviteit te bestaan bij immunofluorescentie onderzoek van vriescoupes van biopsieën van 6 verschillende menselijke hepatomen. Deze teleurstellende bevinding kan mogelijk verklaard worden door een te geringe gevoeligheid wan de gebruikte techniek. Ook kunnen antigenen door fixatie beschadigd zijn en kan heterogeniteit van $\mathrm{HCC}$ een rol gespeeld hebben.

$\mathrm{McAb}$ VI-235 reageerde alleen met PLC/PRF/5 cellen en met normale menselijke levercellen die voor het specificiteitsonderzoek werden gebruikt. Dit McAb lijkt derhalve te reageren met een antigeen dat uitsluitend op humane (normale en kwaadaardige) levercellen voorkomt. McAb I-28 reageerde alleen met levercellen van zowel de mens 
als de rat. Een McAb (VI-133) toonde een reaktie met een antigene determinant op galcanaliculi. McAb VI-191 reageerde met een epitoop van hepatitis B antigeen (HBsAg).

Samenvattend verkregen we bij 6 fusies één McAb met een reaktiepatroon dat beperkt is tot PLC/PRF/5 cellen.

In Hoofdstuk $V$ worden 2 studies weergegeven, die betrekking hebben op het gebruik van PLC/PRF/5 cellen bij het opsporen van levermembraan antistoffen bij leverontstekingen. Aanvankelijk werd in een oriënterend onderzoek van 10 testsera een nauwe relatie gevonden tussen de immunofluorescentie uitkomsten van de conventionele test waarbij konijnelevercellen werden gebruikt en de PLC/PRF/5 celtest.

Voorts bleken immunofluorescentiemicroscopie en flowcytometrie van gelijke celsuspensies nagenoeg dezelfde resultaten op te leveren.

Uit het bovenstaande werd geconcludeerd, dat PLC/PRF/5 cellen een waardevol nieuw substraat voor het opsporen van levermembraan-antistoffen kunnen vormen en dat flowcytometrie een aanwinst is door de mogelijkheid de fluorescentie-gegevens te objectiveren en kwantificeren.

In de tweede studie werden 91 sera van patiënten met verschillende leverontstekingen op het voorkomen van membraan-reaktieve antistoffen onderzocht middels de conventionele alsook de PLC/PRF/5 celtest. Twaalf sera waren positief met de conventionele test. Slechts 5 van deze waren ook positief met de PLC/PRF/ 5 celtest. Twintig sera waren alleen positief met de PLC/PRF/ 5 celmethode. Van deze 20 sera bleken er 5 antistoffen tegen $\mathrm{HBsAg}$ te bevatten. Het merendeel van de resterende 15 sera bleek IgM antistoffen te bevatten. Met uitzondering van medicamenteuze leverontstekingen werden positieve uitslagen gevonden bij alle onderzochte hepatitiden. Ook in deze studie werd een goede correlatie tussen microscopische beoordeling en flowcytometrisch onderzoek gevonden.

De conclusie is, dat met de PLC/PRF/5 celtest antistoffen worden gevonden tegen antigenen die niet voorkomen op konijnelevercellen. Of deze antigenen voor de pathologie relevante lever-specifieke membraanantigenen zijn of daarentegen aspecifieke, zoals HLA, moet nog nader bestudeerd worden. Deze bevindingen benadrukken het belang van verdere karakterisering van de antigenen die reageren met sera van patiënten met de onderscheiden vormen van hepatitis.

In Hoofdstuk VI worden onze resultaten in samenhang met die uit de literatuur besproken. 


\section{ACKNOWLEDGEMENTS}

The experiments on which this thesis is based were performed in the Medical Unit of the Royal Free Hospital, London (Head: Prof.Dame Sheila Sherlock) and in the Department of Pathology, University of Limburg, Maastricht (Head: Prof.dr. F.T. Bosman).

This study would never have been completed without the critical and stimulating support of Prof.dr. Fred Bosman. My sincere thanks are due to him for all the time and energy spent to reach the present level of this thesis.

I am indebted to Prof.dr.Harry Hulsmans, who introduced me into the field of internal medicine and supported my extraresidential undertakings, especially my fellowship in Prof.Sherlock's Department. His critical comments and useful suggestions improved the content of this manuscript.

The basic idea for this study originated largely from Prof. Howard Thomas, under whose creative supervision I spent two years as a research-fellow. He carefully reviewed the final manuscript and suggested some useful changes.

I owe a lot to Prof.dr. Hendrik Jan Houthoff, who made a critical analysis of the data in an early stage and suggested some additional research. He also reviewed the final manuscript with great care.

Dr. Geert Blijham was a valuable colleague during our residency in internal medicine. I am most grateful for his extensive, critical review of the manuscript.

Prof.dr. Loek Kater was willing to comment on the design of the studies.

Under the accurate and kind guidance of Dr. Alison Goodall I was able to build up my practical immunological experience.

For four months I enjoyed the enthusiasm of Dr. Math Daemen, who carefully conducted laboratory work for the first LMA study as research-fellow.

Dr. Riekie Geertzen (CLB, Amsterdam) was of great help in the studies comparing the conventional LMA assay with the PLC/PRF/5 assay.

I acknowledge gratefully the cooperation in the specificity testing of antitumour antibodies with Dr. Luis Montano and Dr. Karl Wiedmann in London, dr. Marius Nap (Groningen) and dr. Jan Willem Arends, whose expertise on liver pathology was invaluable at our collective microscopical evaluations of my liverbiopsies and who has been a reliable friend at all times.

Dr. Maggie Bassendine and Dr. Jytta Oladapo in London introduced me into the research on the PLC/PRF/5 tumour in nude mice.

I am indebted to Dr. George Janossy, who offered the facilities of his laboratory for my hybridoma studies.

Over the years Prof.dr. Johan Fevery (Louvain) was prepared to give careful advice on clinical and research issues. I am indebted to him, to Dr. Jan van Hattum 
(Utrecht) and to Dr. Roelof Janssens (Leiden) for providing well characterized testsera.

During my first two years in London Jaishree Parmar gave excellent technical support.

Margriet Pijls and Birgit Engelen produced many immunocytochemical sections. Edith van der Linden and Cees Verstijnen took care of cellcultures and nude mice and Ineke Bantjes (CLB, Amsterdam) performed the conventional LMA assay. Bert Schutte made flowcytometric analysis of cell preparations and produced dotplots for publications.

For the skillful preparation of the manuscript I feel much obliged to Tiny WoutersLenssen and especially to Mieke Haemers.

The microphotographs were produced by members of the medical photography department of the St.Annadal Hospital (Head: Cor Evers) and of the Canisius Wilhelmina Hospital (Tim Haagendoorn).

I feel very grateful to Dr. P.J.F. Dupuis, from whom I received a training as a general practitioner, which went beyond the standard professional level.

Much gratitude is owed to Dr.J. Coenegracht, whose own high standard as tutor was a good example during my residence in internal medicine.

I owe a great deal of my education in gastroenterology to Prof. Krentz (Aachen), Dr. Dereck Jewell and Dr. Roy Pounder (London).

I am very much indebted for my training in hepatology to Prof.dr. Jan de Groote (Louvain) and all the members of the Medical Unit of the Royal Free Hospital in London. I wish to express my sincere thanks to Prof. Dame Sheila Sherlack for her inspiring, exceptional tutorship.

To my colleagues Gerard Benraad, Jules Enneking, Roy Go, Bas van Nooten, Fred Roorda, Clemens Ruland, Martin Schuurman, Jacques van Turnhout and especially Sing Tan, I am grateful for the relief from several duties.

I owe a special acknowledgement to my parents, who provided the conditions for my personal and intellectual development.

Last but not least I would like to thank my wife Hyacinthe and my daughters Lidwine and Heleen for their cordial support and for enduring those frequent periods of physical and mental abscence. 


\section{CURRICULUM VITAE}

Name: Rudolf Willem de Koning

Born : 12-01-1950 in Zwijndrecht, the Netherlands.

1961 - 1967 : Secondary School (Gymnasium B), Christelijk Lyceum, Dordrecht 1967 - 1974 : Medical School, Erasmus University Rotterdam

1974 : Training for general practitioner by Dr. P.J.F. Dupuis (Erasmus University Rotterdam

1975 : Compulsory military service

1976 - 1980 : Resident in Internal Medicine, St.Annadal Hospital, Maastricht (Head: Dr. J. Coenegracht)

1980 - 1982 : Fellow to Prof.Dame Sheila Sherlock, Medical Unit, Royal Free Hospital, London, U.K.

1981 : Registration in Internal Medicine

1982 - 1984 : Chef de Clinique, Department of Internal Medicine, University of Limburg (Head: Dr. J. Coenegracht, successively Prof.dr. J.A. Flendrig)

Since 1-6-1984 Consultant physician and head of the Gastroenterology Section in the Canisius Wilhelmina Hospital, Nijmegen, The Netherlands. 